\title{
Site U1388
}

\author{
Expedition 339 Scientists $^{2}$
}

\section{Chapter contents}

Background and objectives. ......... 1

Operations..................

Lithostratigraphy.............. 3

Biostratigraphy ..............6

Paleomagnetism .............. 8

Physical properties ............. 9

Geochemistry .................. 11

Stratigraphic correlation........... 12

References.................. 13

Figures.................. 16

Tables..................... 55

\section{Background and objectives}

Integrated Ocean Drilling Program (IODP) Site U1388 $\left(36^{\circ} 16.142^{\prime} \mathrm{N} ; 6^{\circ} 47.648^{\prime} \mathrm{W}\right)$ is located on an extensive sandy sheeted drift of the proximal sector (Sector 1; proximal scour and ribbons sectors defined by Hernández-Molina et al., 2003, and Llave et al., 2007) of the contourite depositional system (CDS) close to the Gibraltar Gateway (Figs. F1, F2, F3). This site represents an opportunity for recovering part of the late Pliocene and Pleistocene succession close to the gateway in order to identify key paleoceanographic changes in Mediterranean Outflow Water (MOW) and to evaluate the influence of the gateway. Site U1388 is $6.5 \mathrm{~km}$ southwest of the oil company exploratory well MPC-1 (dry well), where samples older than Quaternary were recovered in 1982.

This sector is located in the southeastern area between Cádiz and the Strait of Gibraltar and is characterized by a smooth contourite terrace oriented alongslope between 500 and 800 meters below sea level (mbsl) (Figs. F1, F2; see also Fig. F15 in the "Expedition 339 summary" chapter [Expedition 339 Scientists, 2013a]). It was first described by Kenyon and Belderson (1973) and later by Nelson et al. (1993), Habgood (2002), and Habgood et al. (2003), all of whom consider it as the proximal part of the CDS. It is an extensive area ( $100 \mathrm{~km}$ long and $30 \mathrm{~km}$ wide) dominated by an abrasional surface with high backscatter intensity (Fig. F2).

Several erosive scour alignments with a northwest-southeast orientation, smooth V-shaped expression, and truncated reflectors are evident in seismic profiles (Fig. F4). In the northwest part of this sector, distinct depositional features at the surface include a sequence of longitudinal bedforms (also oriented northwestsoutheast), ripple marks, sand ribbons, and sediment waves (Kenyon and Belderson, 1973; Nelson et al., 1993; Hanquiez et al., 2007).

Oil company data show an exceptionally thick ( $815 \mathrm{~m})$ sandy sheeted drift (see Fig. F15 in the "Expedition 339 summary" chapter [Expedition 339 Scientists, 2013a]) composed of sand-rich horizons that average $12-15 \mathrm{~m}$ in thickness (Buitrago et al., 2001) intercalated with finer grained sediments. In addition, a sand bank was identified by Akhmetzhanov et al. (2002) and Akhmetzhanov (2003) at the southeast boundary of this sector.

The Gibraltar Gateway has a very special role in MediterraneanAtlantic water mass exchange, which is associated with the high- 
est bottom current velocities known anywhere in the study region (nearly $300 \mathrm{~cm} / \mathrm{s}$ ). This is also one of the most important oceanic gateways worldwide, enabling overflow and circulation of MOW to the Atlantic Ocean (e.g., Serra, 2004; Legg et al., 2009; Serra et al., 2010). The proximal sector within the CDS of the Gulf of Cádiz results from MOW generating strong and turbulent bottom currents, which contour the slope between 300 and 1000 mbsl (Kenyon and Belderson, 1973; Habgood et al., 2003; Hernández-Molina et al., 2003, 2006, 2011). Its velocity decreases from a maximum of $240 \mathrm{~cm} / \mathrm{s}$ immediately west of the Gibraltar Gateway to $~ 75-100 \mathrm{~cm} / \mathrm{s}$ near the northern end of the Cádiz sand sheet (Fig. F5). Beneath the highest velocity zone there is a broad abrasional surface and erosive scours, but as current velocity decreases, sand ribbons and wave fields develop. MOW divides into an upper and lower core at the northwest end of this sector, as described by Madelain (1970).

\section{Objectives}

The major objective for Site U1388 was to recover a sedimentary contourite record for the late Pliocene to the Holocene deposited under the influence of the overflow of MOW close to the Gibraltar Gateway (Stow et al., 2011b). This record will allow us to investigate

- The influence of the Gibraltar Gateway through the Pliocene and Pleistocene,

- MOW paleoceanography and its global climate significance, and

- The effects of long- and short-term climate and sea level changes on the sediment architecture of the contourite drift.

Specific objectives for Site U1388 include

- Drilling through the sheeted drift succession and into late Pliocene sediments and hence dating the most important intervals for sandy contourite sedimentation in the Gulf of Cádiz;

- Evaluating the nature of change in the patterns of sedimentation and microfauna from the late Pliocene through the Holocene;

- Documenting the possible effects of the Gibraltar Gateway through the Pliocene and Pleistocene and hence determining the input variation of MOW influx;

- Reconstructing the main MOW paleoceanographic events for the Pliocene and Pleistocene and identifying the role of MOW in the dynamics of North Atlantic Deep Water;
- Focusing on the diagnostic criteria for sand-rich contourite deposits on sheeted drifts and the inferred environmental changes;

- Evaluating the correlation and influence of cold/ warm periods with MOW variation;

- Determining the sedimentary stacking pattern of the sandy sheeted drift in relation to changes in sea level and other forcing mechanisms, thereby determining the potential role of variations in cross-sectional area of the Gibraltar Gateway;

- Evaluating periods of sheeted drift construction, nondeposition (hiatuses), and erosion;

- Evaluating the sandy contourite deposition in relation to sea level variation; and

- Calibrating and therefore understanding the sedimentary cyclicity evident on the sandy contourite deposits, thereby characterizing their sedimentary expression and regional extent.

In addition to these objectives, improved knowledge of sand-rich contourite deposits will have significant implications, both in the establishment of a facies model for sandy contourites (Stow and Faugères, 2008; Viana, 2008) as well as in consideration of their potential as a future deepwater hydrocarbon exploration target (Buitrago et al., 2001; Llave et al., 2005; Akhmetzhanov et al., 2007; Viana et al., 2007; Viana, 2008; Stow et al., 2011a; Brackenridge et al., 2011).

\section{Operations}

The $55 \mathrm{nmi}$ transit from Site U1387 to Site U1388 (proposed Site GC-04D) was accomplished in $\sim 5 \mathrm{~h}$ at an average speed of $11 \mathrm{kt}$. At $0745 \mathrm{~h}, 18$ December 2011 , the vessel was positioned on the new location.

The operations plan for Site U1388 called for advanced piston corer (APC)/extended core barrel (XCB)/rotary core barrel (RCB) coring in three holes and conducting downhole logging operations in Holes U1388B and U1388C. The first two holes were to be cored with the APC to refusal and then with the XCB to $\sim 350 \mathrm{mbsf}$. The third hole was to be cored with the RCB from 350 to 1300 meters below seafloor (mbsf). Ultimately, three holes were drilled (Table T1), but the coring objectives were not achieved because of hardware failure caused by a difficult sandy formation. In Hole U1388A, APC Core $339-\mathrm{U} 1388 \mathrm{~A}-1 \mathrm{H}$ advanced only $3.4 \mathrm{~m}$ (107.6\% recovery) because a thick sand layer at the sediment surface prevented the core from penetrating any further. Hole U1388B was cored using the XCB to 225.7 mbsf with $47.2 \%$ recovery. Hole U1388C was drilled 
without coring to $205 \mathrm{mbsf}$ and then cored using the RCB to 229 mbsf. Overall recovery at Site U1388 was $120.54 \mathrm{~m}$ (47.6\%): $3.64 \mathrm{~m}$ (107.6\% recovery) with the APC, $106.54 \mathrm{~m}(47.2 \%$ recovery) with the XCB, and $10.36 \mathrm{~m}$ ( $43.17 \%$ recovery) with the $\mathrm{RCB}$. The site was terminated earlier than planned because of formation instability.

\section{Hole U1388A}

An APC/XCB bottom-hole assembly (BHA) with a 978 inch polycrystalline diamond bit, lockable float valve, seal bore drill collar, and nonmagnetic drill collar was assembled and deployed. Following a 1.3 $\mathrm{h}$ underwater camera survey of the seafloor over a 30 m grid pattern, Hole U1388A was spudded with the APC at $1500 \mathrm{~h}$. The calculated seafloor depth from the recovery of the first core was 675.1 meters below rig floor (mbrf; $663.6 \mathrm{mbsl}$ ), which was $0.7 \mathrm{~m}$ deeper than the corrected depth given by the precision depth recorder. The second attempt at a piston core appeared to be an incomplete stroke. The core winch operator spent $\sim 3 \mathrm{~h}$ attempting to recover the stuck core barrel. The Kinley cutter was deployed to cut the coring line above the sinker bars when it was not possible to jar off the core barrel. The only course of action remaining was to recover the drill string and extricate the core barrel on the surface. The drill string was retrieved by $2400 \mathrm{~h}, 18$ December. The reason why the core barrel couldn't be recovered was obvious; most of the BHA was full of sand that apparently "U-tubed" when the driller advanced into the formation to position the bit for the next piston core $(2 \mathrm{H})$.

\section{Hole U1388B}

The BHA was cleared of sand and deployed to 669.9 mbrf. The vessel offset $20 \mathrm{~m}$ east of the previous hole. The underwater camera displayed what appeared to be man-made debris on the seafloor and precipitated another $10 \mathrm{~m}$ offset to the east. The strategy for the second hole of the site was to core an $\mathrm{XCB}$ hole to depth and use the information acquired from that pilot hole to assess if and where the APC could be deployed in subsequent holes. The driller tagged seafloor at $674.4 \mathrm{mbrf}(662.9 \mathrm{mbsl})$ at $0645 \mathrm{~h}$. The camera system was recovered, and the top drive was picked up. Hole U1388B was spudded with the $\mathrm{XCB}$ at $0835 \mathrm{~h}, 19$ December, and advanced to 225.7 mbsf by 0745 h, 20 December. While coring this interval, extensive cutting shoe damage suggested that the distribution of fluid flow between the cutting shoe and the polycrystalline diamond bit was not optimum for this formation. Rather than continue coring in this fashion and considering that the objectives of this site were deeper in the formation,
XCB coring was terminated at $225.7 \mathrm{mbsf}$. The average recovery for this hole was $47.2 \%$. The driller pumped a $5 \mathrm{bbl}$ slug of heavy mud prior to making a connection for Cores 1X through 12X (110.9 mbsf) to avoid a recurrence of the sand backflowing into the BHA. A $20 \mathrm{bbl}$ sepiolite flush was made at 216.1 mbsf. The drill string was pulled clear of the seafloor at $0925 \mathrm{~h}$ and on deck at $1155 \mathrm{~h}, 20$ December.

\section{Hole U1388C}

A four-stand RCB BHA with a new CC-4 Rock Bit International bit and mechanical bit release was made up and run in to 668.0 mbrf. After a short underwater camera survey confirmed that the location of the hole was clear of debris, the driller tagged the seafloor at $674.0 \mathrm{mbrf}(662.5 \mathrm{mbsl})$. The underwater camera was recovered, the top drive was picked up, and Hole U1388C was spudded with the RCB at 1915 h, 20 December. The hole was washed to $205.0 \mathrm{mbsf}$, where rotary coring was initiated. At 119.8 and 167.6 mbsf, 20 bbl Hi-Vis mud sweeps were circulated. Rotary coring advanced from 205.0 to 229.0 mbsf, where the drill sting became firmly stuck in the formation with no rotation and limited circulation. The drill string required $1.5 \mathrm{~h}$ to free the pipe utilizing overpulls of as much as $120,000 \mathrm{lb}$ and adjusting rotary current limits as high as $1050 \mathrm{~A}$. Once the pipe came free, more mud (both Hi-Vis and $10.5 \mathrm{ppg}$ ) was pumped to clear out some of the sand that had collapsed on the BHA. The drill string was pulled free of the seafloor at $1330 \mathrm{~h}$ and on deck by $1725 \mathrm{~h}, 21 \mathrm{De}-$ cember. The formation was considered too unstable to safely core, and the decision was made to move to the next planned site of the expedition. Total time at Site U1388 was 3.2 days, which was 10 days less than the allotted time. The vessel departed for Site U1389 at 1730 h, 21 December.

\section{Lithostratigraphy}

Drilling at Site U1388 penetrated a $225 \mathrm{~m}$ thick sedimentary section with significant variations in recovery among the three holes drilled (Figs. F6, F7). The shipboard lithostratigraphic program involved detailed visual logging of all archive sections, visual assessment of sediment color, petrographic analysis of smear slides (no shipboard thin sections were created), and X-ray diffraction (XRD) analysis of 22 powdered bulk samples and 6 clay fraction samples. Bulk XRD samples generally were taken once per core, and the clay fractions of those samples were analyzed once per four cores. Sediment from Holes U1388A-U1388C was sampled regularly for smear slides during visual core descriptions. Hand-drawn logs showing the recovered sediment sequence, in- 
cluding the distribution and structure of bedding, are included in the DRAWLOG folder in "Supplementary material."

Total carbonate content of these cores, based on shipboard analyses, ranges from 18 to $30.1 \mathrm{wt} \%$, with an average of $25.1 \mathrm{wt} \%$ assuming that all inorganic carbon was calcium carbonate (Fig. F8). These results are consistent with abundances of biogenic and detrital carbonate estimated from smear slides, so lithologic names determined from smear slide analysis have been used without modification through this text, the accompanying summary diagrams, and the visual core description sheets.

The sediments recovered in all three holes at Site U1388 are considered to represent a single lithologic unit. Because of hole stability problems and the presence of sandy sediment, however, not all of Unit I was fully sampled. Following core recovery problems after Core 339-U1388A-1A (see "Operations"), Hole U1388B was spudded with the XCB and recovery was generally poor until Core 339-U1388B-12X. Drilling in Hole U1388C used rotary drilling to recover sediments that overlapped with the base of Hole U1388B.

The sediment at Site U1388 is classified as one lithologic unit (Fig. F7). Unit I is a Holocene to Pleistocene sequence (see "Biostratigraphy") with interbedded nannofossil mud, mud with biogenic carbonate, silty mud with biogenic carbonate, silty sand with biogenic carbonate, sandy silt with biogenic carbonate, and sand. The thickest sand bed $(3.64 \mathrm{~m})$ is at the sediment surface (all of Core 339U1388A-1H) and is primarily fine sand with shell fragments; however, grain size approaches coarse sand to granule-grade in horizons where shell fragments are common. Most of the coarser beds recovered deeper in the section are silty muds, muddy sands, and silty sands. These are predominantly medium to thick bedded with occasional very thick beds (the thickest observed is $\sim 7.5 \mathrm{~m}$ thick). In contrast, the finer sediments are muds with biogenic carbonate.

The character of sediment physical properties, including natural gamma radiation (NGR), magnetic susceptibility, color reflectance parameters, and density, records the distribution of these various lithologies and sediment components (see "Physical properties"). Characteristics of the sedimentary sequence cored at Site U1388, together with some of these additional properties, are summarized in Figure F9.

\section{Unit I description}

Intervals: $339-\mathrm{U} 1388 \mathrm{~A}-1 \mathrm{H}-1,0 \mathrm{~cm}$, through $1 \mathrm{H}-$ CC, $61 \mathrm{~cm}$; 339-U1388B-1H-1, $0 \mathrm{~cm}$, through
24X-CC, $36 \mathrm{~cm}$; 339-U1388C-2R-1, $0 \mathrm{~cm}$, through 4R-1, $88 \mathrm{~cm}$

Depths: Hole U1388A $=0-3.64$ mbsf (bottom of hole $[\mathrm{BOH}])$, Hole U1388B $=0-225.73 \mathrm{mbsf}$ $(\mathrm{BOH})$, Hole U1388C $=205-224.98 \mathrm{mbsf}(\mathrm{BOH})$

Age: Holocene-Pleistocene

\section{Lithologies and bedding}

The major lithologies in Unit I are silty mud with biogenic carbonate, silty sand with biogenic carbonate, and mud with biogenic carbonate. Secondary lithologies are calcareous sand and sand with biogenic carbonate; sandy silt and sandy mud, both with biogenic carbonate; and nannofossil mud and calcareous silty mud. Most of Unit I contains 10-25 wt $\%$ carbonate, although some coarser sandy layers contain $>25 \mathrm{wt} \%$ carbonate because of abundant shell fragments.

Uncertainty about the lithologies of the unrecovered intervals has implications for the ability to define lithologic units and subunits at Site U1388. Sandy beds (including calcareous sand, sand with biogenic carbonate, silty sand with biogenic carbonate, sandy silt with biogenic carbonate, and sandy mud with biogenic carbonate) and silty beds (including silty mud with biogenic carbonate) form $\sim 75 \%$ of the sediment recovered above $\sim 100$ mbsf and $\sim 25 \%$ of the sediment recovered below that level (Figs. F7, F10). However, the overall rate of sediment recovery was much lower above $\sim 100 \mathrm{mbsf}$, so the sandy and silty beds that were recovered average $15 \%-20 \%$ of the total depth intervals cored below $\sim 5$ mbsf. We attribute the poor recovery at this site to the use of XCB coring in unconsolidated sands, but note that our interpretation of the lithologic sequence would change if the unrecovered sediments above 100 mbsf are different from the sediments recovered by coring in that interval. Sandy units are quite difficult to recover using the XCB because there is no closure on the bottom of the pipe, so this part of the section would be quite coarse if all unrecovered sediments above 100 mbsf are sandy. However, if all the unrecovered sediment in this hole was mud (weakly consolidated muds are also difficult to recover using $\mathrm{XCB}$ coring), then the percentage of sandy and silty beds relative to total thickness cored would be nearly identical at $17.4 \%$ above 100 mbsf and $16.7 \%$ below 100 mbsf (Fig. F10). Although the latter may not be a likely scenario, we are forced to conclude that it is not possible to divide Unit I based on visual observations of the recovered sediment alone. Additional studies will be needed to determine whether Unit I can be further divided.

The coarsest bed in Unit I is the $\sim 3.64 \mathrm{~m}$ thick bed of fine sand recovered in Core 339-U1388A-1H. This 
bed has layers of coarse sand to granules, with shell debris, at intervals 339-U1388A-1H-1, 139-148 cm; $1 \mathrm{H}-2,111-116 \mathrm{~cm} ; 1 \mathrm{H}-3,0-13 \mathrm{~cm}$; and $1 \mathrm{H}-3,20-30$ $\mathrm{cm}$. Sediment in Holes U1388B and U1388C is not as coarse as that in Hole U1388A, with the coarsest beds in Holes U1388B and U1388C described as silty sand. As sampled in Holes U1388B and U1388C, Unit 1 predominantly is medium to thick bedded, with some coarse-grained beds as thick as $\sim 7.5 \mathrm{~m}$. The finer grained beds are muds with biogenic carbonate and range in thickness from $\sim 0.5$ to $>15 \mathrm{~m}$. The contacts between lithologies are generally gradational and bioturbated, although some of the coarser grained beds have sharp to erosional lower contacts.

\section{Structures and texture}

Only Core 339-U1388A-1H was recovered by APC. All cores in Hole U1388B were recovered by XCB and as such have been biscuited to some extent, thus obscuring sedimentary structures. Shell fragments are common in coarser grained layers, especially in many of the coarser beds (e.g., Sections 339-U1388B$7 \mathrm{X}-1 \mathrm{~A}$ and $339-\mathrm{U} 1388 \mathrm{~A}-1 \mathrm{H}-2 \mathrm{~A})$, perhaps related to the movement of large bedforms.

Normally graded and inversely graded beds are present in Unit I. Many of the coarser beds have gradational upper and lower contacts, exhibit bi-gradational bedding, and are considered to be of contourite origin. Figure F11 shows a typical silty contourite, $24 \mathrm{~cm}$ thick, in Section 339-U1388B$13 \mathrm{X}-3$. Another typical bi-gradational sequence is present in Core 339-U1388B-23X that is $\sim 3.5 \mathrm{~m}$ thick and also interpreted as a contourite. Other beds exhibit normal grading and sharp to erosional lower contacts (Fig. F12) and are interpreted as turbidites. Beds with inverse grading are also present (Figs. F13, F14, F15) and generally are medium to thick to very thick bedded. These reverse-graded beds exhibit a variety of upper and lower contacts, ranging from erosional to gradational. Because of this variability in contact type, the deposition of these beds is most likely a result of current activity. In general, the contacts between other beds also range from sharp to gradational and bioturbated, but it is not generally clear whether biscuiting had occurred at those contacts.

Parallel laminated sands are present in interval 339U1388B-20X-5, 50-105 cm (Fig. F16), formed by alternating lighter and darker laminations each 2-6 $\mathrm{mm}$ thick. The principal difference between the light and dark sand laminations appears to be a lower mud content in the light-colored sands. We interpret these as primary parallel laminations formed by currents, although the role of drilling disturbance in their formation is not known.
Deposits originating from sediment failure are also noted at this site. A possible debrite is identified at interval 339-U1388B-10X-2, 41-121 cm, and a possible slump is identified at interval 339-U1388B-24X5, 33-54 cm (Fig. F17). These deformed, thinly bedded sediments have inclined contacts between muddy and sandy intervals, as well as possible muddy intraclasts in a more sandy matrix.

An analysis of the number of contourite and turbidite beds observed (Fig. F7) suggests that turbidite and contourite beds are distributed throughout the recovered section. The number of silt-dominated and sand-dominated beds per core shows some variation, with more beds per meter observed at $\sim 120$ 140 mbsf (Cores 339-U1388B-14X and 15X). Sandy contourite beds are also somewhat more common in this depth range.

Burrows are common secondary sedimentary structures, although bioturbation is generally sparse to slight. In many cases, burrows have a sandy fill similar to the overlying or underlying bed. One possible subvertical burrow found near a lithologic contact is $>1 \mathrm{~cm}$ wide and $28 \mathrm{~cm}$ long (interval 339-U1388$6 \mathrm{X}-2,7-35 \mathrm{~cm}$ ) and is filled with clean mediumgrained sand that is coarser than either the overlying or underlying unit.

\section{Composition}

The results of smear slide analysis showing sediment composition and grain size are given in Table T2. These observations indicate that detrital carbonate is more common in lithologies with intermediate grain sizes (silty sand, sandy silt, and silty mud) than in the finer (mud with nannofossils) or coarser grained sediments (sand). Biogenic silica is rarely observed. A diverse suite of minerals from a variety of source rocks is present in many samples (Fig. F18).

Several well-preserved gastropods are present in Unit I (Fig. F19). These species can be found living on the Iberian shelf today, but it is not certain if they can live in deeper water. However, the gastropods recovered at this site were found in a variety of lithologies-in a silty sand contourite, a mud, and the surface sand layer (Fig. F19, top, center and bottom, respectively) - suggesting that the shells were found in situ.

\section{Color}

Sediment colors are generally described as light to dark gray near the surface, greenish gray or grayish brown in Cores 339-U1388C-3R through 4R, and varying downhole between greenish gray, dark greenish gray, and very dark greenish gray. The most common color is dark greenish gray. 


\section{Bulk mineralogy}

XRD analysis was conducted on 22 powdered bulk samples, which generally were taken once per core the first time a particular stratigraphic level was sampled. Six samples were analyzed for clay fraction mineralogy, chosen as a subset of the suite of bulk mineralogy samples (Table T3; Figs. F20, F21). The bulk XRD results indicate that the mineral composition varies considerably above $\sim 50 \mathrm{mbsf}$ and is somewhat more uniform through the rest of the cored interval. The samples at $2.6 \mathrm{mbsf}$ in Hole U1388A (Sample 339-U1388A-1H-2, 115-116 cm) and 36.3 mbsf in Hole U1388B (Sample 339-U1388B-5X-CC, $31-32 \mathrm{~cm}$ ) produce high-intensity peaks at characteristic angles for plagioclase, K-feldspar, and illite. Hornblende has peak intensities similar to those from other sites, and a sample at 138.7 mbsf in Hole U1388B has a fairly large intensity for a pyroxene (augite) peak. The sample processed for clay minerals at 2.65 mbsf in Hole U1388A is sandy and contains no clay minerals. Unglycolated samples from other depths show peaks for illite, kaolinite, and chlorite, as well as an elevated baseline between the chlorite and illite peaks. When glycolated, the baseline in this interval decreases and a more intense peak appears at lower angles on the diffractogram, indicating that poorly crystalline clays have expanded to the characteristic d-spacing of $17.8 \AA$, typical of smectite expanded with glycol.

\section{Discussion}

Unit I contains a significant number of sandy beds, with thicknesses up to several meters, as well as many intervals of mud with biogenic carbonate that exceed $15 \mathrm{~m}$ thick. The latter provide relatively good age control (see "Biostratigraphy"). Full understanding of sedimentation at this site is hampered by partial recovery. Based on the recovered material, however, both contourites and turbidites have been identified in relatively similar numbers, and both contourites and turbidites are distributed through the entire length of Unit I. These relatively similar abundances and stratigraphic distributions indicate that both alongslope and downslope processes were important for delivering sediment to Site U1388 throughout the time indicated by the cored record.

Some details in the record at Site U1388 do suggest that the relative importance of alongslope vs. downslope flow changed through time. For example, the number of contourite beds increases in Cores $339-\mathrm{U} 1388 \mathrm{~B}-14 \mathrm{X}$ and $15 \mathrm{X}$, possibly caused by changes in current strength at that time. Also, some intervals containing lighter colored sand laminae may indicate sediment reworking by currents and re- moval of the fine fraction. The presence of two apparent mass transport units (a debrite and a slump) reinforce the importance of downslope transport.

Given the evidence for sustained activity of both alongslope currents and downslope processes, the possibility existed for numerous interactions between downslope and alongslope currents during deposition of Unit I. This range of interactions may help explain the irregular development of sharp contacts at the bases or tops of sandy sequences, as well as the deposition of inversely graded beds. Some normally graded and sharp-based (base-cut-out) beds could be also contourites, as in Site U1389 (see "Lithostratigraphy" for Site U1389 [Expedition 339 Scientists, 2013d]), and further detailed studies are necessary to differentiate them from turbidite beds. Several of the intervals investigated by optical and XRD techniques have relatively high percentages of rock-forming minerals other than quartz, suggesting an immature mineral assemblage and the possibility of relatively direct sediment supply to Site U1388 through downslope processes.

\section{Biostratigraphy}

Sediments recovered at Site U1388 include silty sands and sands (see "Lithostratigraphy"). Marine microfossil and nannofossil abundance was therefore lower than at the previous sites. Several samples are barren or almost barren, especially of foraminifers. Preservation, on the other hand, was often very good to good, with only few samples showing moderate preservation. A rare occurrence of pteropods was observed in Sample 339-U1388B-22X-CC. Ostracods were not studied at Site U1388, and only two samples from Hole U1388B were analyzed for pollen. The total pollen and spores concentrations were similar to those from previous Sites U1386 and U1387, ranging between 15,000 and 34,000 grains $/ \mathrm{cm}^{3}$. The preservation was moderate to poor. Microcharcoal particles and dinocysts were also observed.

The deepest reliable biostratigraphic event is the last occurrence (LO) of Pseudoemiliania lacunosa (0.46 $\mathrm{Ma}$ ), placed at 170 mbsf in Hole U1388B (Table T4). The estimated sedimentation rate between this nannofossil event and the one above is $60 \mathrm{~cm} / \mathrm{k} . \mathrm{y}$. If this sedimentation rate is extrapolated to the base of Hole U1388B, the basal age is $\sim 0.56 \mathrm{Ma}$, which is in good agreement with the absence of the benthic foraminifer "Stilostomella extinction" event occurring between 0.58 and $0.70 \mathrm{Ma}$. The Holocene/Pleistocene boundary could not be defined, but based on the planktonic foraminifer assemblage, Sample 339U1388A-1H-CC likely dates from the Holocene. 


\section{Calcareous nannofossils}

We examined all the core catcher samples from Holes U1388A-U1388C for calcareous nannofossil biostratigraphy. Calcareous nannofossil assemblages are abundant to rare, with the exception of Sample 339-U1388B-9X-CC, which is barren. Preservation is moderate, with the presence of dissolution and overgrowth in some samples. Small placolith species $(<3$ $\mu \mathrm{m})$ dominate most of the assemblages (Table T5).

Two Pleistocene nannofossil datums defined and/or calibrated by Raffi et al. (2006 and references therein) were identified in all holes (Table T4).

The FO of Emiliania huxleyi (0.26 Ma), which marks the base of Zone NN21, was placed between Samples 339-U1388B-6X-CC and 7X-CC (47.47-56.14 mbsf). However, this event should be taken with caution because of dissolution effects and the low proportion of this species. The LO of P. lacunosa (0.46 Ma), considered a globally synchronous event that defines the top of Zone NN19, occurs between Samples 339U1388B-18X-CC and 19X-CC (162.82-178.02 mbsf).

\section{Planktonic foraminifers}

The core catcher samples from Site U1388 contain high amounts of lithic grains (commonly in the fine sand range; Table T6). Therefore, planktonic foraminifer abundance is relatively low (abundant to present). Foraminifer abundance exceeds 30\% only in Sample 339-U1388B-2X-CC. Three samples from Hole U1388B are barren, and four additional samples are almost barren. Preservation is often very good, revealing pristine foraminifer shells. Three samples (339-U1388B-4X-CC, 17X-CC, and 19X-CC) show only moderate preservation. The planktonic foraminifer assemblage is typical for this region, with species linked to temperate to subtropical waters. Similar to the previous sites, the assemblages are dominated by Globigerina bulloides, Neogloboquadrina pachyderma (dextral), and Globorotalia inflata. Orbulina universa, Globorotalia truncatulinoides, and Globigerinella siphonifera contribute regularly to the fauna. Sample 339-U1388A-1H-CC contains Globigerinoides trilobus and Globigerinoides sacculifer and therefore most likely dates from the Holocene.

\section{Benthic foraminifers}

Samples 339-U1388A-1H-CC, 339-U1388B-1H-CC through 24X-CC, and 339-U1388C-2R-CC through 4R-CC were analyzed for benthic foraminiferal assemblages (Table T7). As with Sites U1386 and U1387, the abundance and preservation of benthic foraminifers is related to lithology, and higher abun- dance and well-preserved benthic foraminifers are observed in finer sediments. The abundance of benthic foraminifers fluctuates from rare to highly abundant. Samples 339-U1388B-5X-CC and 9X-CC and 339-U1388B-18X-CC are barren. In most of the samples that revealed foraminifers, benthic assemblages are moderately to well preserved, except for Samples 339-U1388B-4X-CC and 7X-CC.

The benthic foraminiferal fauna is mainly composed of species of Brizalina, Bulimina, Cassidulina, Cibicidoides, Globobulimina, Sphaeroidina, and Uvigerina in varying proportions. In general, an upper bathyal environment is indicated. Transport from the shelf, indicated by Ammonia beccarii, Asterigerinata planorbis, and Elphidium spp., occurs sporadically and is mainly restricted to the upper part of the succession. Two major assemblages can be distinguished that suggest variations in ventilation and/or MOW current strength and that alternate throughout the succession:

Assemblages composed of Brizalina dilatata, Bulimina aculeata, Cassidulina laevigata/teretis, and Sphaeroidina bulloides characterize environments with increased organic matter flux and reduced ventilation (van Morkhoven et al., 1986; Leckie and Olson, 2003; Murray, 2006). Peak abundances of Brizalina spp. (Sample 339-U1388B-12X-CC, 14X-CC, and 20X-CC) indicate maxima in oxygen depletion of bottom water related to enhanced input of organic matter and/or a well-stratified water column.

Assemblages with high abundances of Cibicides/Cibicidoides spp. and Uvigerina spp. (Samples 339U1388B-3X-CC, 7X-CC, 15X-CC, 21X-CC through 24X-CC, and 339-U1388C-2R-CC through 4R-CC) indicate increased ventilation, potentially related to an increase in MOW current strength. Within some of these assemblages, the "epibenthos group," suggested as an indicator for MOW intensity in the area (Schönfeld, 1997, 2002; Schönfeld and Zahn, 2000), shows abundances of $>5 \%$. The exceptionally high abundance of Cibicides lobatulus in Sample 339U1388B-3X-CC might be related to a peak in MOW strength close to the exit of the Strait of Gibraltar.

The Stilostomella extinction event was not recognized at Site U1388, thus suggesting that the deposits are younger than 0.58-0.7 Ma (Hayward, 2002; Kawagata et al., 2005). However, in Sample 339U1388B-2X-CC, several moderately well preserved tests of Pleurostomella alternans, Siphonodosaria ketienziensis, and Siphonodosaria subtertenuata were found, which are absent in all other samples. As the same sample yields very high abundances of reworked 
early Pleistocene nannofossils, we consider the foraminiferal tests reworked too.

\section{Palynology}

Samples 339-U1388B-2X-CC and 14X-CC were analyzed for palynology. The main pollen types found at this site, deciduous and evergreen Quercus, Olea, Ericaceae, Chenopodiaceae, Artemisia, Taraxacum-type, and Poaceae (Table T8), are those already observed at the previous Sites U1386 and U1387 (see "Palynology" in the "Site U1386" chapter [Expedition 339 Scientists, 2013b] and "Palynology" in the "Site U1387" chapter [Expedition 339 Scientists, 2013c]). The first sample is characterized by poorly preserved pollen morphotypes and, as is normal for such samples, an abundance of Taraxacum-type pollen grains. The sample below, Sample 339-U1388B-14X-CC, is composed of an important fraction of well-preserved pollen grains dominated by semidesert elements, mainly Artemisia and Chenopodiaceae, indicating a period of arid and cold conditions in the close continents between 0.26 and $0.46 \mathrm{Ma}$ (Table T4).

\section{Paleomagnetism}

Paleomagnetic investigation of the APC, XCB, and RCB cores collected at Site U1388 included measurement of magnetic susceptibility of whole-core and archive-half split-core sections and the natural remanent magnetization (NRM) of archive-half split-core sections. NRM was measured before and after alternating field (AF) demagnetization with $20 \mathrm{mT}$ peak field for all studied cores of the site. Stepwise AF demagnetization of 10 selected discrete samples was performed at successive peak fields of $0,5,10,15,20$, $25,30,35,40,45,50,55,60,70$, and $80 \mathrm{mT}$ to verify the reliability of the split core measurements and to determine the demagnetization behavior of the recovered sediment. The depth levels where the measured discrete samples were taken are indicated by blue triangles in the first panel of Figure F22. We processed data extracted from the Laboratory Information Management System (LIMS) database by removing all measurements collected from disturbed and void intervals, which are listed in Table T9, and all measurements that were made within $10 \mathrm{~cm}$ of the section ends, which are slightly biased by measurement edge effects. The processed NRM inclination, declination, and intensity data after $20 \mathrm{mT}$ peak field AF demagnetization are listed in Tables T10, T11, and T12.

\section{Natural remanent magnetization and magnetic susceptibility}

The intensity of NRM after $20 \mathrm{mT}$ peak field AF demagnetization is in the range of $\sim 10^{-4}$ to $\sim 10^{-2} \mathrm{~A} / \mathrm{m}$ (Fig. F22, third panel). The sands from lithologic Unit I (Core 339-U1388A-1H; see "Lithostratigraphy") exhibit very low intensities $\left(\sim 10^{-4} \mathrm{~A} / \mathrm{m}\right)$ and are underlain by sediment with moderately high intensity values $\left(\sim 10^{-3}-10^{-2} \mathrm{~A} / \mathrm{m}\right)$.

Despite the XCB-induced coring disturbance and the drill string overprint, a very stable magnetic component was preserved in the sediment. A magnetic overprint with steep, positive inclination, which was probably acquired during drilling, was usually removed by up to $20 \mathrm{mT}$ peak field AF demagnetization (Fig. F23). Although the XCB cores are heavily biscuited and frequently contain as much of the disturbed matrix as the intact material, the quality of the resulting paleomagnetic data is excellent and sufficient to determine the magnetic polarity.

Except for two discrete samples from Hole U1388A that consist of mainly sands from lithologic Unit I (see "Lithostratigraphy") and failed to yield stable NRM, progressive AF demagnetization of eight discrete samples from Hole U1388B revealed stable NRM with positive inclinations (Fig. F23). Several samples exhibit a steep, normal overprint that was generally removed after AF demagnetization at peak field of 15-20 mT, demonstrating that the $20 \mathrm{mT}$ magnetic cleaning level is, in general, sufficient to eliminate the overprint. A few samples also appear to have acquired a significant amount of anhysteretic remanent magnetization at high peak field $(>55 \mathrm{mT}$ ) AF demagnetization steps, especially for one sample from 160.86 mbsf in Hole U1388B (Fig. F23). The acquired anhysteretic remanent magnetization is possibly because of bias caused by ambient magnetic field during AF demagnetization at high peak fields. We calculated component NRM directions of the eight discrete samples from data from $25-50 \mathrm{mT}$ demagnetization steps using principal component analysis (Kirschvink, 1980) and the UPmag software (Xuan and Channell, 2009). Maximum angular deviations associated with the principal component analysis are mostly $<10^{\circ}$, suggesting the component NRM directions are reasonably well defined. Component NRM inclinations of these discrete samples vary between $\sim 50^{\circ}$ and $65^{\circ}$ (Fig. F22, yellow circles on inclination panel) and are generally consistent with the archive-half section measurements. 
Magnetic susceptibility measurements were made on whole cores from all three holes as part of the Whole-Round Multi Sensor Logger (WRMSL) analysis and on archive-half split core sections using the Section Half Multi Sensor Logger (SHMSL) (see "Physical properties"). Magnetic susceptibility is consistent between the two instruments and, in general, parallels the intensity of magnetic remanence. The WRMSL acquired susceptibility was stored in the database in raw meter units. These were multiplied by a factor of $0.68 \times 10^{-5}$ to convert to the dimensionless volume SI unit (Blum, 1997). A factor of (67/ $80) \times 10^{-5}$ was multiplied by the SHMSL acquired susceptibility stored in the database. Magnetic susceptibility varies between $5 \times 10^{-5}$ and $40 \times 10^{-5}$ SI (Fig. F22, fourth panel). Note that in Figure F22, a constant of $25 \times 10^{-5}$ SI was added to the SHMSL measurements (gray lines) to facilitate the comparison with the WRMSL measurements (black lines).

\section{Magnetostratigraphy}

The geomagnetic field at the latitude of Site U1388 $\left(36.27^{\circ} \mathrm{N}\right)$ has an expected inclination of $55.73^{\circ}$, assuming a geocentric axial dipole model, which is sufficiently steep to determine magnetic polarity in cores that lack a horizontal orientation. NRM inclination data (after $20 \mathrm{mT}$ peak field AF demagnetization) from all three holes indicate that only the Brunhes (C1n) normal polarity chron is recorded in these sediments (Fig. F22). This interpretation is supported by the discrete sample measurements. A discrete sample from the base of Hole U1388B (Sample 339-U1388B-24X-7, 44-46 cm) clearly carries a positive inclination and is $<0.781 \mathrm{Ma}$. Whether the Brunhes Chron is complete or incomplete cannot be determined from the magnetostratigraphy. However, preliminary biostratigraphic datums (see "Biostratigraphy") indicate an age between 600 and $900 \mathrm{ka}$ at the base of Hole U1388B.

\section{Physical properties}

The shipboard physical properties program at Site U1388 included high-resolution nondestructive measurements of gamma ray attenuation (GRA) density, magnetic susceptibility (loop sensor), $P$-wave velocity (mostly in $2.5 \mathrm{~cm}$ steps), and NGR on wholeround core sections measured each $20 \mathrm{~cm}$. Thermal conductivity was not obtained at this site because of poor recovery and sediment disturbance. Discrete measurements of $P$-wave velocity were determined on every other working-half section in Hole U1388B between Cores 12X and 20X. Moisture and density (MAD) were measured once in every section as 10 $\mathrm{cm}^{3}$ discrete samples. Color reflectance spectrometry and split-core point-logger magnetic susceptibility were obtained for every section in each hole in $5 \mathrm{~cm}$ steps. Based on physical properties, three intervals were distinguished. The first interval (physical properties Unit I), between 0 and 100 mbsf, is characterized by low core recovery and high-frequency variations of all parameters. A second interval (physical properties Unit II), between 100 and 150 mbsf, is characterized by high core recovery and a marked positive relationship between GRA density and magnetic susceptibility values. A third interval (physical properties Unit III), from $\sim 150$ mbsf to the bottom of the hole, displays low magnetic susceptibility values and indistinct relations between the different parameters.

\section{Whole-Round Multisensor Logger measurements}

After allowing the cores to equilibrate for $3 \mathrm{~h}$, GRA bulk density and magnetic susceptibility were measured in all core sections at $2.5 \mathrm{~cm}$ intervals at Site U1388 using the WRMSL (Fig. F24).

\section{Gamma ray attenuation density}

Variations in GRA density may reflect changes in lithology, consolidation, cementation, and porosity. Measured GRA density ranges between 1.26 and 2.01 $\mathrm{g} / \mathrm{cm}^{3}$ in Hole U1388A, showing a steady increase in the upper intervals that probably reflects the presence of a coarse sand layer. A marked decrease observed in the lower part of the hole can be linked with an increase in fine sand content (Fig. F24).

In Hole U1388B from 0 to 100 mbsf, core recovery was very poor and GRA density ranges between 1.7 and $2.2 \mathrm{~g} / \mathrm{cm}^{3}$. Despite the poor recovery, distinct high-frequency variations can be recognized (e.g., Cores 339-U1388B-9X and 10X). These high-frequency variations are also present in the upper part of Core 339-U1388B-12X, in which recovery is higher. The boundary between this high-frequency to lower frequency variation further downhole is in Core 339-U1388B-12X at $\sim 110$ mbsf. This boundary also can be distinguished by a change in lithology, concomitant with a decrease in the number of sandy turbidite layers (see "Lithostratigraphy").

GRA density below 110 mbsf has almost the same values as those obtained from discrete samples. Density values range between 1.9 and $2.1 \mathrm{~g} / \mathrm{cm}^{3}$ in the interval between 110 and 150 mbsf for MAD and between 1.6 and $2.1 \mathrm{~g} / \mathrm{cm}^{3}$ for GRA. There was high core recovery in this interval, which allows us to identify a strong link between GRA density, magnetic susceptibility, and the presence of silt and sands. Despite the positive correlation between GRA 
density and magnetic susceptibility, the relationship between NGR and the color reflectance parameters $\mathrm{L}^{*}$ and $\mathrm{a}^{*}$ is complex. Comparing GRA density to $\mathrm{L}^{*}$ shows that high GRA density is not clearly associated with distinct changes in sediment lightness. In general, GRA density and NGR show a negative correlation in this interval, a relationship contrasting with that at other sites. This complex pattern can be linked with the abundance of detrital material including mica, zircon, glauconite, opaques, heavy minerals, and feldspars (see "Lithostratigraphy") in both muddy and sandy layers.

In the lower part of Site U1388, GRA density values range between 1.6 and $2.1 \mathrm{~g} / \mathrm{cm}^{3}$. The GRA density variations are difficult to correlate with changes in grain size (e.g., Cores 339-U1388B-19X and 20X). This could be linked with changes in the nature or fabric of the grains, as indicated by grain density variations (Fig. F25). The highest GRA density values in this interval correspond to layers with coarse grain size and low NGR values. Typically, sandy beds are associated with low GRA density, so this unexpected result could be explained by an unusual mineralogical composition.

\section{Magnetic susceptibility}

The most notable aspects of the magnetic susceptibility records at Site U1388 are the cyclical and smooth variations observed between 100 and 150 mbsf and the low values below 150 mbsf (Fig. F24). In the upper $100 \mathrm{~m}$ (physical properties Unit I), where core recovery was poor, susceptibility values range from $10 \times 10^{-5}$ to $30 \times 10^{-5} \mathrm{SI}$. In physical properties Unit II, where core recovery was high, magnetic susceptibility long-term trends show three major cycles that become progressively more intense, with average values between $10 \times 10^{-5}$ and $40 \times 10^{-5}$ SI. Other minor cycles and spikes are superimposed on the major cycles and reach $80 \times 10^{-5} \mathrm{SI}$, the highest magnetic susceptibility value. These cyclic variations are mirrored by GRA density values and are associated with the presence of silty/sandy layers with high magnetic susceptibility.

Magnetic susceptibility values are low $\left(<20 \times 10^{-5}\right.$ SI $)$ from $~ 150$ mbsf to the bottom of the hole (physical properties Unit III). This observation is also supported by low NRM values (see "Paleomagnetism"). Despite these low values, the composition of the sediment appears to be almost the same as in the overlying intervals, suggesting that diagenetic processes are controlling magnetic susceptibility in this interval. A likely factor for the main decrease of magnetic susceptibility is the reduction of fine-grained magnetite to iron sulfides below the sulfate reduction zone. However, the present sulfate-methane transition
(SMT) zone, occurring around 40 mbsf and recognized in Hole U1388B (see "Geochemistry"), shows no correlation between low magnetic susceptibility and this boundary.

\section{$\boldsymbol{P}$-wave velocity}

No reasonable $P$-wave velocity measurements were retrieved using the WRMSL. An attempt was made to determine $P$-wave velocities on split cores in each section of Hole U1388B (Fig. F24). Because of low core recovery and poor sediment to liner coupling, reasonable results from split cores were recovered only between $\sim 100$ and $\sim 180 \mathrm{mbsf}$ and values range between 1550 and $1730 \mathrm{~m} / \mathrm{s}$. $P$-wave velocities determined by the split-core logger do not show a clear correlation with any other physical property or lithology. Caution must be taken in interpreting the manually picked data, in which greater subjectivity and poorer signal quality lead to higher scatter in the data. The method of manually picking data tends to overestimate velocities.

\section{Natural gamma radiation}

NGR was measured on all core sections at $20 \mathrm{~cm}$ spacing and run on an integration time of $7 \mathrm{~min}$ per section. Measured values range from 20 to $45 \mathrm{cps}$, with a single peak reaching 88 cps in Core 339U1388B-12X, which was not plotted because it appears to be an artifact. No distinctive explanatory feature can be found in the sediment (Fig. F26).

In Hole U1388A there is an interval of coarse sediment, in which NGR has low values around $19 \mathrm{cps}$. In the high-recovery interval from $\sim 100$ to $\sim 150$ mbsf in Hole U1388B, we can observe three cycles with progressively increasing amplitudes in NGR and a marked increase at the base of Core 339-U1388A16X. Along this interval, NGR shows mainly negative correlations with magnetic susceptibility and GRA density. However, NGR values do not always reflect observed changes in grain size. This can be related to the described homogeneous mineral composition (see "Lithostratigraphy").

Below 150 mbsf core recovery is poorer, but major variations in NGR values can be distinguished in Cores 339-U1388B-18X, 20X, and 22X. In these cases, NGR values increase and decrease by 10 cps over $\sim 2 \mathrm{~m}$. Lows in NGR counts appear to be related to the presence of coarse sand deposits, probably with a lower content of K-feldspars or any other mineral enriched in potassium and thorium contents. This marked decrease in NGR is coincident with an increase in GRA density and relatively high values in grain density. No obvious correlation can be found in this interval between NGR and color reflectance parameters. 


\section{Moisture and density}

Measurements of bulk density, porosity, and grain density were undertaken on 2 samples from Hole U1388A, 41 samples from Hole U1388B, and 4 samples from Hole U1388C. One MAD sample was taken every other section. The samples were taken at the same depths, approximately $60 \mathrm{~cm}$ from the top of the section, when available. Care was also taken to avoid locations with obvious drilling disturbance. These samples were measured for wet mass and dry density to calculate bulk density and grain density.

The MAD bulk densities from discrete samples are plotted in Figure F24 and show a range of $1.9-3.2 \mathrm{~g} / \mathrm{cm}^{3}$. In the upper 110 mbsf, GRA and MAD bulk densities show certain offsets, where discrete sample densities are occasionally higher than those measured with the WRMSL. In the interval of high recovery between 110 and $150 \mathrm{mbsf}$, densities obtained by both techniques are in agreement. For the lowermost interval, below 150 mbsf, WRMSL values are lower because of poor core recovery and incompletely filled core liners, which affect the accuracy of the WRMSL measurements.

The patterns of porosity and moisture content in the interval between 110 and 150 mbsf stand out with respect to those of the other physical parameters, as they have only two amplitude cycles instead of three (Fig. F25). These two cycles appear to be related to long-term compositional changes interrupted by a coarser layer in Core 339-U1388B-15X. In general, samples taken from predominantly silt/sandy sections show lower values in porosity and moisture content. In addition, wet bulk densities appear to be higher in coarse-grained levels. This observation is not sufficiently resolved. Notably, only the dry volume of the sample was determined, not the wet bulk volume. Hence, the difference between the two density estimates might be related to the precipitation of salt crystals in the pore space during sample drying at $105^{\circ} \mathrm{C}$, which would affect the determination of dry volumes by pycnometer and all further calculations.

Porosity ranges from $38 \%$ to $50 \%$, decreasing with depth in the upper 100 mbsf (Fig. F25). Bulk densities do not exhibit clear increasing values with depth for Hole U1388B (Fig. F24). The lack of compactionrelated depth trends could be a result of poor core recovery and the relatively shallow depths reached in this site. NGR values indicate compositional variations for certain intervals, although grain density values are relatively constant in the range from $\sim 2.6$ to $\sim 2.8 \mathrm{~g} / \mathrm{cm}^{3}$ without clear trends (Figs. F25, F26). A density peak of $3.2 \mathrm{~g} / \mathrm{cm}^{3}$ is found in Core 339U1388B-24X. Grain densities are on average slightly higher than quartz density $\left(2.65 \mathrm{~g} / \mathrm{cm}^{3}\right)$ and probably reflect the varying degree of heavy minerals, opaques, and zircon in the sediment.

\section{Summary of main results}

The most remarkable observation at Site U1388 with respect to the previous sites is the negative correlation between GRA density and NGR and the inconsistent correlation between GRA density, magnetic susceptibility, and NGR with color reflectance parameters. When we compare physical properties with lithology, we observe that high GRA densities and magnetic susceptibility are associated with layers of coarse sediment. Nevertheless, NGR is not consistently sensitive to grain size variations (e.g., coarse grain layers), which are in some cases coincident with low NGR values but in other cases not. This relationship between physical properties was not observed at the previous sites and could be related to a homogeneous mineral composition in both fine and coarse layers. In any case, the described changes require more detailed analyses in order to be sufficiently explained.

\section{Geochemistry Volatile hydrocarbons}

Headspace gas analysis was performed as a part of the standard protocol required for shipboard safety and pollution prevention monitoring. In total, 20 headspace samples were analyzed, including 1 from Hole U1388A, 18 from Hole U1388B, and 1 from Hole U1388C (Fig. F27; Table T13), spanning the entire depth range of the site. Methane $\left(\mathrm{C}_{1}\right)$, ethane $\left(C_{2}\right)$, and ethene $\left(C_{2=}\right)$ were the only hydrocarbons detected. Methane ranged from 10.38 ppmv near the surface to a maximum of $65,682 \mathrm{ppmv}$ at $160.1 \mathrm{mbsf}$ (Section 339-U1388B-18X-2). Ethane was detected at and below 83.6 mbsf and remained less than 2.75 ppmv. Ethene was detected at and below $147 \mathrm{mbsf}$ and did not exceed $0.82 \mathrm{ppmv}$.

\section{Sedimentary geochemistry}

Sediment samples were collected for analysis of solid-phase geochemistry (inorganic and organic carbon) at a resolution of approximately one sample per core in Holes U1388A-U1388C (Table T14), spanning the maximum penetration at this site. $\mathrm{CaCO}_{3}$ varies from 18.0 to $29.9 \mathrm{wt} \%$ (Fig. F8). Organic carbon is generally low and varies between 0.08 and $0.92 \mathrm{wt} \%$ (Fig. F28A).

Nitrogen was measured downhole to $224.74 \mathrm{mbsf}$, with values ranging from 0.02 to 0.11 wt $\%$ (Fig. 
F28B). The $\mathrm{C} / \mathrm{N}$ ratio, used to distinguish the origin of organic matter (marine versus terrestrial) in sediment (Emerson and Hedges, 1988; Meyers, 1997), indicates that the organic carbon is mainly of marine origin with little terrestrial input (Fig. F28C). The highest $\mathrm{C} / \mathrm{N}$ value of 16 is at 36.34 mbsf, corresponding to a portion of the core with fine-sand composition. The surrounding sediment is mainly clay and silt. A slight positive relationship appears to exist between organic matter content and $\mathrm{C} / \mathrm{N}$ ratios, but it is weaker than at Sites U1385-U1387.

\section{Interstitial water chemistry}

\section{Major cations and anions}

Elemental analyses were made on 14 samples from whole-round samples taken at Site U1388 to a total depth of 211 mbsf, including 1 sample from Hole U1388A and 13 from Hole U1388B.

Sulfate concentrations are near seawater values at the top of the section and decrease to zero by $\sim 50$ mbsf (Fig. F29A; Table T15). Alkalinity generally increases downhole with the exception of a low interval between 125 and 150 mbsf (Fig. F29B). Ammonium gradually increases from near zero at the top of the hole to a maximum of $8000 \mu \mathrm{M}$ at 200 mbsf (Fig. F29C). Methane begins to increase at 50 mbsf, marking the SMT (Fig. F29D).

Calcium, magnesium, and potassium profiles show similar patterns, with a sharp decrease between the top of the hole and 50 mbsf (Fig. F30). Potassium continues to gradually decrease downhole, whereas calcium and magnesium increase. Chloride and sodium increase downhole from seawater values at the top of the section to a maximum of 800 and $690 \mathrm{mM}$ at 211 mbsf, respectively (Fig. F31). The $\mathrm{Na} / \mathrm{Cl}$ ratio remains near the seawater value $(0.86)$ throughout the section.

\section{Minor elements}

Strontium remains near seawater value in the upper $75 \mathrm{mbsf}$ and increases thereafter, reaching its greatest values at the base of the hole (Fig. F32). Barium was below detection in the uppermost sample and increases downhole to a maximum of $57 \mu \mathrm{M}$ between 107 and 128 mbsf. Thereafter, barium decreases downhole to $150 \mathrm{mbsf}$ and averages $\sim 25 \mu \mathrm{M}$ below. Lithium decreases between the surface and $50 \mathrm{mbsf}$ and then increases downhole, exhibiting a pattern similar to that of strontium. Boron is high in the upper 50 mbsf and undergoes a series of stepped decreases downhole at 70, 100, and 150 mbsf. Silicon concentration is $110 \mu \mathrm{M}$ at the surface and generally increases downhole, with a distinct maximum of 647 $\mu \mathrm{M}$ between 160 and 177 mbsf.
Figure F33 shows the relationship of various elemental concentrations versus chloride. Sodium, calcium, magnesium, and strontium show strong positive relationships with chloride, whereas potassium, boron, and barium display a negative correlation with chloride.

\section{Stable isotopes}

Oxygen and hydrogen isotopes were measured on 14 samples from whole-round samples at Site U1388. At the top of the hole, $\delta^{18} \mathrm{O}$ and $\delta \mathrm{D}$ are at bottom water values of $0.8 \%$ and $6.5 \%$, respectively, and increase to $1.3 \%$ and $9.2 \%$ by 50 mbsf, respectively (Fig. F34; Table T16). $\delta \mathrm{D}$ gradually decreases below 50 mbsf toward the base of the hole, whereas average $\delta^{18} \mathrm{O}$ values remain between $1.3 \%$ and $1.4 \%$. $\delta^{18} \mathrm{O}$ and $\delta \mathrm{D}$ are generally positively correlated (Fig. F35).

\section{Discussion}

The interstitial water profiles at Site U1388 reflect a combination of processes, including microbial degradation of organic matter, dissolution, precipitation of authigenic minerals, and the likely influence of a brine. Sulfate reduction is complete in the uppermost 50 mbsf. The increase in alkalinity and decreases in calcium and magnesium reflect authigenic precipitation of calcite and dolomite. This interpretation is supported by a peak in dolomite observed in XRD data at 36.34 mbsf (see "Lithostratigraphy"). The linear downhole increase and high values of sodium and chloride at depth suggest a source for these elements in the deeper sediment. Some mud volcanoes in the Gulf of Cádiz have high salinities derived from dissolution of halite and late-stage evaporites (Hensen et al., 2007; Scholz et al., 2009). Nevertheless, no strong deviation from the seawater value for $\mathrm{Na} / \mathrm{Cl}(0.86)$ at Site $\mathrm{U} 1388$ is apparent, as would be expected from the dissolution of halite $(\mathrm{Na} / \mathrm{Cl}=1)$. Vengosh et al. (1994) suggests that the high salinity values of interstitial waters in Mediterranean Deep Sea Drilling Project sites with $\mathrm{Na} / \mathrm{Cl}$ ratios typical of seawater are the remnants of Miocene hypersaline lakes, and perhaps these brines also are present in the eastern Gulf of Cádiz.

\section{Stratigraphic correlation}

Three holes were drilled at Site U1388. The construction of a composite section was not warranted because of incomplete or lack of recovery. The upper 4 mbsf was cored in both Holes U1388A and U1388B, but there was no recovery in Core 339-U1388B-1H. The interval from 205 to 226 mbsf was cored in both Holes U1388B and U1388C. Recovery was again incomplete over this interval, and the core is partly 
disturbed. Correlation may be possible between Cores 339-U1388B-24X and 339-U1388C-3R, but correlation would be based on one susceptibility peak that is $\sim 0.50 \mathrm{~m}$ higher in Core 339-U1388B-24X than in 339-U1388C-3R.

\section{References}

Akhmetzhanov, A., 2003. Modern analogues of deep-water hydrocarbon reservoirs [Ph.D. thesis]. Moscow State Univ., Russia.

Akhmetzhanov, A., Kenyon, N.H., Habgood, E., Van Der Mollen, A.S., Neilsen, T., Ivanov M., and Shashkin, P., 2007. North Atlantic contourite sand channels. In Viana, A.R., and Rebesco, M. (Eds.), Economic and Palaeoceanographic Significance of Contourite Deposits. Geol. Soc. Spec. Publ., 276(1):25-47. doi:10.1144/

GSL.SP.2007.276.01.02

Akhmetzhanov, A.M., Kenyon, N.H., Habgood, E.L., Gardner, J., Ivanov, M.K., and Shashkin, P., 2002. Sand lobes in the Gulf of Cádiz: towards better understanding of clastic reservoir high-resolution architecture. In Cunha, M., Pinheiro, L., and Suzyumov, A. (Eds.), Geosphere/Biosphere/Hydrosphere Coupling Processes, Fluid Escape Structures and Tectonics at Continental Margins and Ocean Ridges. IOC Workshop Rep., 183:23. (Abstract) http:// www.jodc.go.jp/info/ioc_doc/Workshop/ 127690e.pdf

Blum, P., 1997. Physical properties handbook: a guide to the shipboard measurement of physical properties of deep-sea cores. ODP Tech. Note, 26. doi:10.2973/ odp.tn.26.1997

Brackenridge, R., Stow, D.A.V., and Hernández-Molina, F.J., 2011. Contourite sands: nature, distribution and controls [28th International Association of Sedimentologists (IAS) Meeting of Sedimentology, Zaragoza, Spain, 5-8 July 2011].

Buitrago, J., García, C., Cajebread-Brow, J., Jiménez, A., and Martínez del Olmo, W., 2001. Contouritas: Un Excelente Almacén Casi Desconocido (Golfo de Cádiz, SO de España) [Congreso Técnico Exploración y Producción REPSOL-YPF, Madrid, Spain, 24-27 September 2001].

Emerson, S., and Hedges, J.I., 1988. Processes controlling the organic carbon content of open ocean sediments. Paleoceanography, 3(5):621-634. doi:10.1029/ PA003i005p00621

Expedition 339 Scientists, 2013a. Expedition 339 summary. In Stow, D.A.V., Hernández-Molina, F.J., Alvarez Zarikian, C.A., and the Expedition 339 Scientists, Proc. IODP, 339: Tokyo (Integrated Ocean Drilling Program Management International, Inc.). doi:10.2204/ iodp.proc.339.101.2013

Expedition 339 Scientists, 2013b. Methods. In Stow, D.A.V., Hernández-Molina, F.J., Alvarez Zarikian, C.A., and the Expedition 339 Scientists, Proc. IODP, 339: Tokyo (Integrated Ocean Drilling Program Management International, Inc.). doi:10.2204/iodp.proc.339.102.2013
Expedition 339 Scientists, 2013c. Site U1386. In Stow, D.A.V., Hernández-Molina, F.J., Alvarez Zarikian, C.A., and the Expedition 339 Scientists, Proc. IODP, 339: Tokyo (Integrated Ocean Drilling Program Management International, Inc.). doi:10.2204/

iodp.proc.339.104.2013

Expedition 339 Scientists, 2013d. Site U1387. In Stow, D.A.V., Hernández-Molina, F.J., Alvarez Zarikian, C.A., and the Expedition 339 Scientists, Proc. IODP, 339: Tokyo (Integrated Ocean Drilling Program Management International, Inc.). doi:10.2204/ iodp.proc.339.105.2013

Expedition 339 Scientists, 2013e. Site U1389. In Stow, D.A.V., Hernández-Molina, F.J., Alvarez Zarikian, C.A., and the Expedition 339 Scientists, Proc. IODP, 339: Tokyo (Integrated Ocean Drilling Program Management International, Inc.). doi:10.2204/ iodp.proc.339.107.2013

García, M., Hernández-Molina, F.J., Llave, E., Stow, D.A.V., León, R., Fernández-Puga, M.C., Díaz del Río, V., and Somoza, L., 2009. Contourite erosive features caused by the Mediterranean Outflow Water in the Gulf of Cádiz: Quaternary tectonic and oceanographic implications. Mar. Geol., 257(1-4):24-40 doi:10.1016/j.margeo.2008.10.009

Habgood, E.L., 2002. Alongslope and downslope sediment transport processes in the Gulf of Cádiz [Ph.D. thesis]. Univ. Southampton, United Kingdom.

Habgood, E.L., Kenyon, N.H., Masson, D.G., Akhmetzhanov, A., Weaver, P.P.E., Gardner, J., and Mulder, T., 2003. Deep-water sediment wave fields, bottom current sand channels, and gravity flow channel-lobe systems: Gulf of Cádiz, NE Atlantic. Sedimentology, 50(3):483-510. doi:10.1046/j.1365-3091.2003.00561.x

Hanquiez, V., Mulder, T., Lecroart, P., Gonthier, E., Marchès, E., and Voisset, M., 2007. High resolution seafloor images in the Gulf of Cádiz, Iberian margin. Mar. Geol., 246(1):42-59. doi:10.1016/j.margeo.2007.08.002

Hayward, B.W., 2002. Late Pliocene to middle Pleistocene extinctions of deep-sea benthic foraminifera ("Stilostomella extinction") in the southwest Pacific. J. Foraminiferal Res., 32(3):274-307. doi:10.2113/32.3.274

Hensen, C., Nuzzo, M., Hornibrook, E., Pinheiro, L.M., Bock, B., Magalhães, V.H., and Brückmann, W., 2007. Sources of mud volcano fluids in the Gulf of Cádizindications for hydrothermal imprint. Geochim. Cosmochim. Acta, 71(5):1232-1248. doi:10.1016/ j.gca.2006.11.022

Hernández-Molina, F.J., Llave, E., Somoza, L., FernándezPuga, M.C., Maestro, A., León, R., Medialdea, T., Barnolas, A., García, M., Díaz del Río, V., Fernández-Salas, L.M., Vázquez, J.T., Lobo, F., Alveirinho Dias, J.M., Rodero, J., and Gardner, J., 2003. Looking for clues to paleoceanographic imprints: a diagnosis of the Gulf of Cádiz contourite depositional systems. Geology, 31(1):19-22. doi:10.1130/00917613(2003)031<0019:LFCTPI>2.0.CO;2

Hernández-Molina, F.J., Llave, E., Stow, D.A.V., García, M., Somoza, L., Vázquez, J.T., Lobo, F.J., Maestro, A., Díaz 
del Río, V., León, R., Medialdea, T., and Gardner, J., 2006. The contourite depositional system of the Gulf of Cádiz: a sedimentary model related to the bottom current activity of the Mediterranean Outflow Water and its interaction with the continental margin. Deep-Sea Res., Part II, 53(11-13):1420-1463. doi:10.1016/ j.dsr2.2006.04.016

Hernández-Molina, F.J., Serra, N., Stow, D.A.V., Llave, E., Ercilla, G., and Van Rooij, D., 2011. Along-slope oceanographic processes and sedimentary products around the Iberian margin. Geo-Mar. Lett., 31(5-6):315-341. doi:10.1007/s00367-011-0242-2

Kawagata, S., Hayward, B.W., Grenfell, H.R., and Sabaa, A., 2005. Mid-Pleistocene extinction of deep-sea foraminifera in the North Atlantic Gateway (ODP Sites 980 and 982). Palaeogeogr., Palaeoclimatol., Palaeoecol., 221(34):267-291. doi:10.1016/j.palaeo.2005.03.001

Kenyon, N.H., and Belderson, R.H., 1973. Bed forms of the Mediterranean undercurrent observed with side-scan sonar. Sediment. Geol., 9(2):77-99. doi:10.1016/00370738(73)90027-4

Kirschvink, J.L., 1980. The least-squares line and plane and the analysis of palaeomagnetic data. Geophys. J. R. Astron. Soc., 62(3):699-718. doi:10.1111/j.1365246X.1980.tb02601.x

Leckie, R.M., and Olson, H.C., 2003. Foraminifera as proxies of sea-level change on siliciclastic margins. In Olson, H.C., and Leckie, R.M. (Eds.), Micropaleontologic Proxies of Sea-Level Change and Stratigraphic Discontinuities. Spec. Publ._SEPM (Soc. Sediment. Geol.), 75:5-19.

Legg, S., Briegleb, B., Chang, Y., Chassignet, E.P., Danabasoglu, G., Ezer, T., Gordon, A.L., Griffies, S., Hallberg, R., Jackson, L., Large, W., Özgökmen, T.M., Peters, H., Price, J., Riemenschneider, U., Wu, W., Xu, X., and Yang, J., 2009. Improving oceanic overflow representation in climate models: the gravity current entrainment climate process team. Bull. Am. Meteorol. Soc., 90:(5):657-670. doi:10.1175/2008BAMS2667.1

Llave, E., Hernández-Molina, F.J., Somoza, L., Stow, D.A.V., and Díaz Del Río, V., 2007. Quaternary evolution of the contourite depositional system in the Gulf of Cádiz. Geol. Soc. Spec. Publ., 276:49-79. doi:10.1144/ GSL.SP.2007.276.01.03

Llave, E., Hernández-Molina, F.J., Stow, D., Somoza, L., and Díaz del Río, V., 2005. The contourite depositional system in the Gulf of Cádiz: an example of drifts with reservoir potential characteristics. In Martínez del Olmo, W. (Ed.), Asociación de Geólogos y Geofísicos Españoles del Petróleo (XXV aniversario): Madrid (AGGEP and REPSOL-YPF), 53-73. http://www.aggep.org/AGGEP/ Documentos/Intro\%20XXV\%20Aniversario.pdf

Llave, E., Matias, H., Hernández-Molina, F.J., Ercilla, G., Stow, D.A.V., and Medialdea, T., 2011. Pliocene-Quaternary contourites along the northern Gulf of Cadiz margin: sedimentary stacking pattern and regional distribution. Geo-Mar. Lett., 31(5-6):377-390. doi:10.1007/s00367-011-0241-3

Madelain, F., 1970. Influence de la topographie du fond sur l’écoulement méditerranéen entre le Détroit de Gibraltar et le Cap Saint-Vincent. Cah. Océanogr., 22:43-61.
Meyers, P.A., 1997. Organic geochemical proxies of paleoceanographic, paleolimnologic, and paleoclimatic processes. Org. Geochem., 27(5-6):213-250. doi:10.1016/ S0146-6380(97)00049-1

Murray, J.W., 2006. Ecology and Applications of Benthic Foraminifera: Cambridge (Cambridge Univ. Press).

Nelson, C.H., Baraza, J., and Maldonado, A., 1993. Mediterranean undercurrent sandy contourites, Gulf of Cádiz, Spain. Sediment. Geol., 82(1-4):103-131. doi:10.1016/0037-0738(93)90116-M

Raffi, I., Backman, J., Fornaciari, E., Pälike, H., Rio, D., Lourens, L., and Hilgen, F., 2006. A review of calcareous nannofossil astrobiochronology encompassing the past 25 million years. Quat. Sci. Rev., 25(23-24):3113-3137. doi:10.1016/j.quascirev.2006.07.007

Scholz, F., Hensen, C., Reitz, A., Romer, R.L., Liebetrau, V., Meixner, A., Weise, S.M., and Haeckel, M., 2009. Isotopic evidence $\left.{ }^{87} \mathrm{Sr} /{ }^{86} \mathrm{Sr}, \delta^{7} \mathrm{Li}\right)$ for alteration of the oceanic crust at deep-rooted mud volcanoes in the Gulf of Cádiz, NE Atlantic Ocean. Geochim. Cosmochim. Acta, 73(18):5444-5459. doi:10.1016/j.gca.2009.06.004

Schönfeld, J., 1997. The impact of the Mediterranean Outflow Water (MOW) on benthic foraminiferal assemblages and surface sediments at the southern Portuguese continental margin. Mar. Micropaleontol., 29(3-4):211236. doi:10.1016/S0377-8398(96)00050-3

Schönfeld, J., 2002. Recent benthic foraminiferal assemblages in deep high-energy environments from the Gulf of Cádiz (Spain). Mar. Micropaleontol., 44(3-4):141-162. doi:10.1016/S0377-8398(01)00039-1

Schönfeld, J., and Zahn, R., 2000. Late glacial to Holocene history of the Mediterranean Outflow. Evidence from benthic foraminiferal assemblages and stable isotopes at the Portuguese margin. Palaeogeogr., Palaeoclimatol., Palaeoecol., 159(1-2):85-111. doi:10.1016/S00310182(00)00035-3

Serra, N., 2004. Observations and numerical modelling of the Mediterranean Outflow [Ph.D. thesis]. Univ. Lisbon, Spain.

Serra, N., Ambar, I., and Boutov, D., 2010. Surface expression of Mediterranean water dipoles and their contribution to the shelf/slope-open ocean exchange. Ocean Sci., 6(1):191-209. doi:10.5194/os-6-191-2010

Stow, D., Brackenridge, R., and Hernandez-Molina, F.J., 2011a. Contourite sheet sands: new deepwater exploration target [presented at the AAPG 2011 Annual Convention and Exhibition, Houston, Texas, 10-13 April, 2011].

Stow, D., Hernández-Molina, FJ., Hodell, D., and Alvarez Zarikian, C.A., 2011b. Mediterranean outflow: environmental significance of the Mediterranean Outflow Water and its global implications. IODP Sci. Prosp., 339. doi:10.2204/iodp.sp.339.2011

Stow, D.A.V., and Faugères, J.-C., 2008. Contourite facies and the facies model. Dev. Sedimentol., 60:223-256. doi:10.1016/S0070-4571(08)10013-9

van Morkhoven, F.P.C.M., Berggren, W.A., and Edwards, A.S., 1986. Cenozoic Cosmopolitan Deep-Water Benthic Foraminifera. Bull. Cent. Rech. Explor.-Prod. Elf-Aquitaine, 11 . 
Vengosh, A., Starinsky, A., and Anati, D.A., 1994. The origin of Mediterranean interstitial waters-relics of ancient Miocene brines: a re-evaluation. Earth Planet Sci. Lett., 121(3-4):613-627. doi:10.1016/ 0012-821X(94)90095-7

Viana, A.R., 2008. Economic relevance of contourites. Dev. Sedimentol., 60:491-510. doi:10.1016/S00704571(08)10023-1

Viana, A.R., Almeida, W., Jr., Nunes, M.C.V., and Bulhões, E.M., 2007. The economic importance of contourites.
Geol. Soc. Spec. Publ., 276(1):1-23. doi:10.1144/ GSL.SP.2007.276.01.01

Xuan, C., and Channell, J.E.T., 2009. UPmag: MATLAB software for viewing and processing $U$ channel or other pass-through paleomagnetic data. Geochem., Geophys., Geosyst., 10(10):Q10Y07. doi:10.1029/2009GC002584

Publication: 17 June 2013

MS 339-106 
Figure F1. 3-D sketch showing the location of Site U1388 $\left(36^{\circ} 16.142^{\prime} \mathrm{N}, 6^{\circ} 47.648^{\prime} \mathrm{W}\right)$ over the contourite terrace in the proximal sector of the contourite depositional system close to the Strait of Gibraltar (made by H. Pereira, Escola Secundária de Loulé, Portugal, using Mirone and iView4D software).

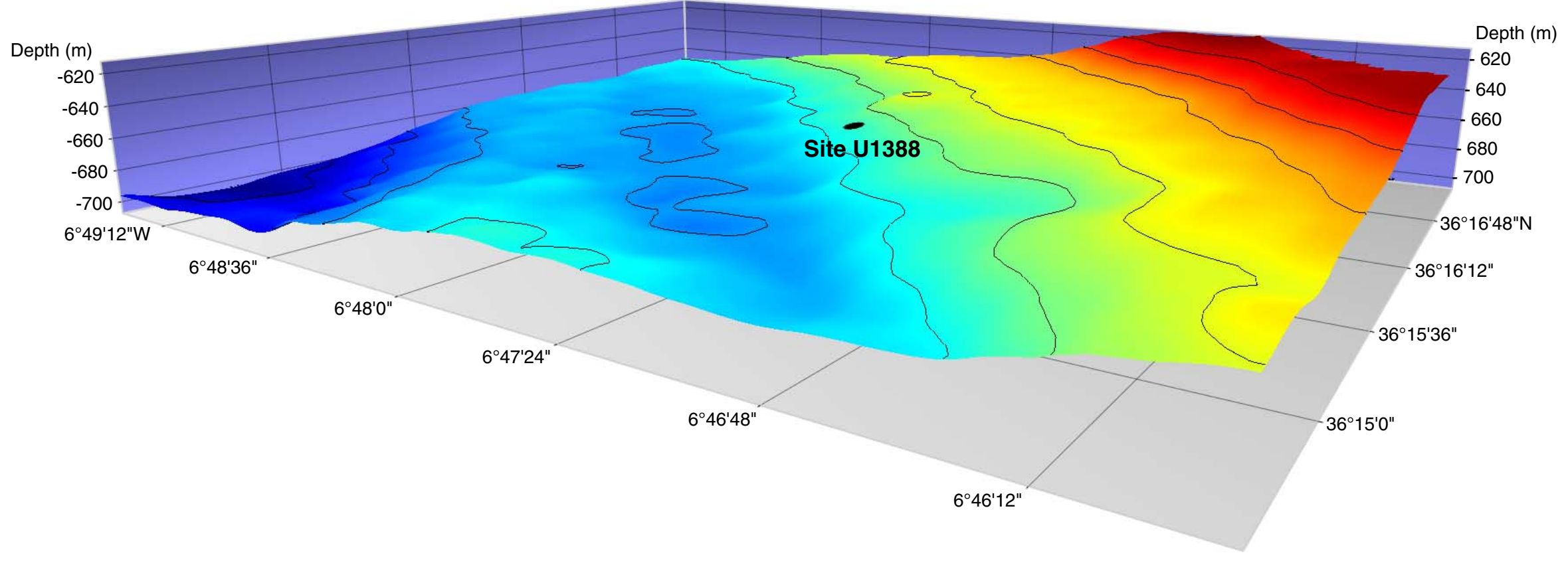


Figure F2. Original Seamap side-scan data including proximal scour and sand ribbons (Sector 1) over the contourite terrace and overflow sedimentary lobe (Sector 2). Red circle indicates location of Site U1388. Furrows legend from Kenyon and Belderson (1973) and Habgood et al. (2003). From Hernández-Molina et al. (2006). Data courtesy of Joan Gardner from Naval Research Laboratory, USA.

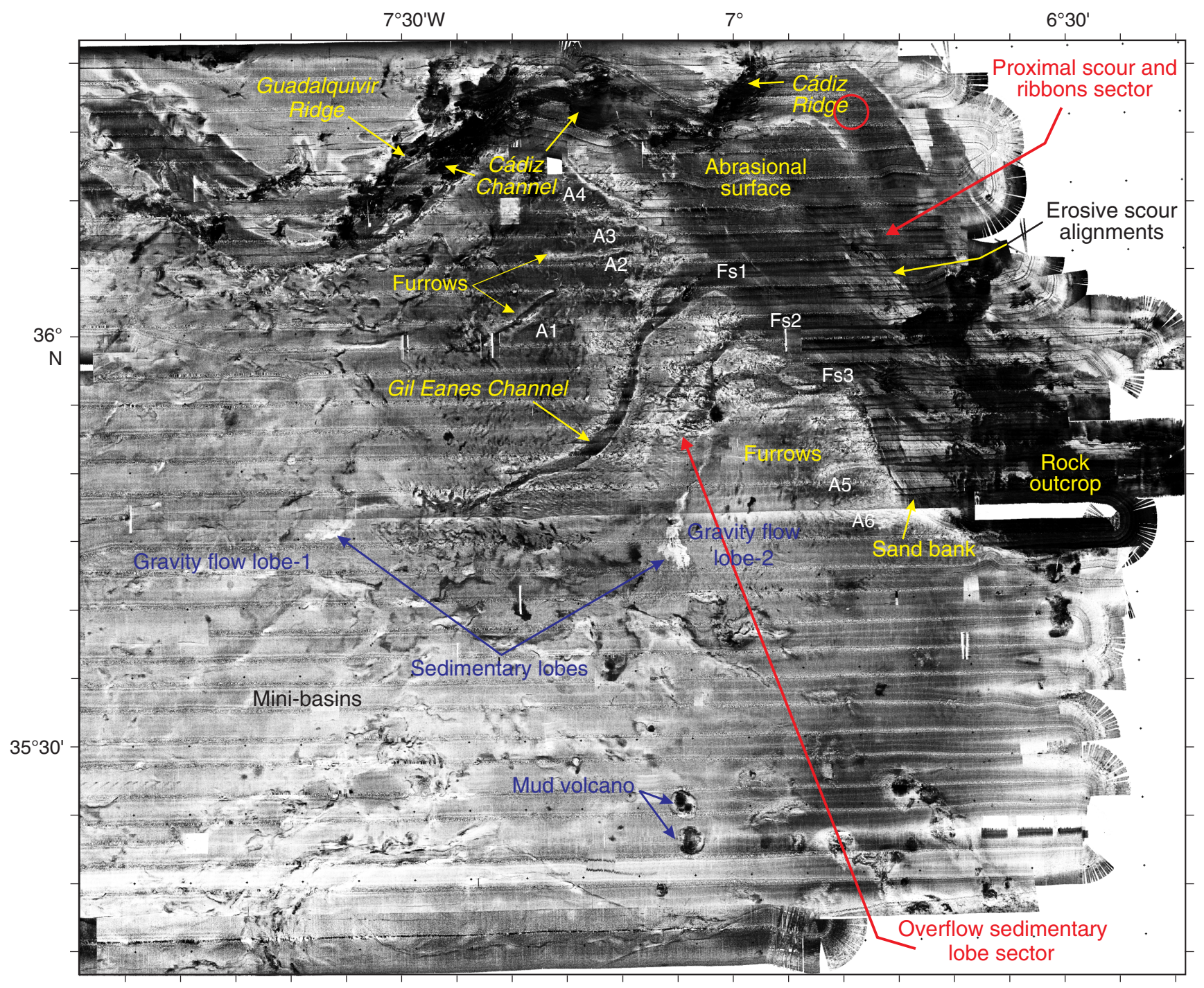


Figure F3. Bathymetric sketch with the location of Site U1388 on an extensive sandy sheeted drift of the proximal Sector 1 of the contourite depositional system close to the Gibraltar Gateway (base map made by Dr. R. León, Geological Survey, IGME, Spain).

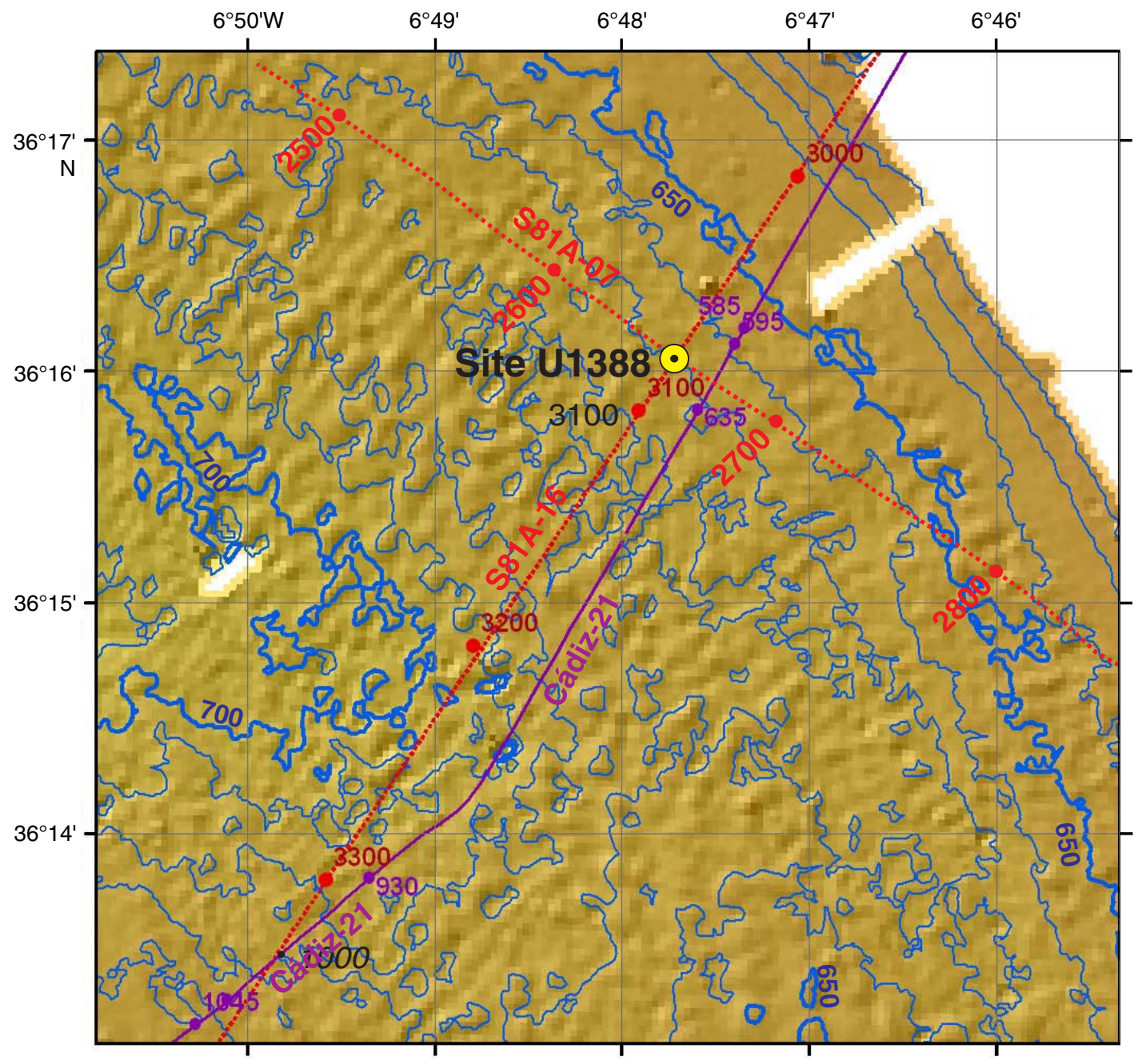

Multichannel Air gun

-0=-=- S81 Contouriber 
Figure F4. Seismic profiles from the proximal scour and sand ribbons Sector 1. From Hernández-Molina et al. (2006) and Llave et al. (2007). A. Sketch sector and seismic lines. B. Abrasional surface with high backscatter intensity. C. Several erosive scour alignments with a northeastsouthwest orientation, smooth V- shaped expression, and truncated reflectors. D. Longitudinal bedforms (southeast to northwest) caused by MOW. Red circle indicates location of Site U1388.
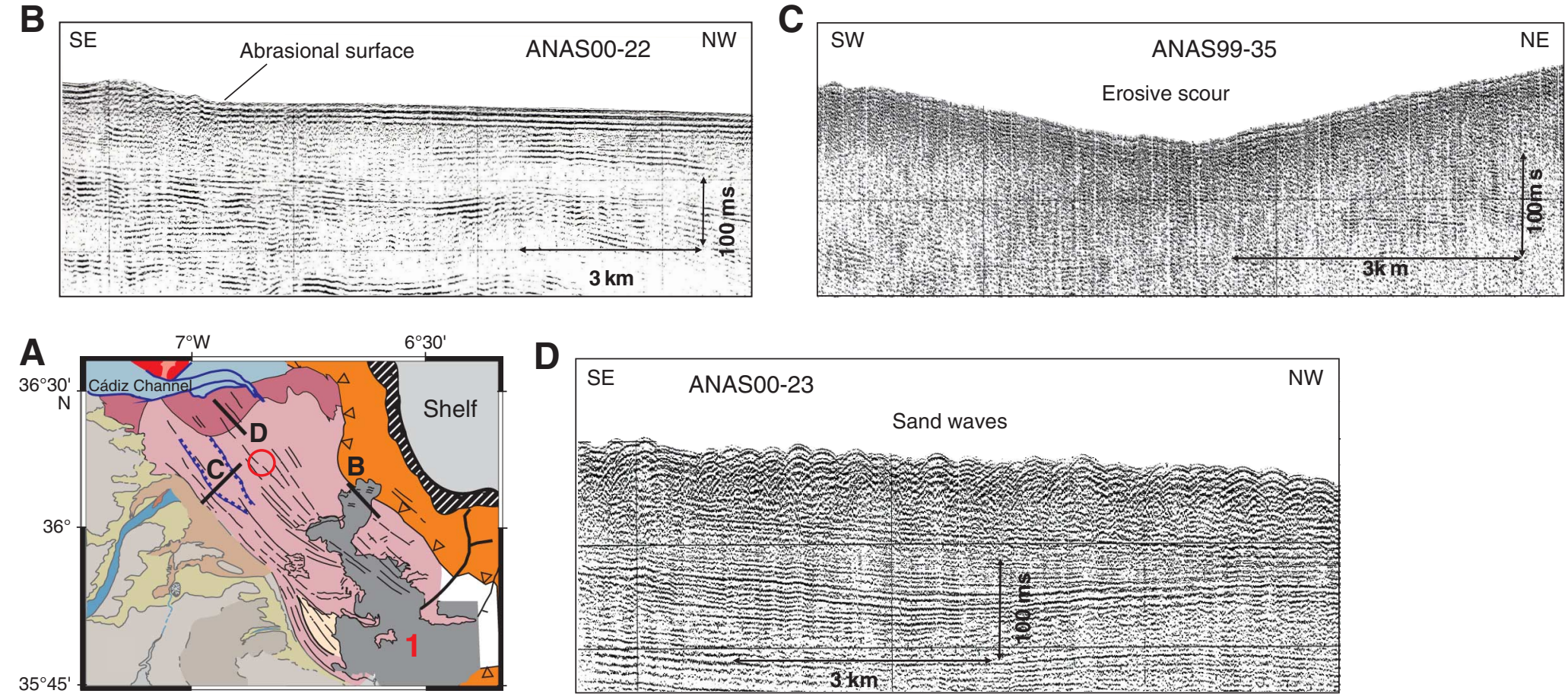
Figure F5. Graphic overview of the oceanographic patterns in the Gulf of Cádiz (from García et al., 2009) showing the circulation pattern of Mediterranean Outflow Water (MOW) cores and branches. Red circle indicates location of Site U1388.

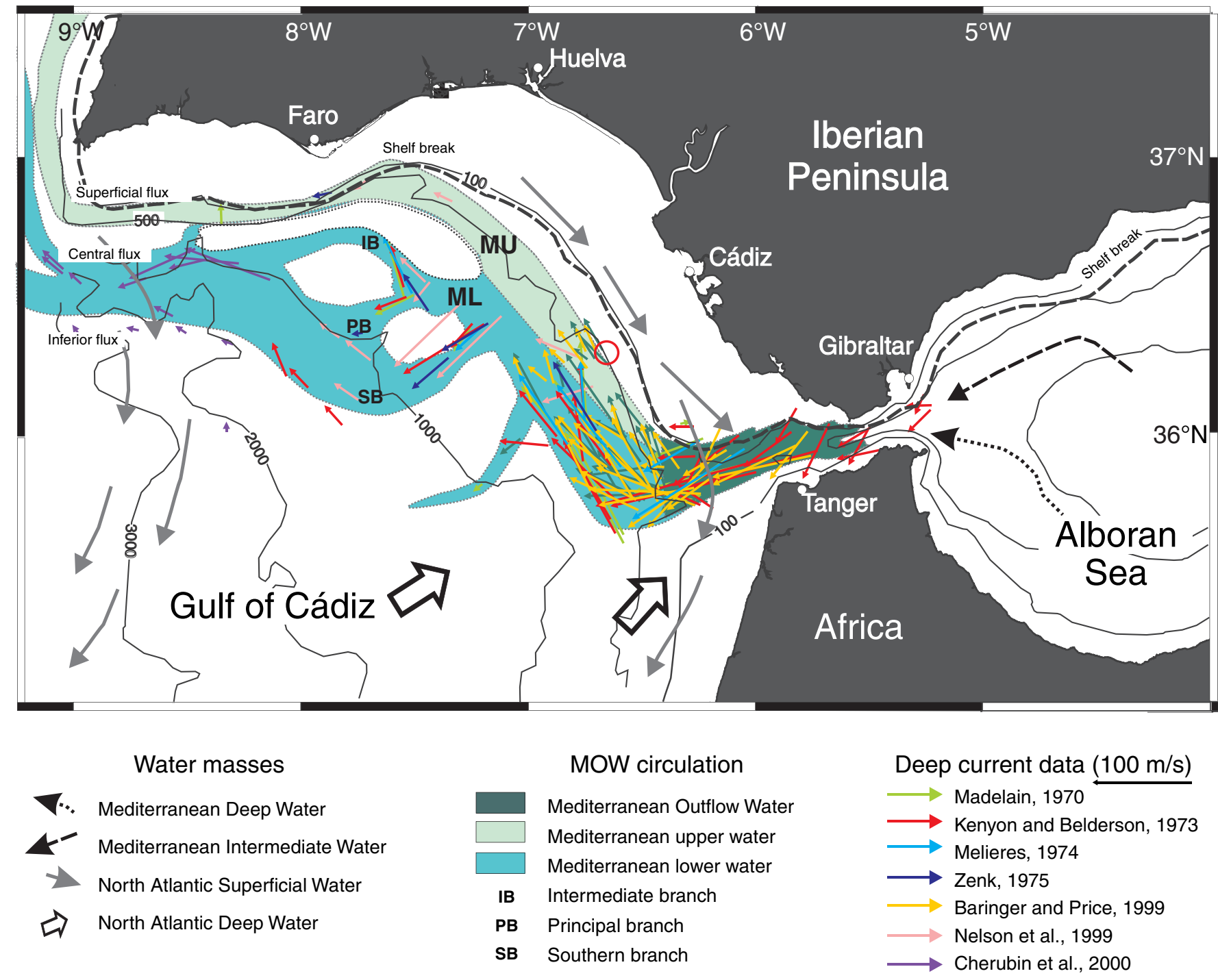


Figure F6. Graphic lithology summary log, Site U1388.

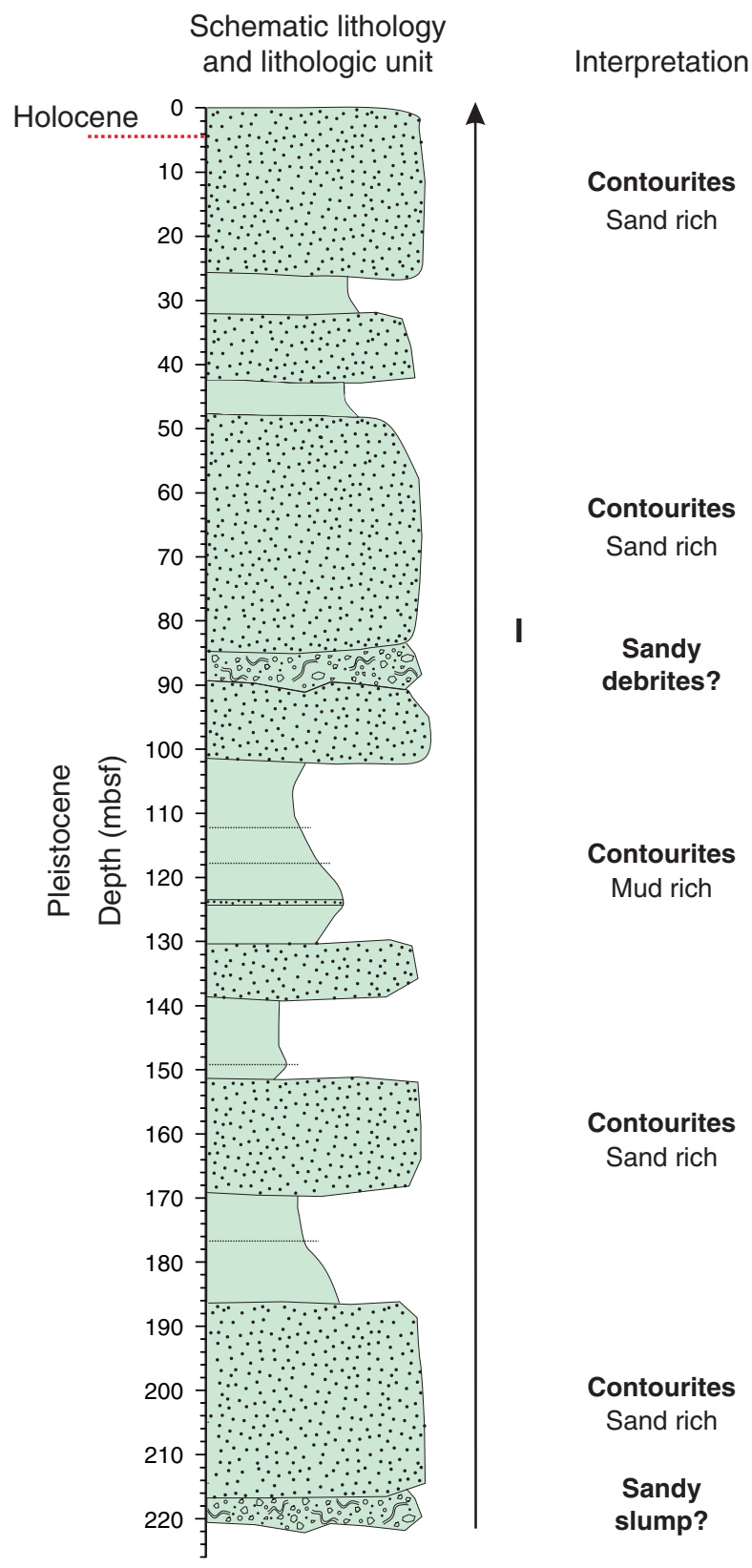


Figure F7. Plot of downhole variations in lithologies, Site U1388.

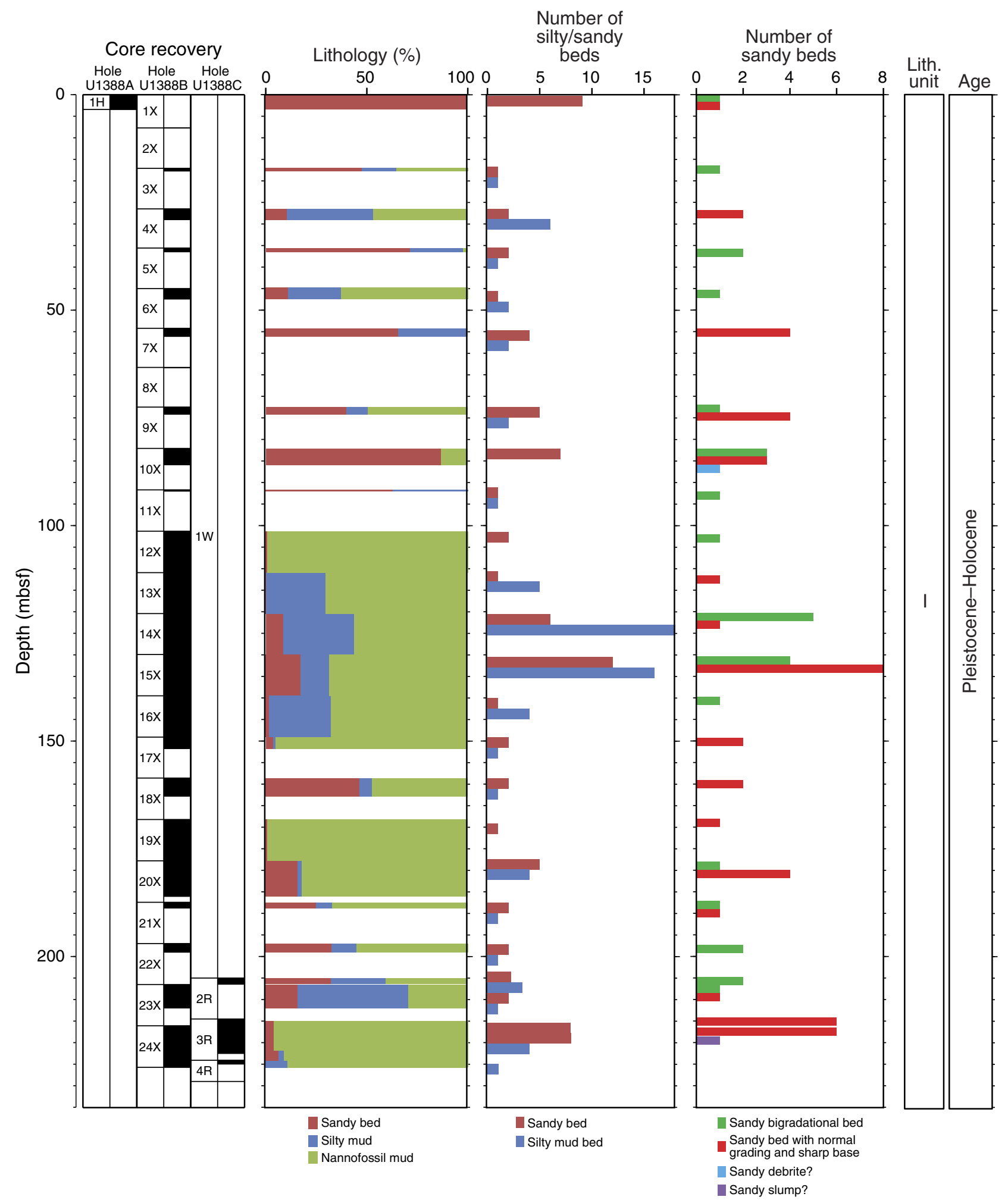


Figure F8. Plot of calcium carbonate, Holes U1388A (solid circle) and U1388B (open circles).

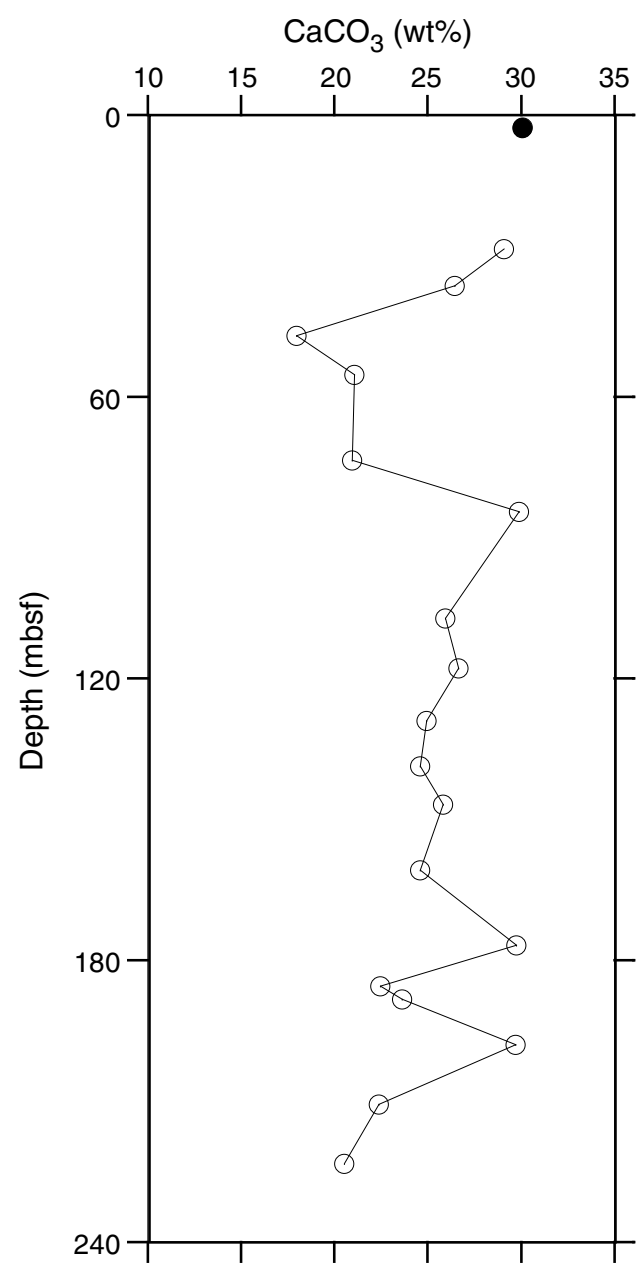


Figure F9. Graphic lithology summaries, Site U1388. A. Hole U1388A. (Continued on next two pages.)

A

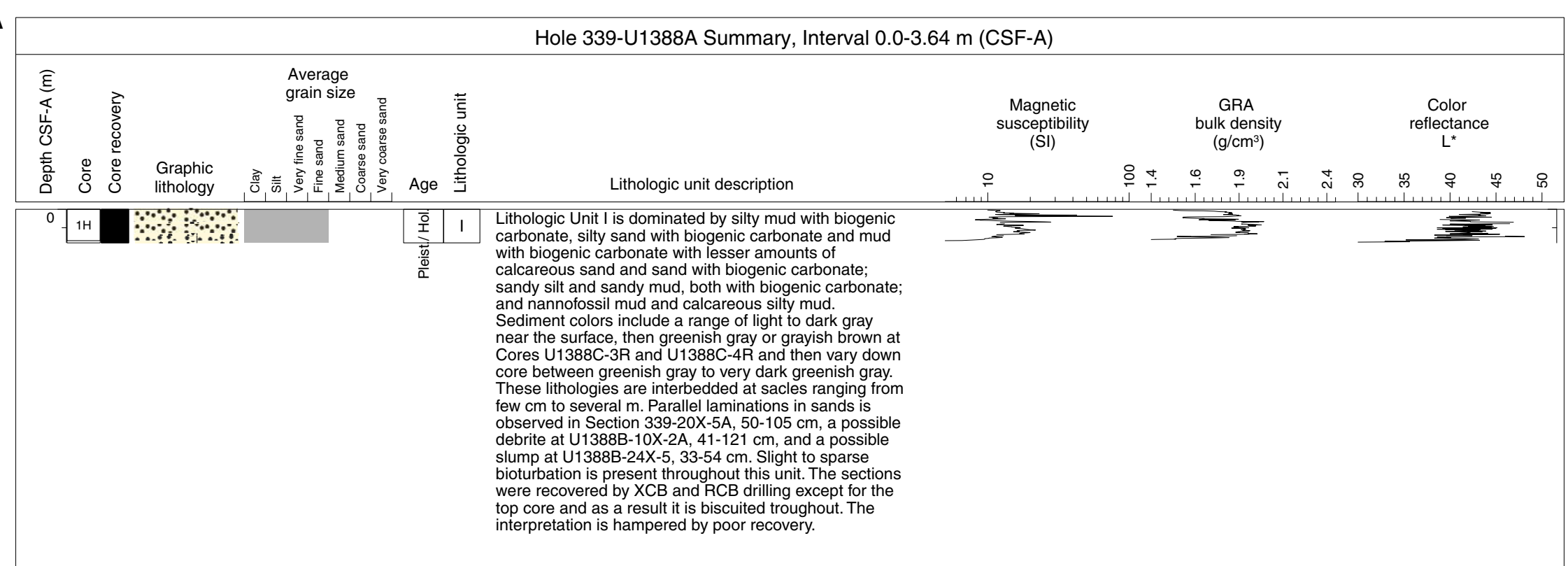


Figure F9 (continued). B. Hole U1388B. (Continued on next page.)

B

Hole 339-U1388B Summary, Interval 0.0-225.73 m (CSF-A)

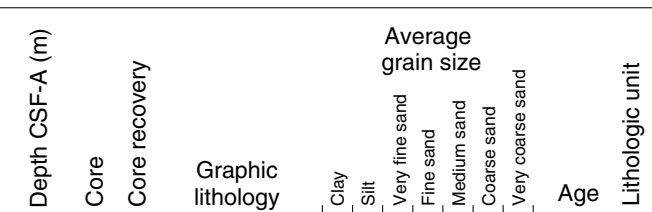
Lithologic unit description

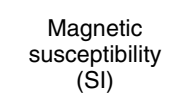

GRA
bulk density bulk density
$\left(\mathrm{g} / \mathrm{cm}^{3}\right)$

$\underset{\substack{\text { Color } \\ \text { reflectance } \\ L^{*}}}{ }$

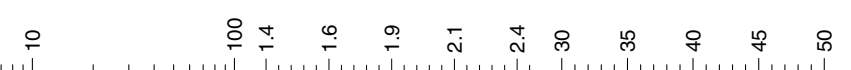

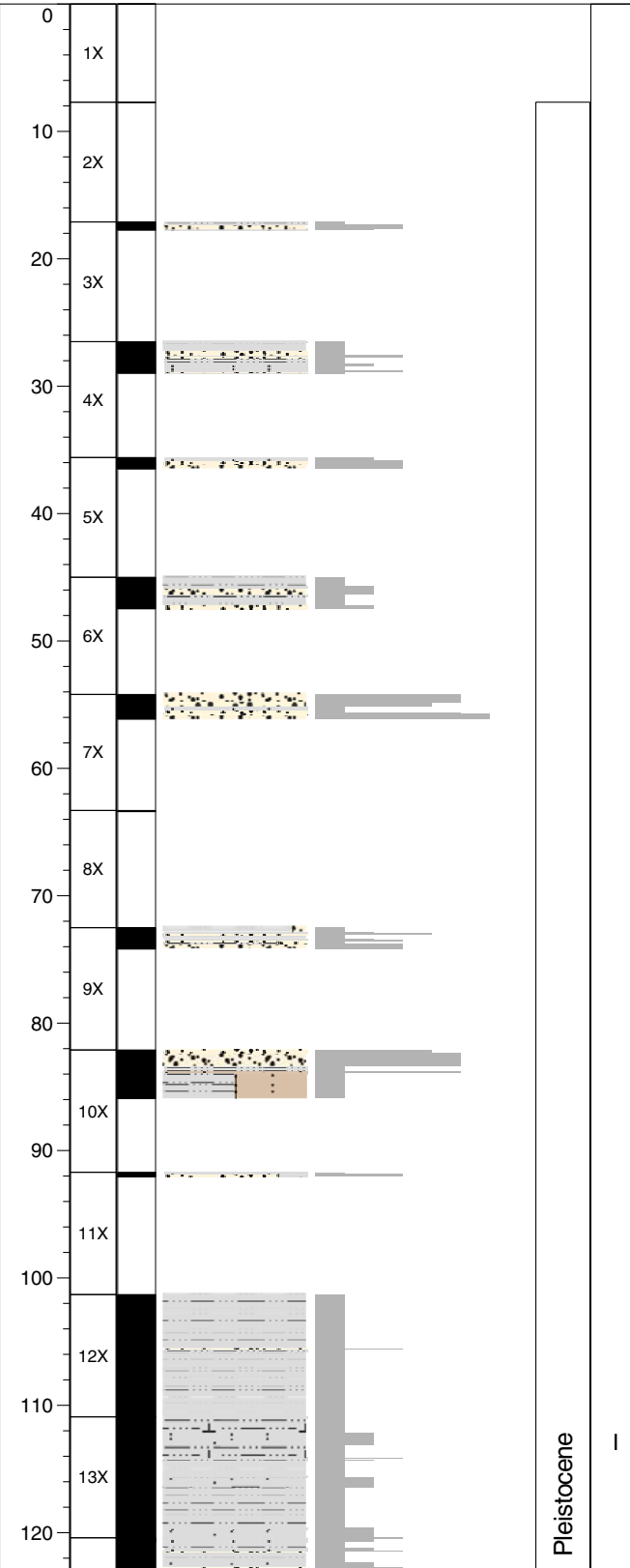

Lithologic Unit I is dominated by silty mud with biogenic carbonate, silty sand with biogenic carbonate and mud with biogenic carbonate with lesser amounts of calcareous sand and sand with biogenic carbonate; sandy sil and sandy mud, bolh with biogenic carbonate; and nannofossil mud and calcareous sity mud. near the surface, then greenish gray or grayish grown Cores U1388C-3R and U1388C-4R and then vary down core between greenish gray to very dark greenish gray. These lithologies are interbedded at sacles ranging from Tew debrite at $U 1388 B-10 X-2 A, 41-121 \mathrm{~cm}$, and apos slump at U1388B-24X-5, $33-54 \mathrm{~cm}$. Slight to sparse were recovered by XCB and RCB drilling except for the poor recovery.
piscuited throughe interpretation is hampered by poor recovery.
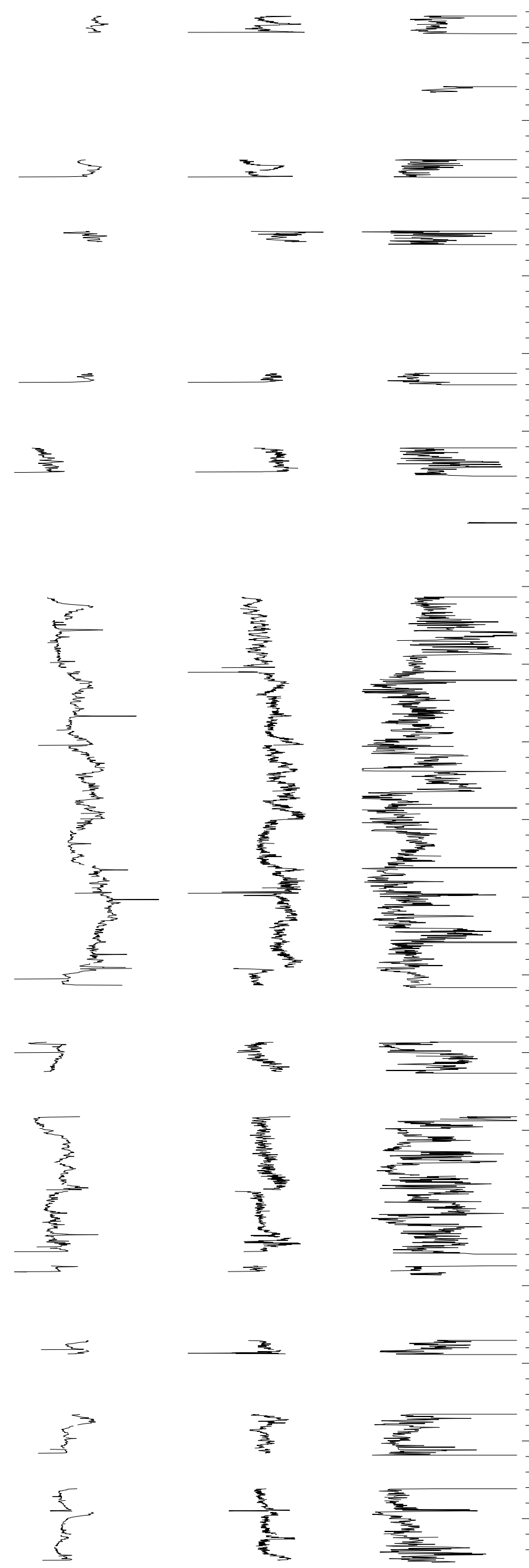

130

140

150

$-17 \times$

$+1$

$\ldots$

$170-$

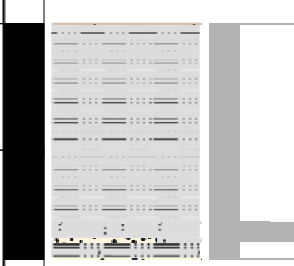

$190-$

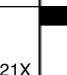

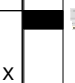

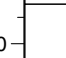

$\square \div$

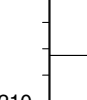

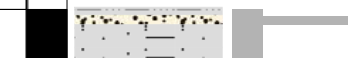

$220-24$

$+$

$\therefore$

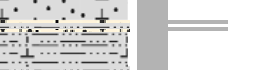


Figure F9 (continued). C. Hole U1388C

C

Hole 339-U1388C Summary, Interval 0.0-224.98 m (CSF-A)

\begin{tabular}{|c|c|c|c|c|c|c|c|c|c|c|c|c|c|c|c|}
\hline 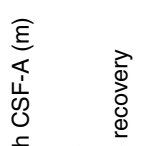 & & 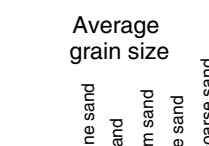 & 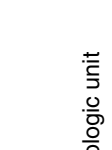 & & & & & $\begin{array}{l}\text { GRA } \\
\text { k der } \\
\mathrm{g} / \mathrm{cm}\end{array}$ & & & & & $\begin{array}{l}\text { Color } \\
\text { lectance } \\
\mathrm{L}^{*}\end{array}$ & & \\
\hline 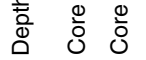 & $\begin{array}{l}\text { Graphic } \\
\text { lithology }\end{array}$ & 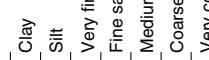 & Age $\stackrel{\bar{D}}{\underline{\Xi}}$ & Lithologic unit description & $\stackrel{\circ}{1}$ & $\stackrel{\circ}{\stackrel{5}{5}}$ & $\stackrel{\circ}{\leftarrow}$ & $\stackrel{?}{\longrightarrow}$ & $\overline{\mathrm{i}}$ & $\stackrel{\text { i }}{\mathrm{N}}$ & 8 & $\stackrel{\infty}{\infty}$ & g & \& & 品 \\
\hline
\end{tabular}

10

30

40

50

70

80

90

$130-$

140

$150-$

$160-$

$170-$

$180-$

190

$200-$

$2 \mathrm{R}$

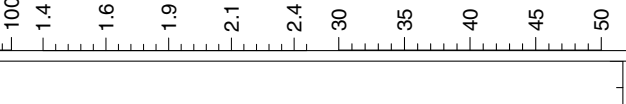

.

iw

carbonate and mud

with biogenic carbonate with lesser amounts of
calcareous sand and sand with biogenic carbonate; sandy

giogenic carbonate; sandy
silty mud.

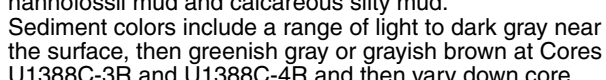

between greenish gray to very dark greenish gray

These lithologies are interbedded at sacles ranging from

few $\mathrm{cm}$ to several $\mathrm{m}$. Parallel laminations in sands is
observed in Section $339-20 \mathrm{X}-5 \mathrm{~A}, 50-105 \mathrm{~cm}$, a possible

debrite at U1388B-10X-2A, 41-121 cm, and a possible

slump at U1388B-24X-5, 33-54 cm. Slight to sparse

bioturbation is present throughout this unit. The section

op core and as a result it is biscuited troughout. The

interpretation is hampered by poor recovery. 
Figure F10. Plot of percentage of coarser beds (sandy and silty beds) relative to the total thickness cored and relative to the total thickness recovered. If the sediment not recovered by XCB drilling in the upper $100 \mathrm{~m}$ of Hole U1388B is primarily muds and silty muds, then the abundances of coarser and finer lithologies are relatively uniform through the entire section at Site U1388. If the unrecovered sediments above $\sim 100$ mbsf are primarily sands and silts, then coarser lithologies are significantly more abundant in the upper $100 \mathrm{~m}$ of the section.

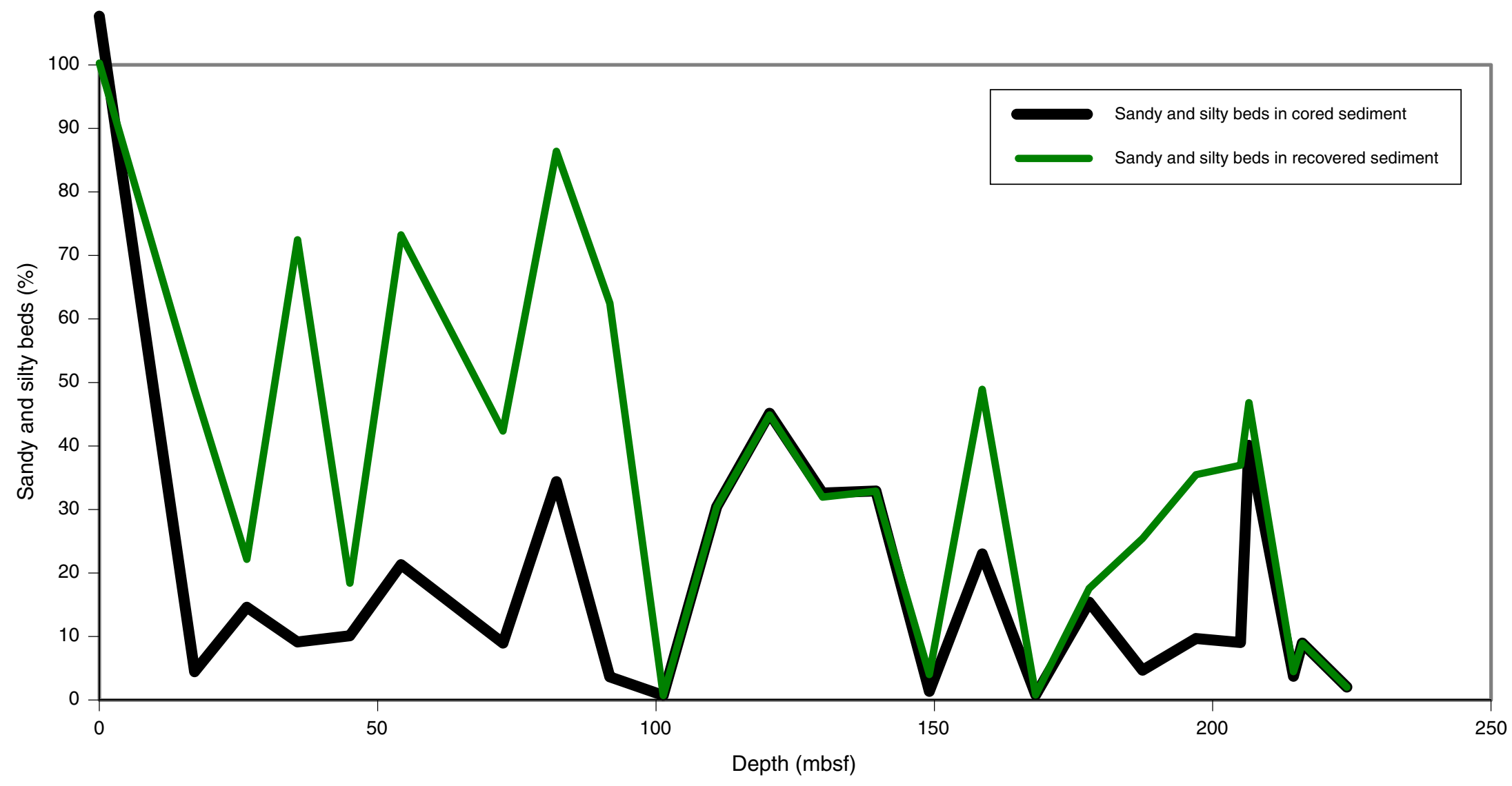


Figure F11. Core image of a contourite bed (Section 339-U1388B-16X-13A). Pink material visible in places on the core surface is drilling mud.

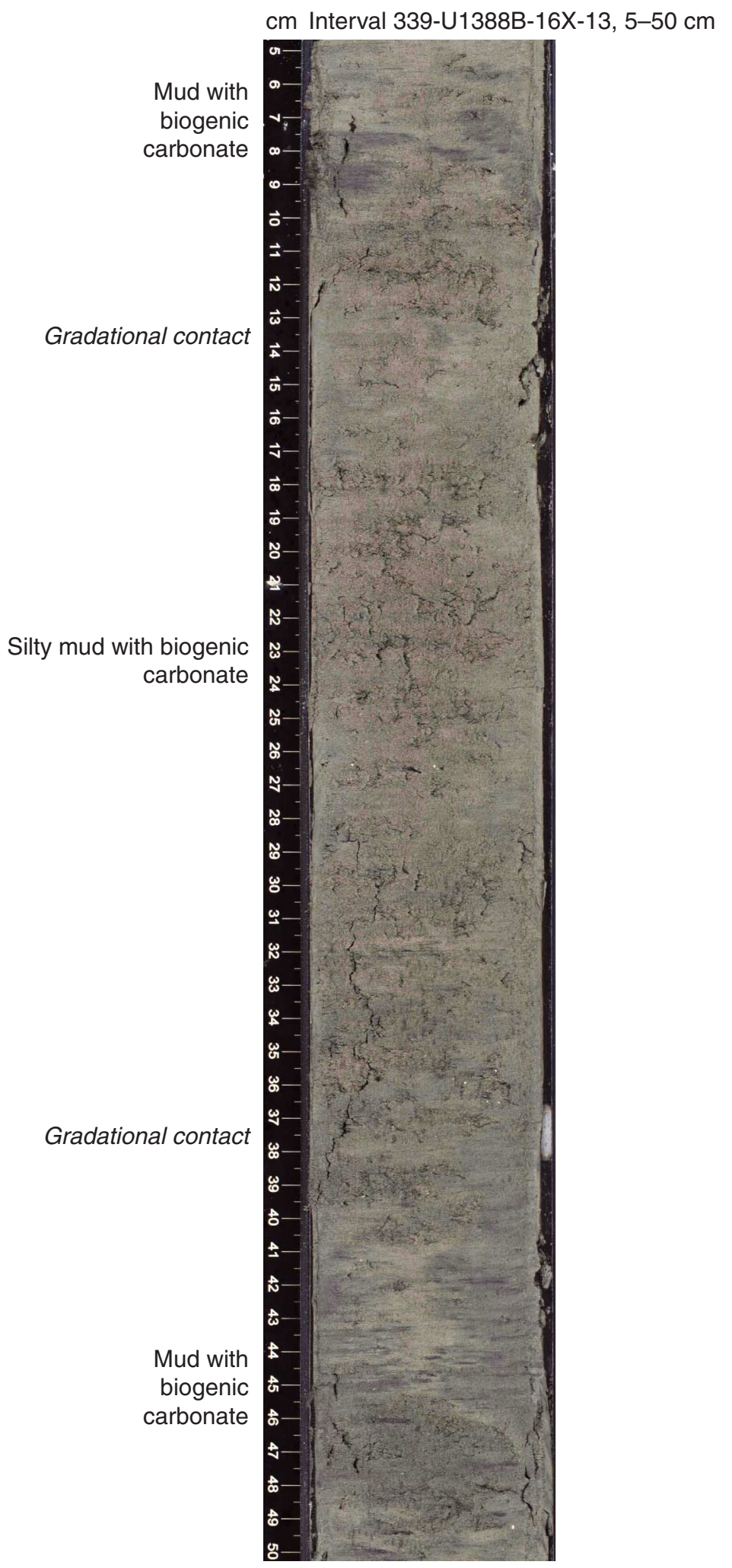


Figure F12. Core image of a sharp basal contact (Section 339-U1388B-19X-1A).

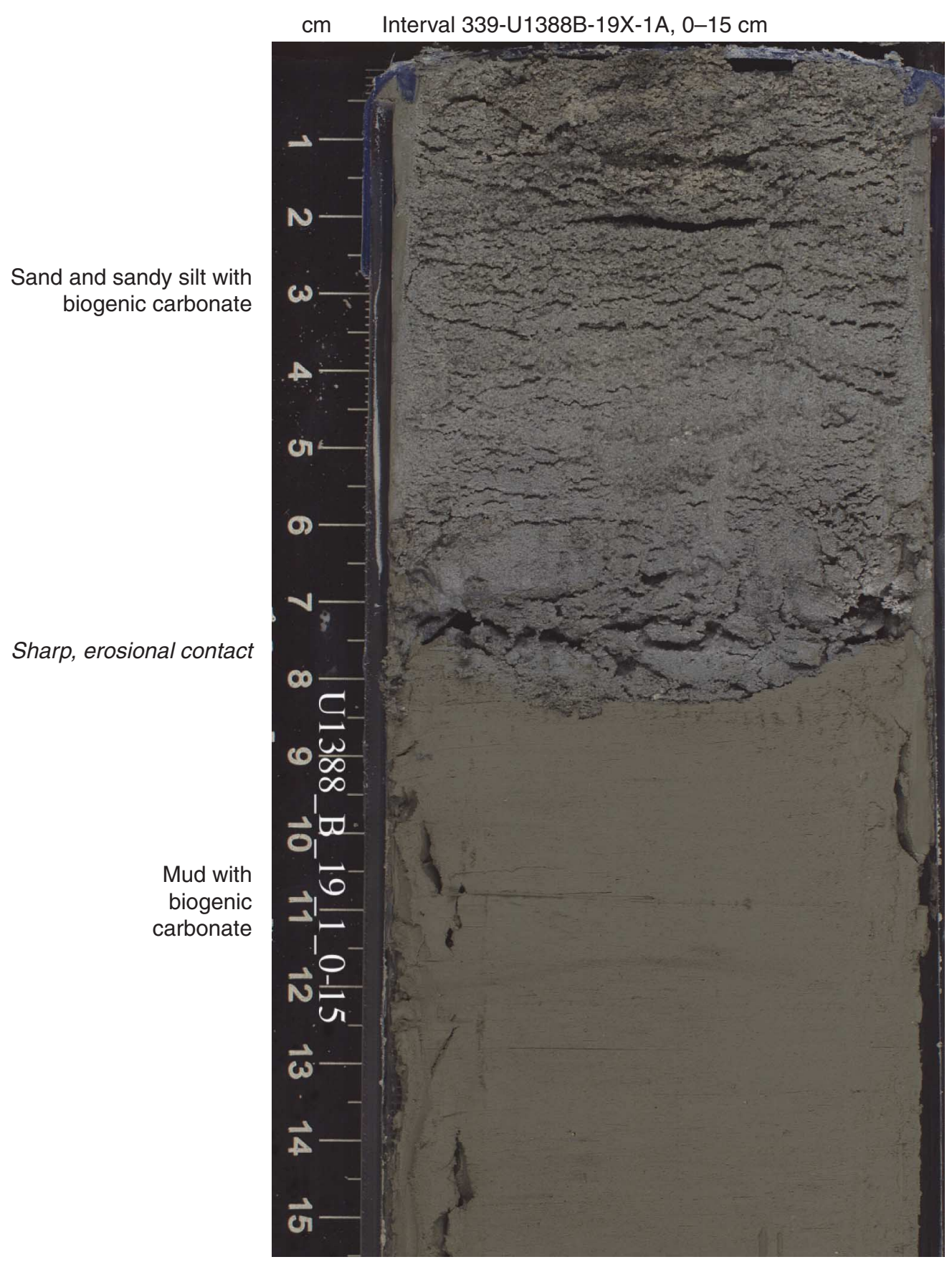


Figure F13. Core image of an inversely graded bed (Section 339-U1388C-3R-2A).

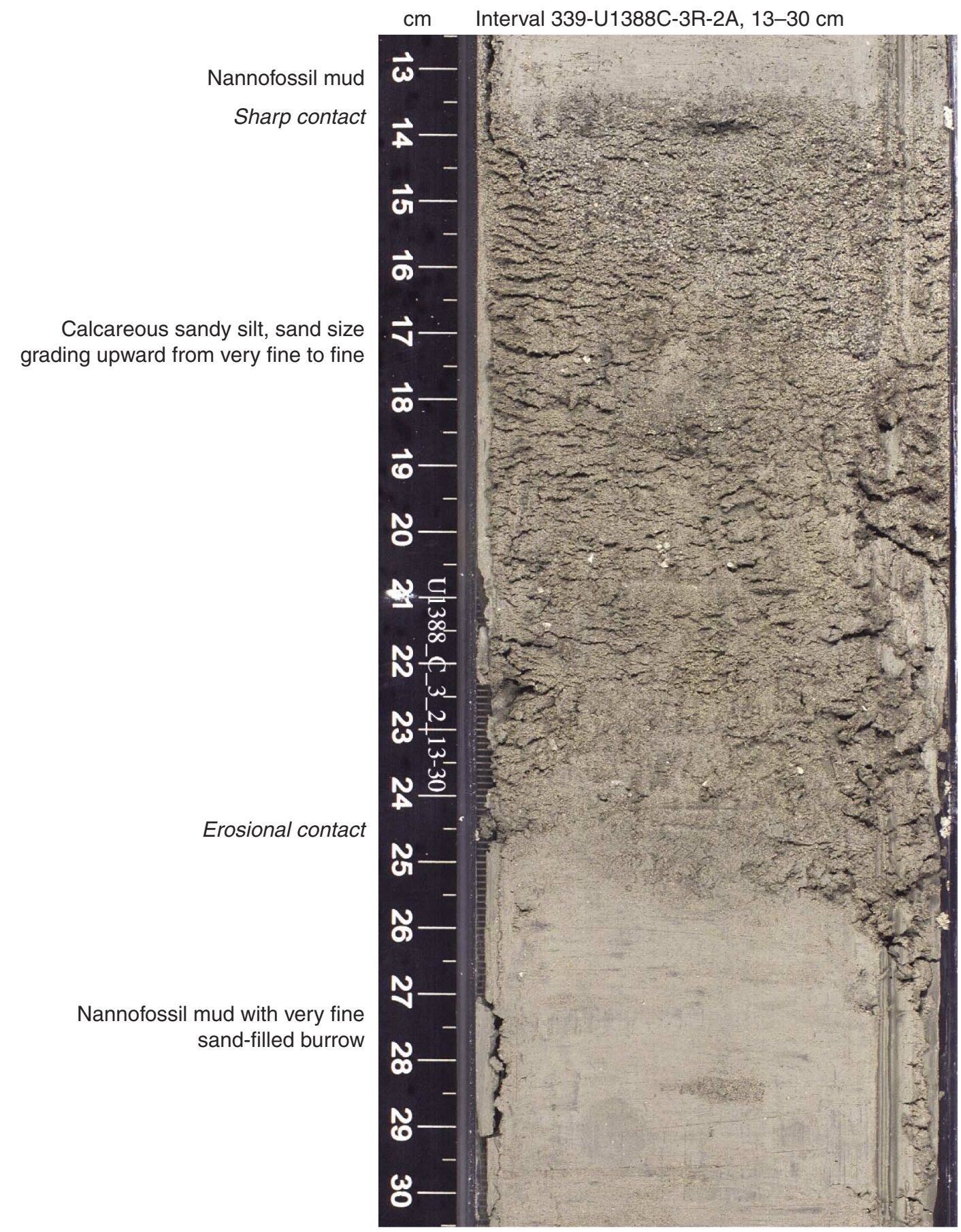


Figure F14. Core image of an inversely graded bed (Section 339-U1388C-3R-4A).

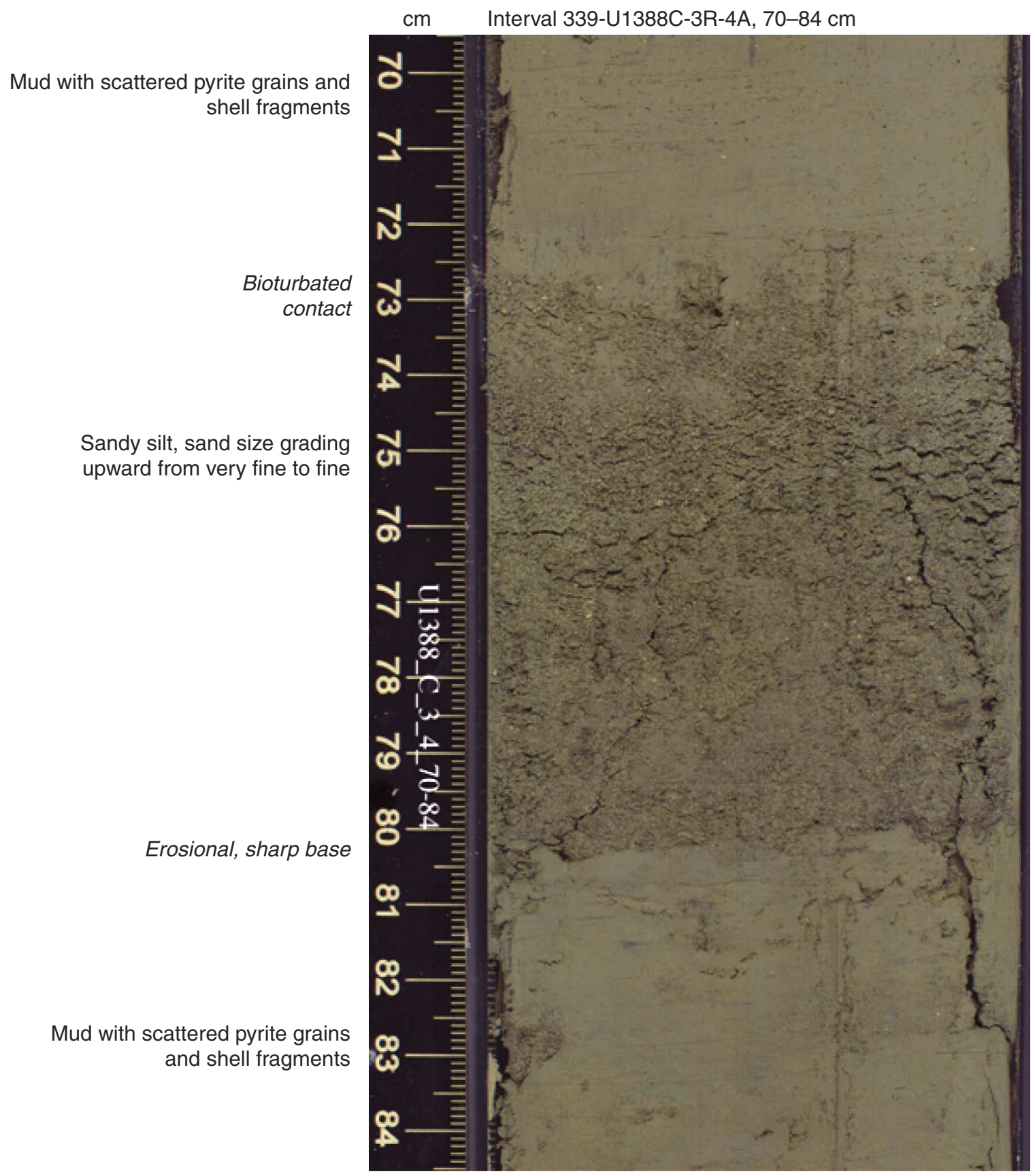


Figure F15. Core image of an inversely graded bed (Section 339-U1388C-3R-5A).

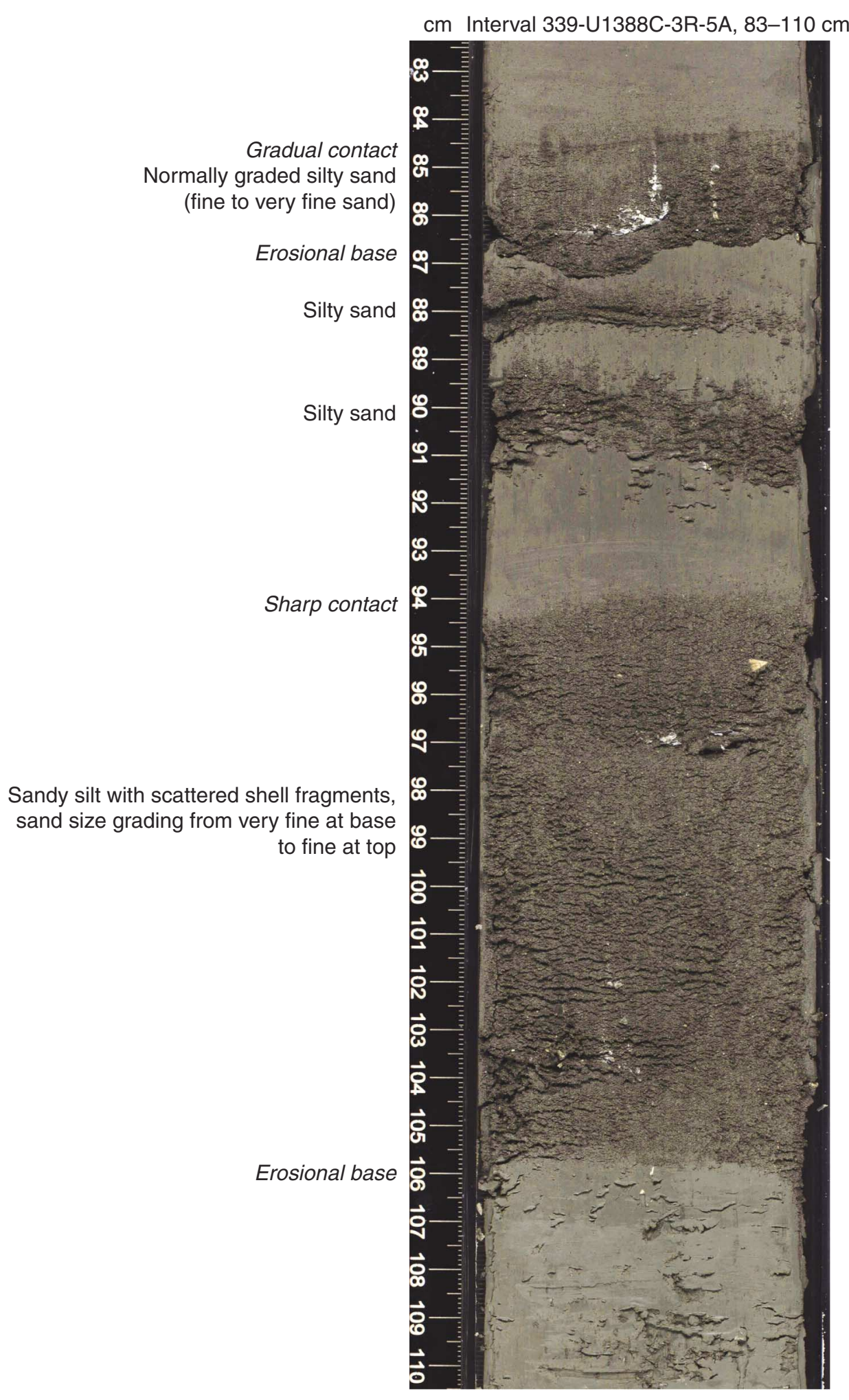


Figure F16. Core image of laminated sand and mud, including light sand laminations interbedded with other sand and mud (Section 339-U1388B-20X-5A).

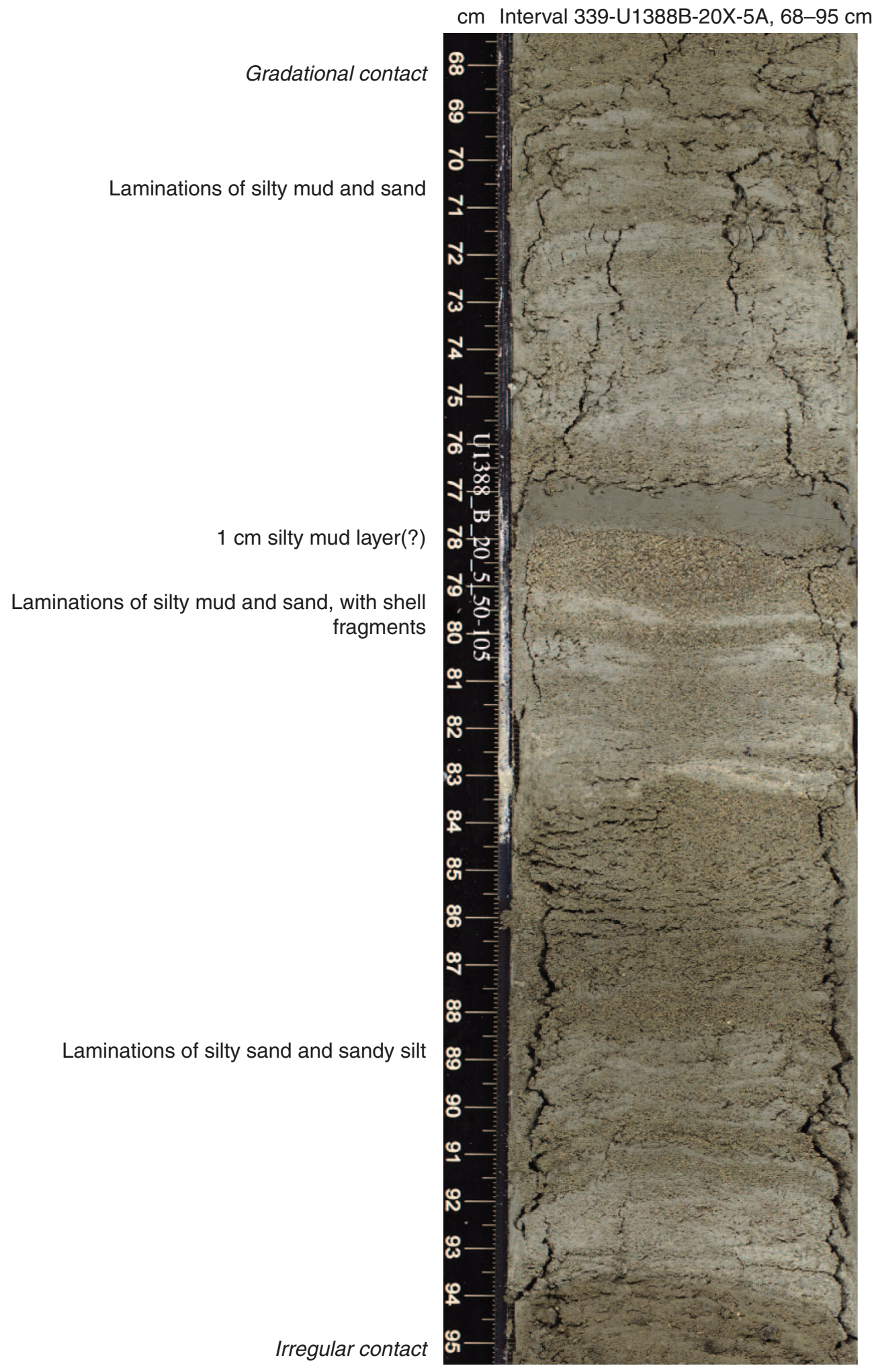


Figure F17. Core images of two likely mass transport deposits. A. Slump deposit (Section 339-U1388B-10X-2A). B. Debris-flow deposit (Section 339-U1388B-24X-5A).

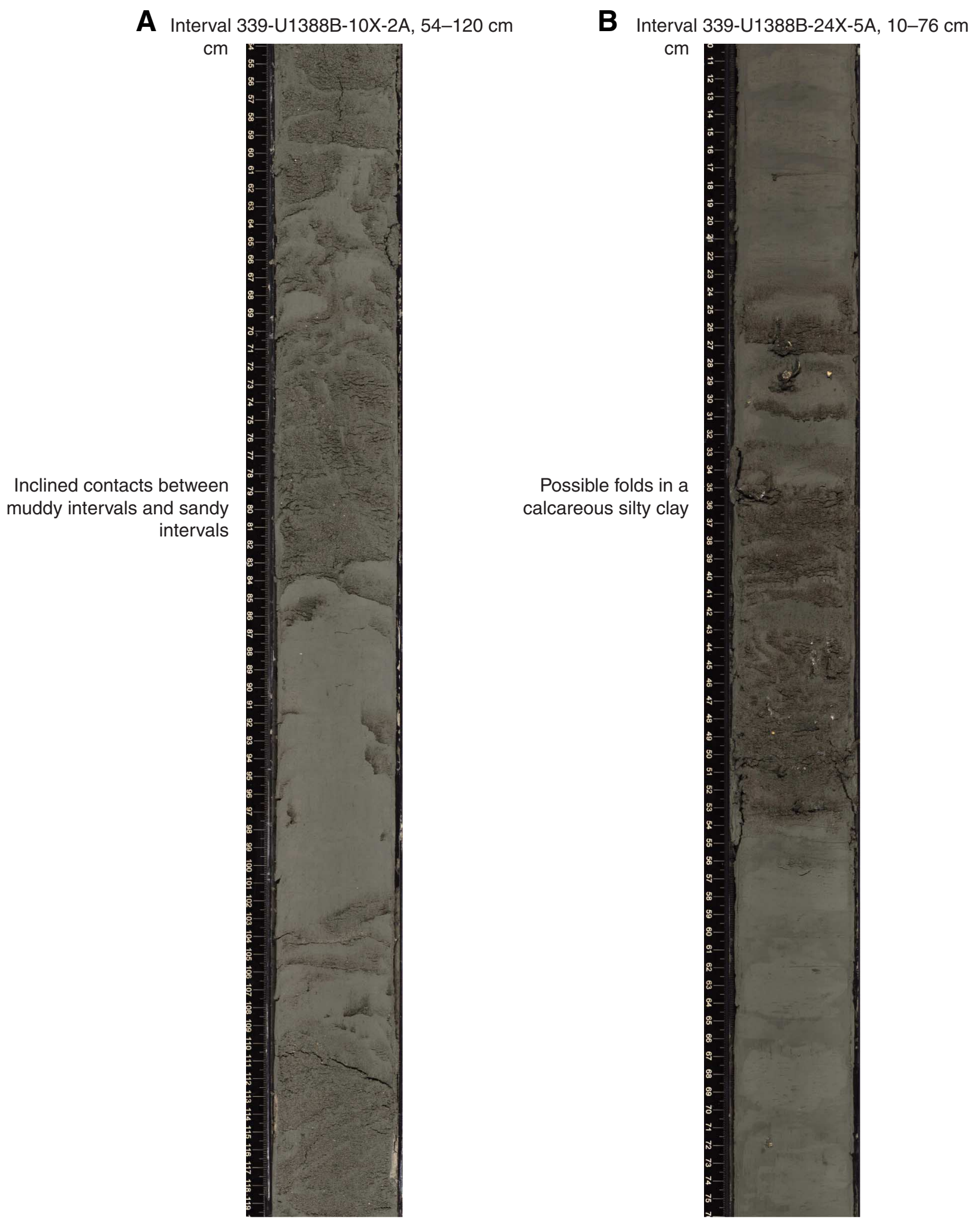


Figure F18. Photomicrographs of mineral grains in smear slides. The smear slides show relatively similar compositions; identified minerals include quartz and detrital carbonate, which are common. Biogenic carbonate (foraminiferal fragments and nannofossils) and feldspar, mica, dolomite, hypersthene, hornblende, glauconite, and zircon are present to rare. Pyrite is also observed. A. Turbidite (Sample 339-U1388B-7X-1, $9 \mathrm{~cm}$ ). B. Contourite (Sample 339-U1388B-10X-1, $100 \mathrm{~cm}$ ). Upper panels taken under transmitted light; lower panels taken under cross-polarized light.
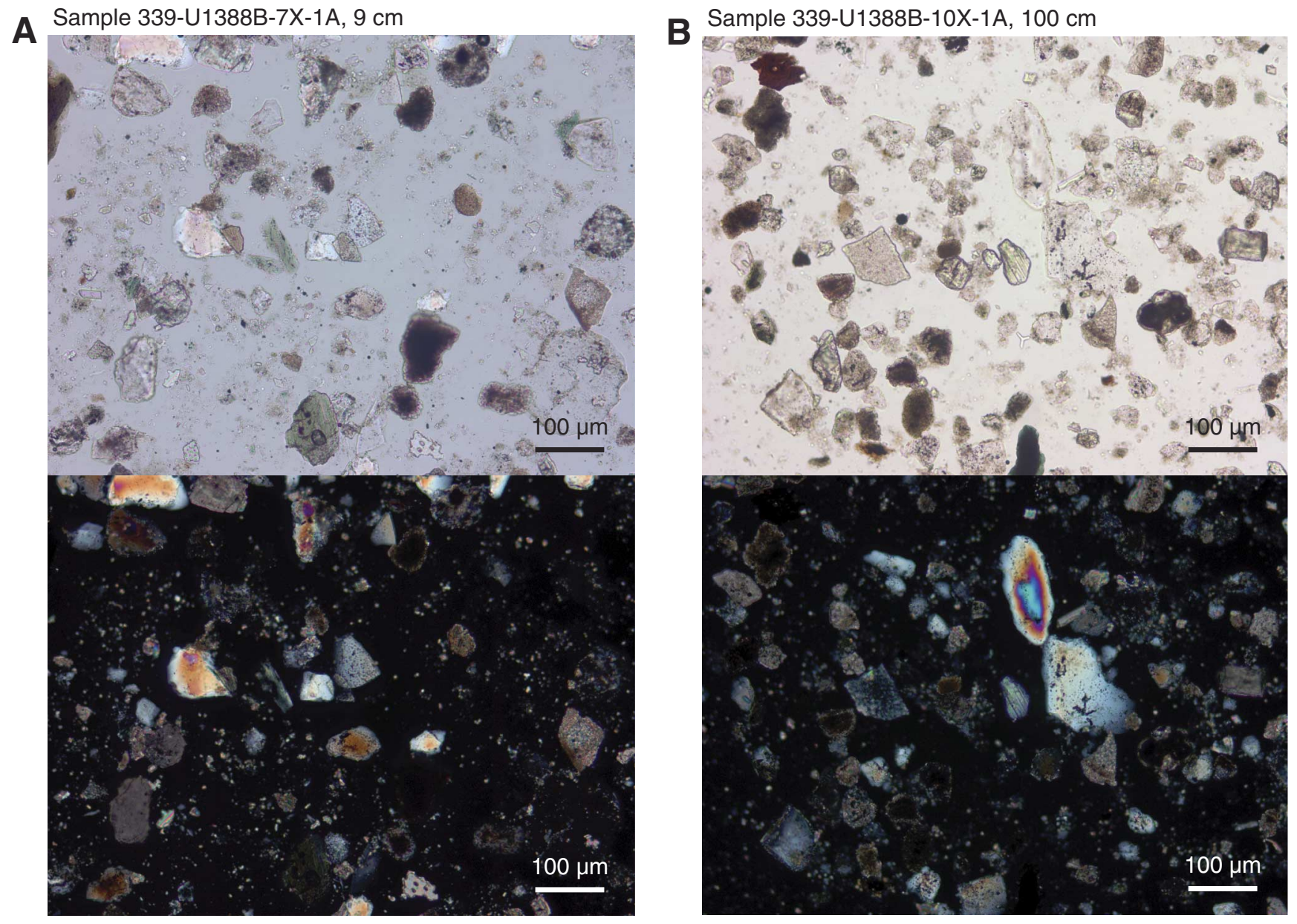
Figure F19. Photographs of three complete, well-preserved gastropods (Samples 339-U1388B-10X-CC and 19X2-PAL, and 339-U1388A-1H-3A, 48-49 cm).
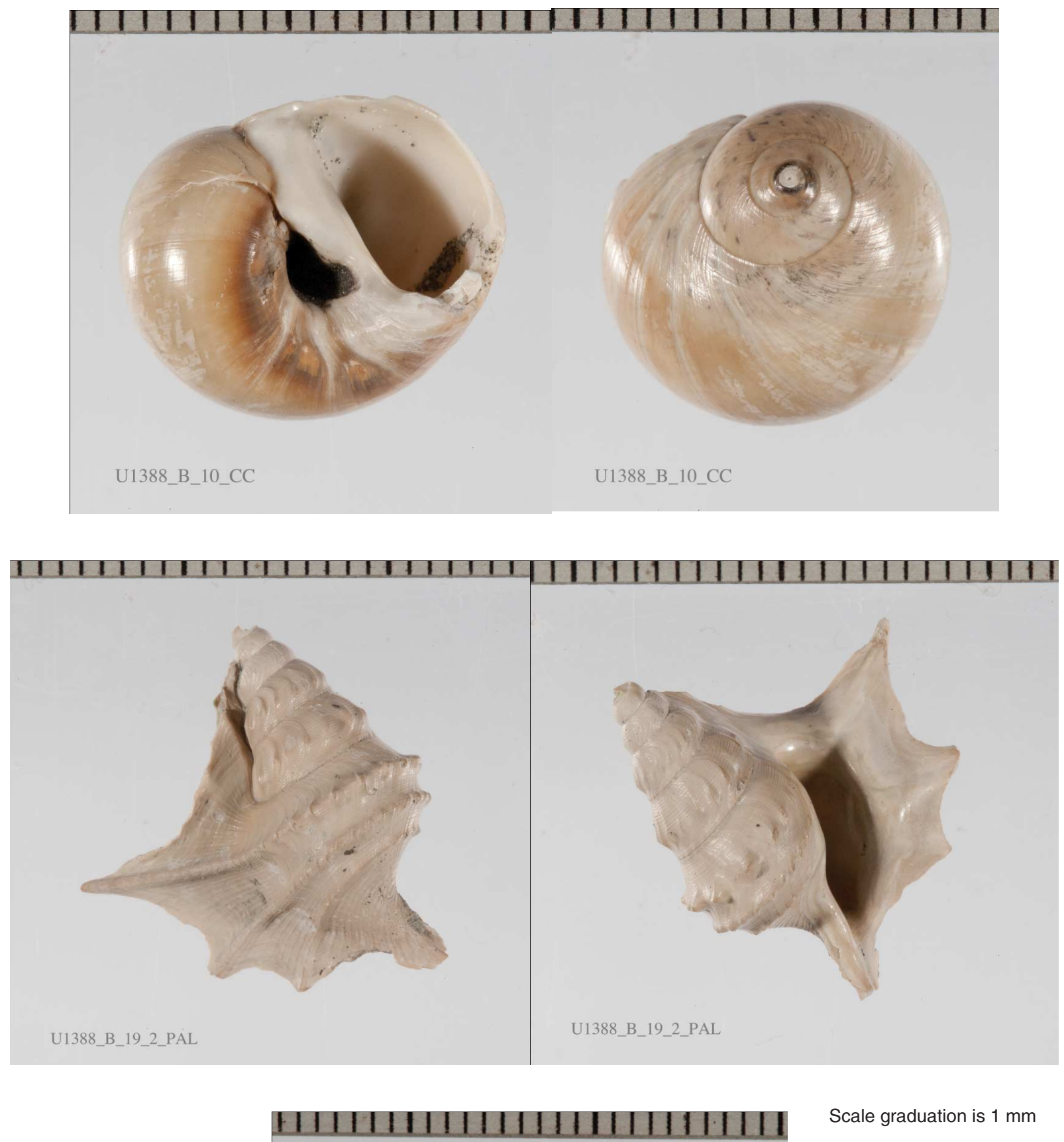


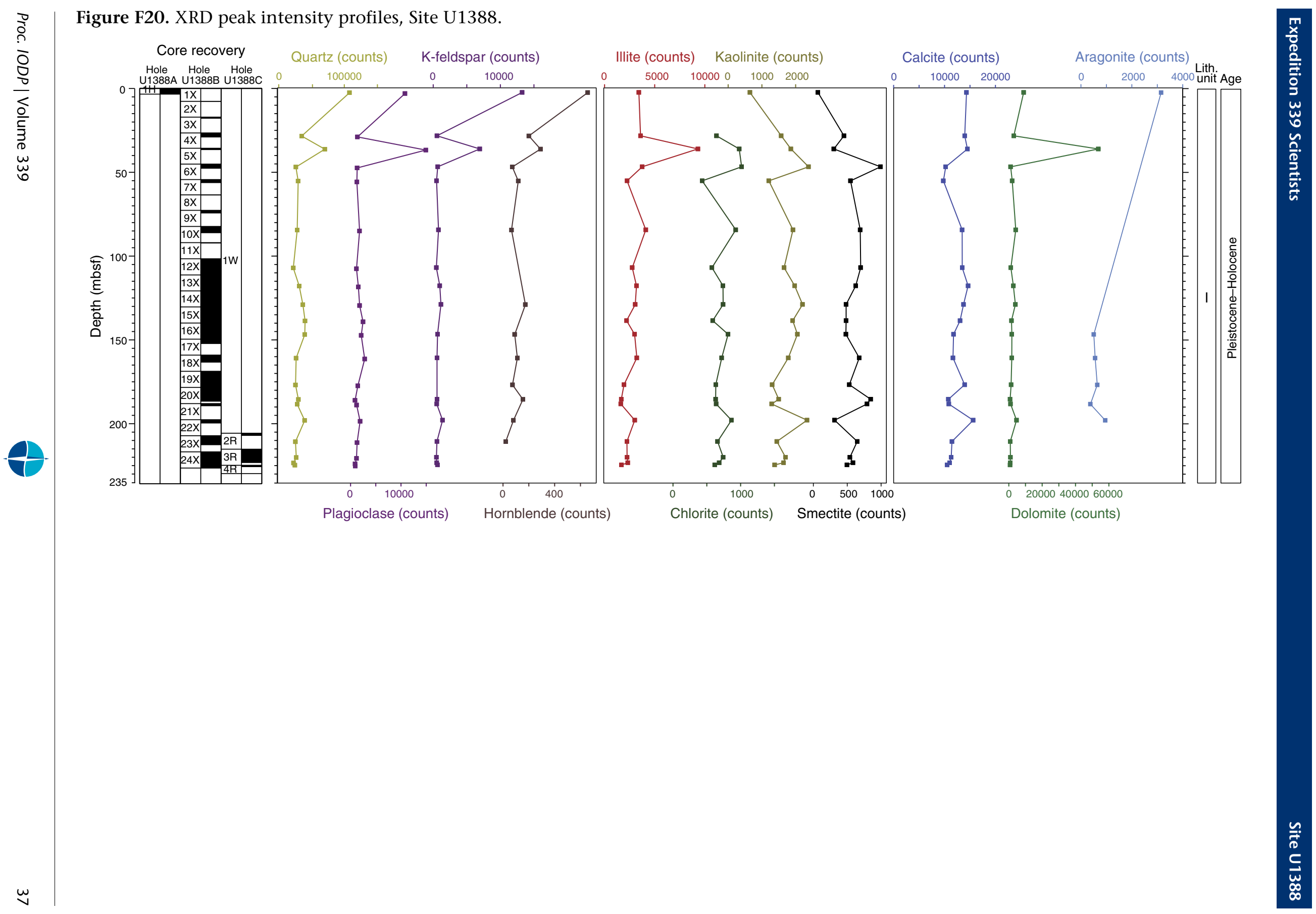


Figure F21. XRD patterns of bulk nonglycolated (black) and ethylene glycolated (red) sediment samples, Site U1388. Downhole changes in clay-mineral abundance have not been quantified, but note that low-angle peak generally shifts to lower angles and becomes more intense as a result of glycolation. This suggests the presence of poorly crystalline smectite.
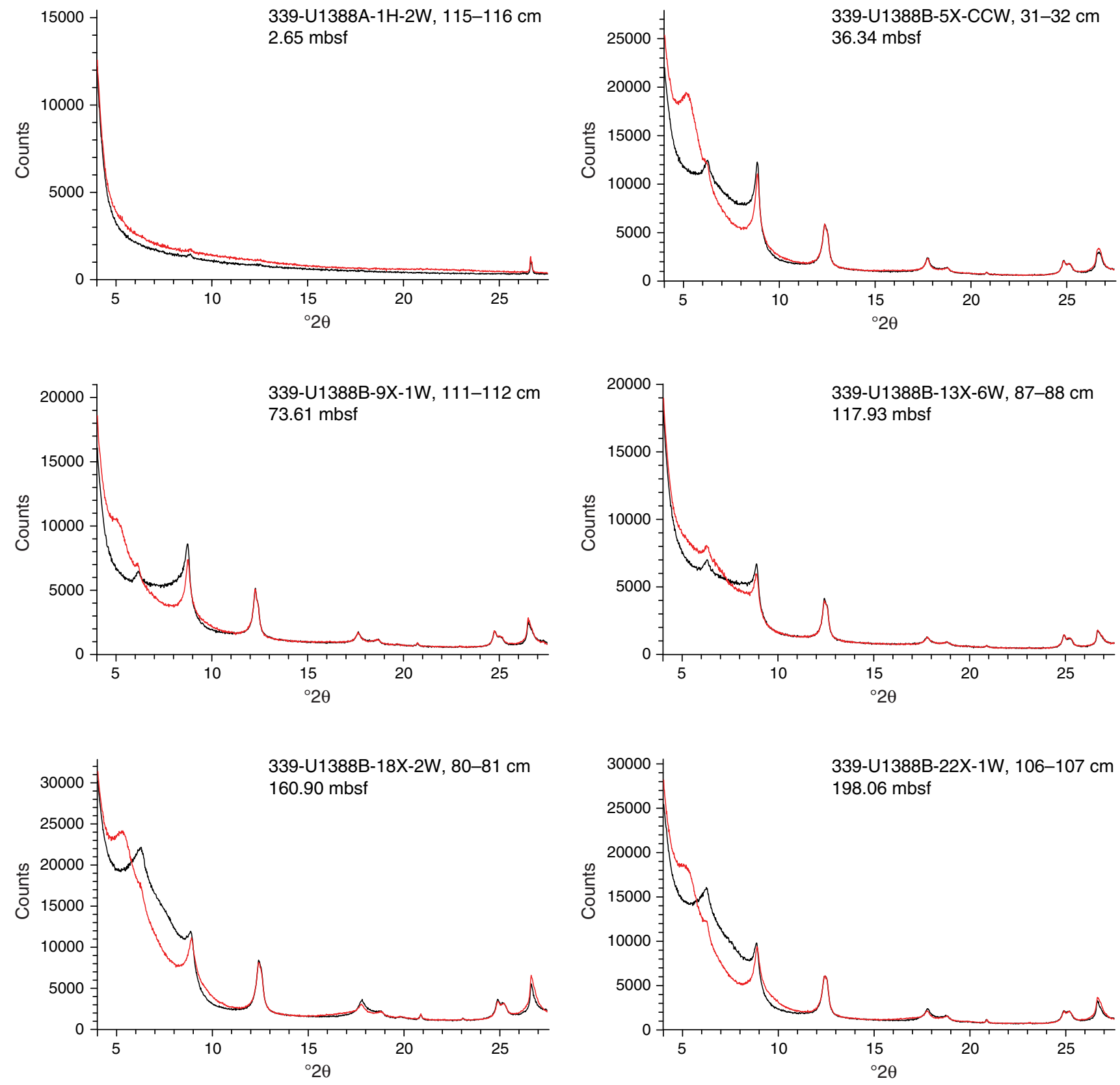
Figure F22. Paleomagnetism after $20 \mathrm{mT}$ AF demagnetization, Site U1388. Blue triangles = discrete sample locations. Yellow circles $=$ component inclinations of discrete samples with maximum angular deviation mostly less than $10^{\circ}$. In Chron columns, black $=$ normal polarity, white $=$ reversed polarity, and gray $=$ zones without a clear magnetostratigraphic interpretation. In Inclination columns, blue dashed lines $=$ expected geocentric axial dipole inclinations at the site latitude during reversed (left) and normal (right) polarities. In Susceptibility columns, gray lines indicate SHMSL susceptibility plus $25 \times 10^{-5}$ volume SI to better show the comparison with WRMSL susceptibility (black lines). A. Hole U1365A. (Continued on next two pages.)

A

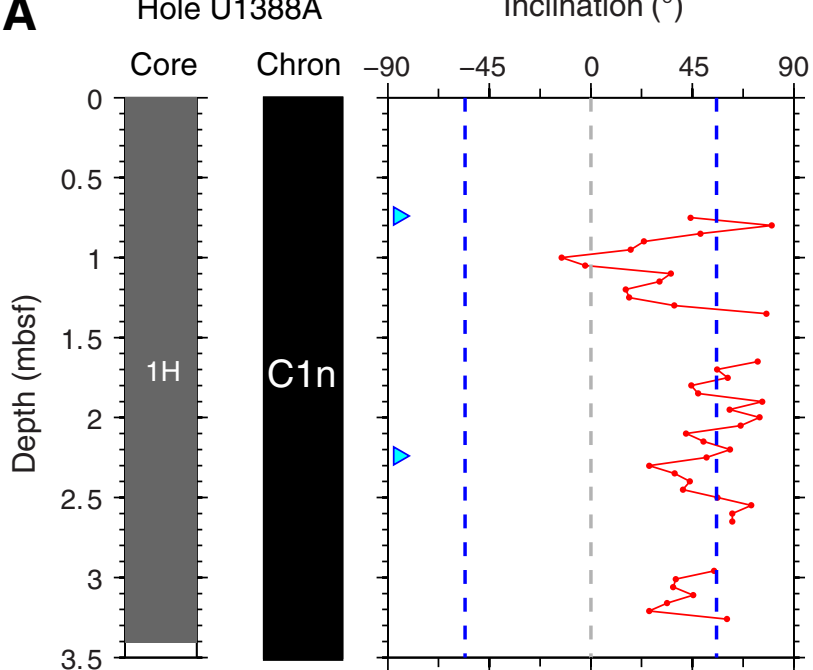

Declination $\left(^{\circ}\right)$

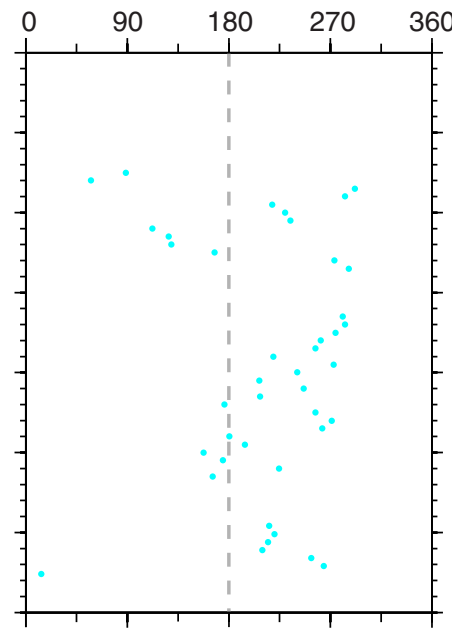

Intensity $(\mathrm{A} / \mathrm{m})$

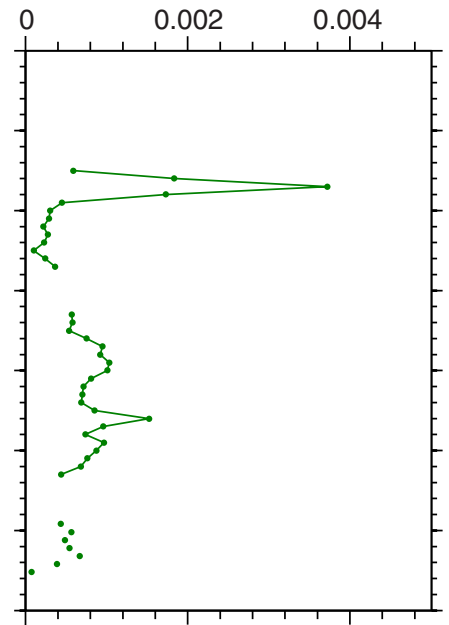

Susceptibility $\left(10^{-5} \mathrm{SI}\right)$

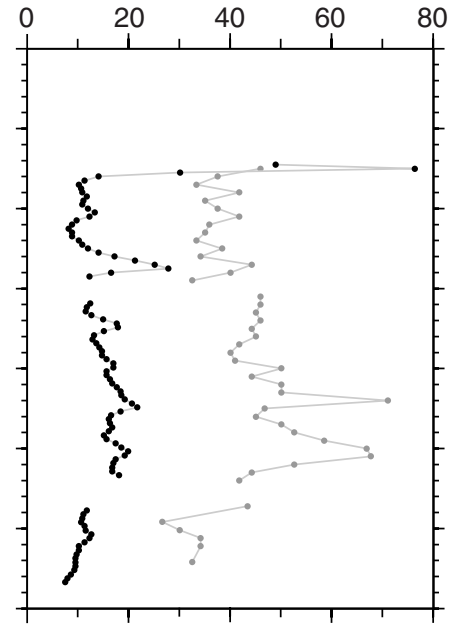


Figure F22 (continued). B. Hole U1388B. (Continued on next page.)

$$
\text { B Hole U1388B Inclination }\left({ }^{\circ}\right) \quad \text { Declination }\left({ }^{\circ}\right)
$$

Intensity $(\mathrm{A} / \mathrm{m})$

Susceptibility $\left(10^{-5} \mathrm{SI}\right)$
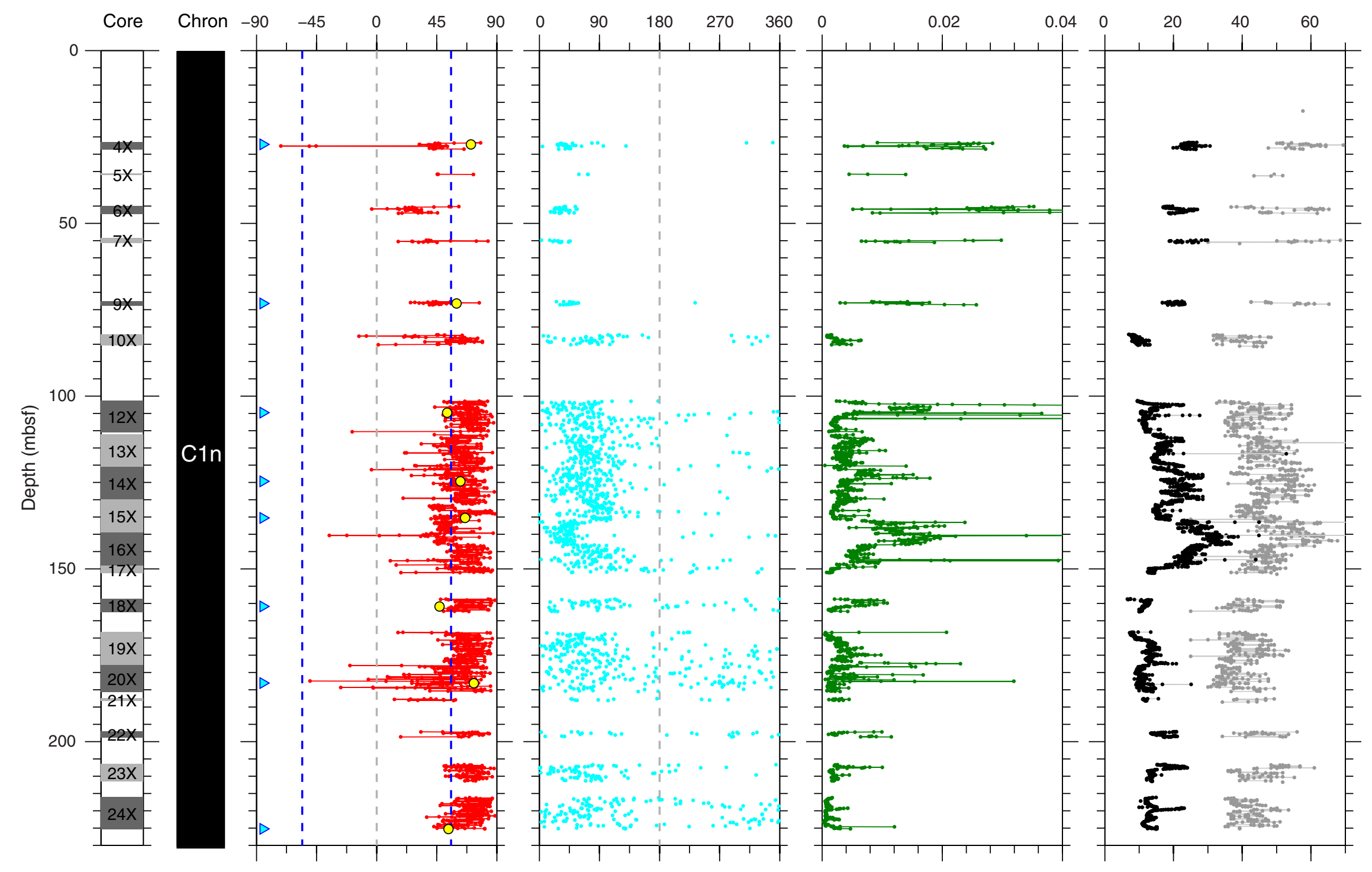


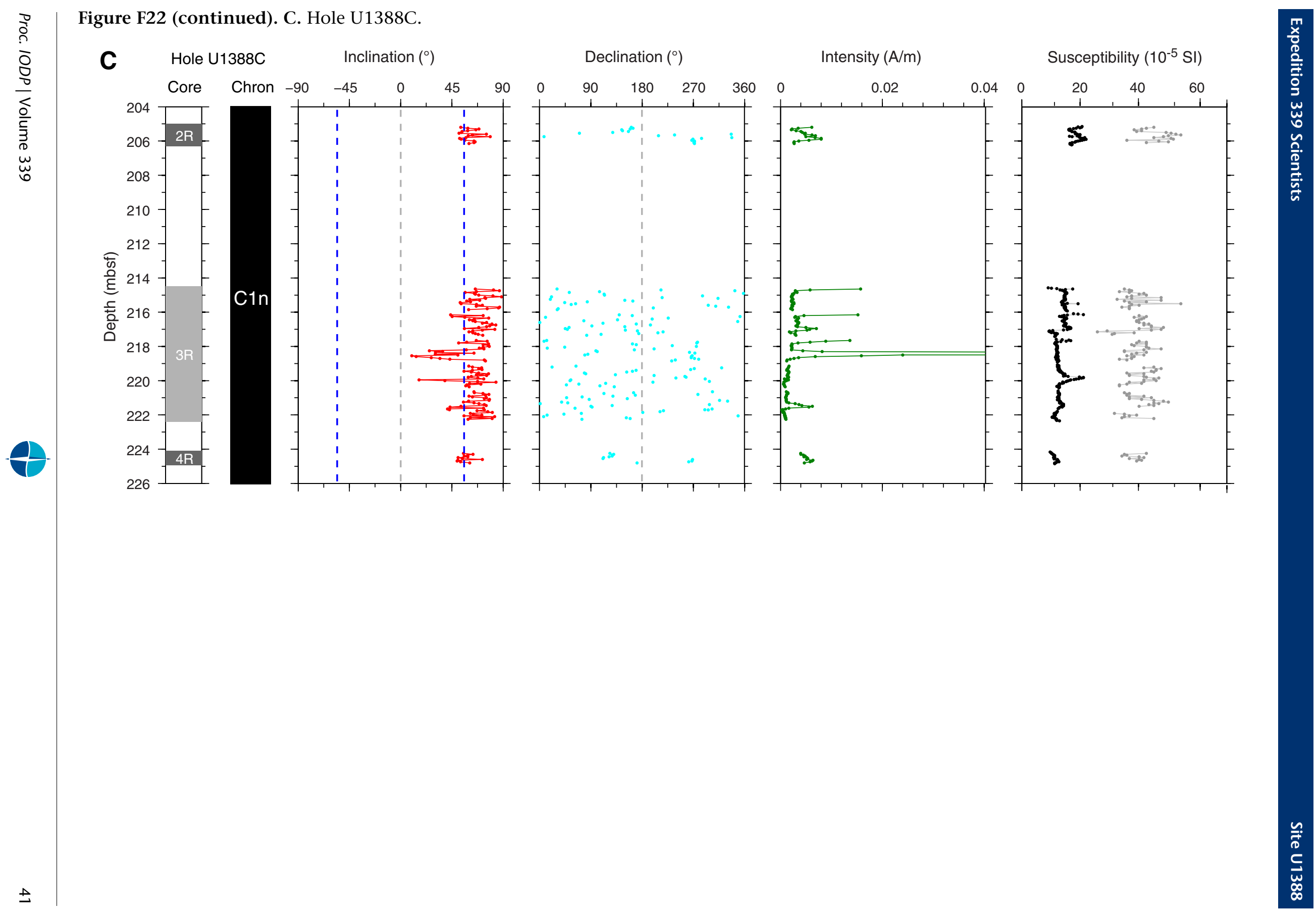


Figure F23. AF demagnetization results for eight discrete samples, Hole U1388B. For each sample, the right plot shows the vector endpoints of paleomagnetic directions measured after each demagnetization treatment on an orthogonal projection (Zijderveld) plot. Squares $=$ horizontal projections, circles $=$ vertical projections. The left plot shows the intensity variation with progressive demagnetization. Orthogonal projection plots illustrate the removal of a steep drilling overprint by $\sim 15-20 \mathrm{mT}$ peak field AF demagnetization and a significant amount of ARM acquisition during high-peak field ( $>55 \mathrm{mT}$ ) AF demagnetization, with the remaining magnetization providing a well-resolved characteristic remanent magnetization.
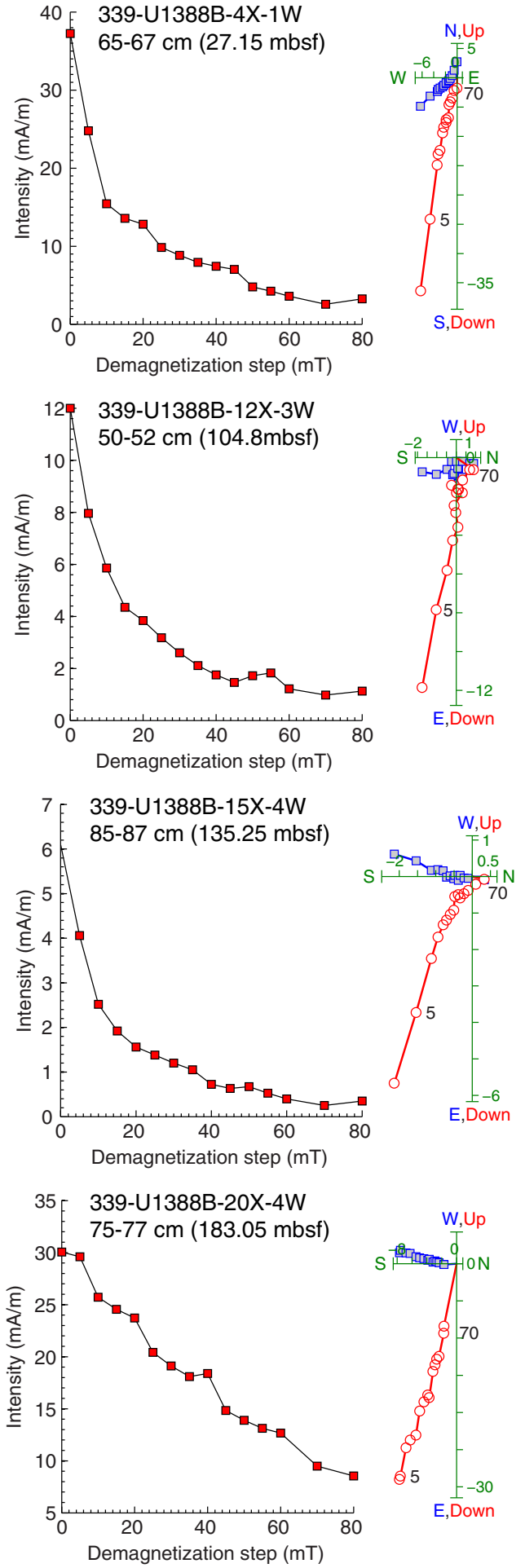
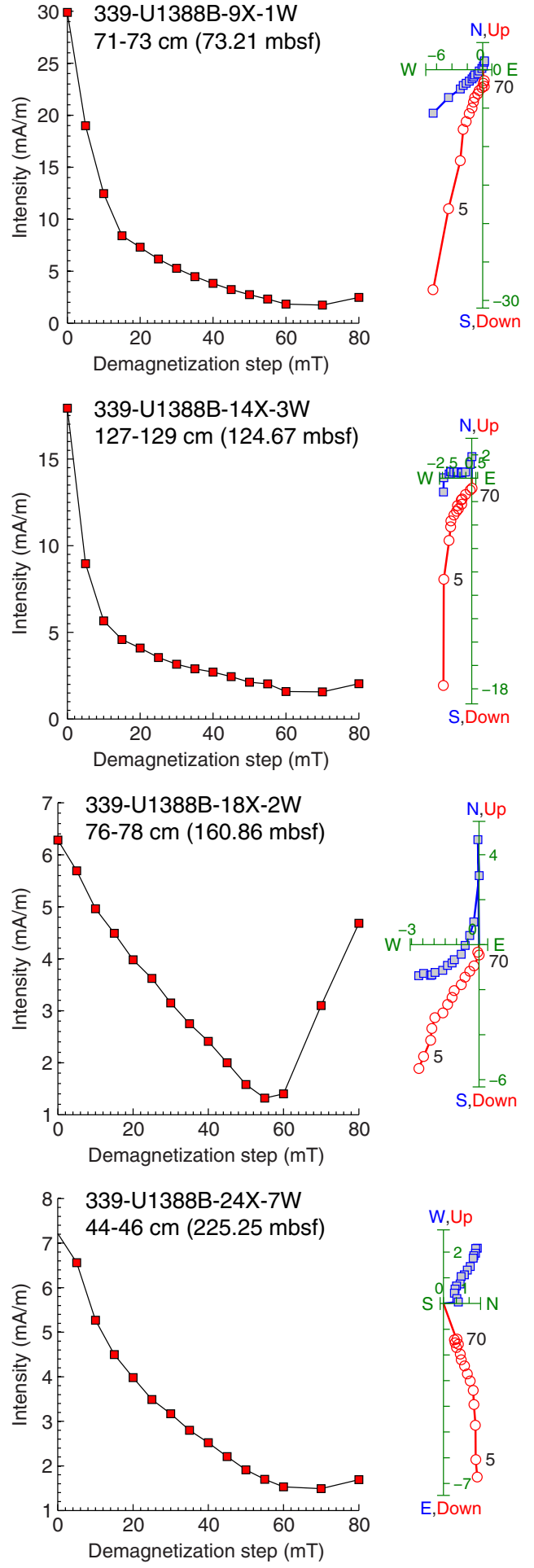
Figure F24. Plots of $P$-wave velocity (PWV) measured in Holes U1388B on the Section-Half Measurement Gantry (discrete samples) set on automatic (solid circles) and manual (open circles) mode, wet bulk density in Holes U1388B (red solid diamonds) and U1388C (open red diamonds) on discrete samples, gamma ray attenuation measured on the Whole Round Multisensor Logger (WRMSL) in Holes U1388A (black line), U1388B (gray line) and U1388C (magenta line), magnetic susceptibility (MS) measured on the WRMSL in Holes U1388A (black line), U1388B (gray line) and U1388C (magenta line), and MS obtained on split cores of Holes U1388B (green dots) and U1388C (light green dots). PP = physical properties.

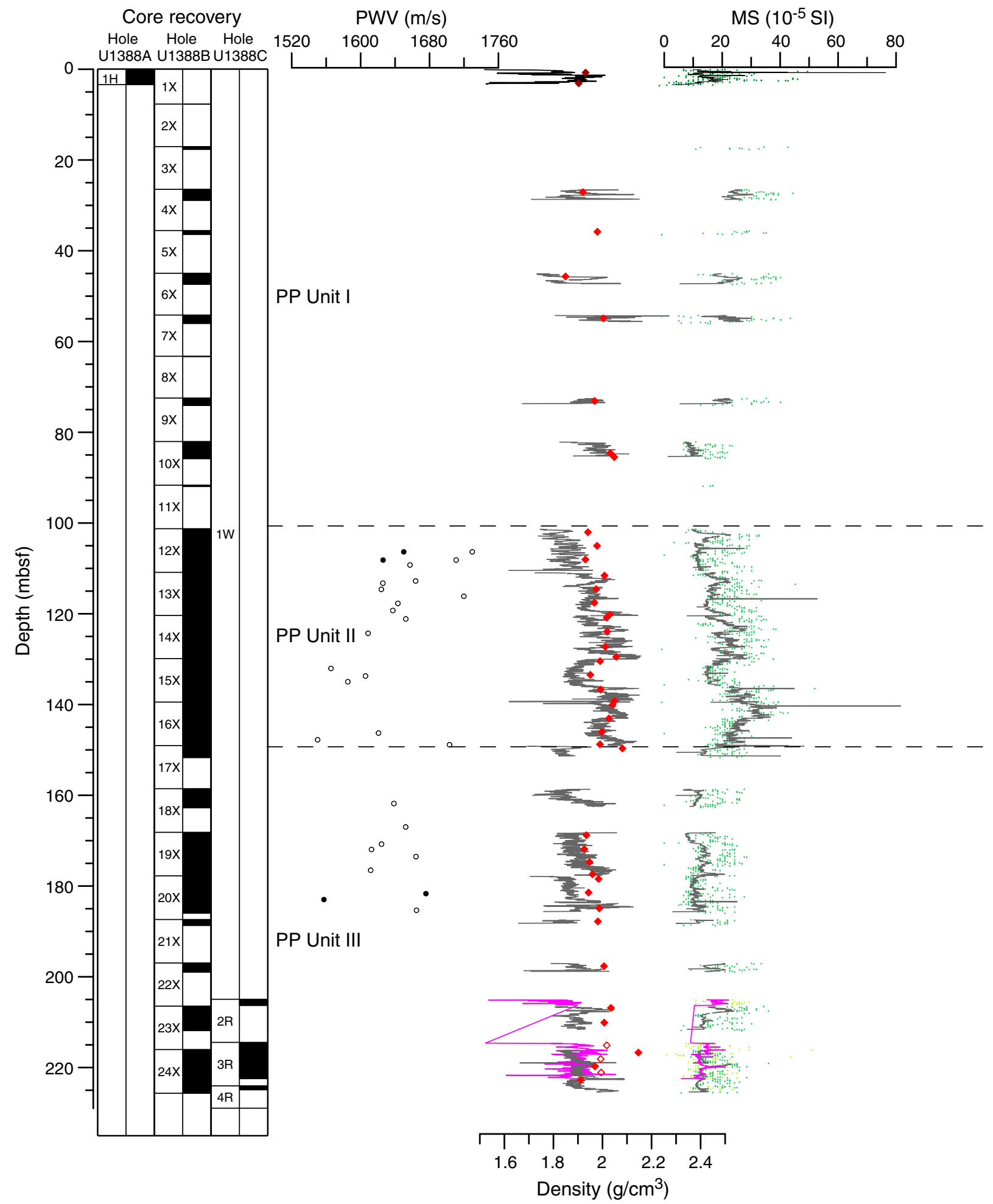


Figure F25. Plots of grain density, moisture content and porosity from discrete measurements. Solid symbols = Hole U1388A and U1388B, open symbols = U1388C. PP = physical properties.

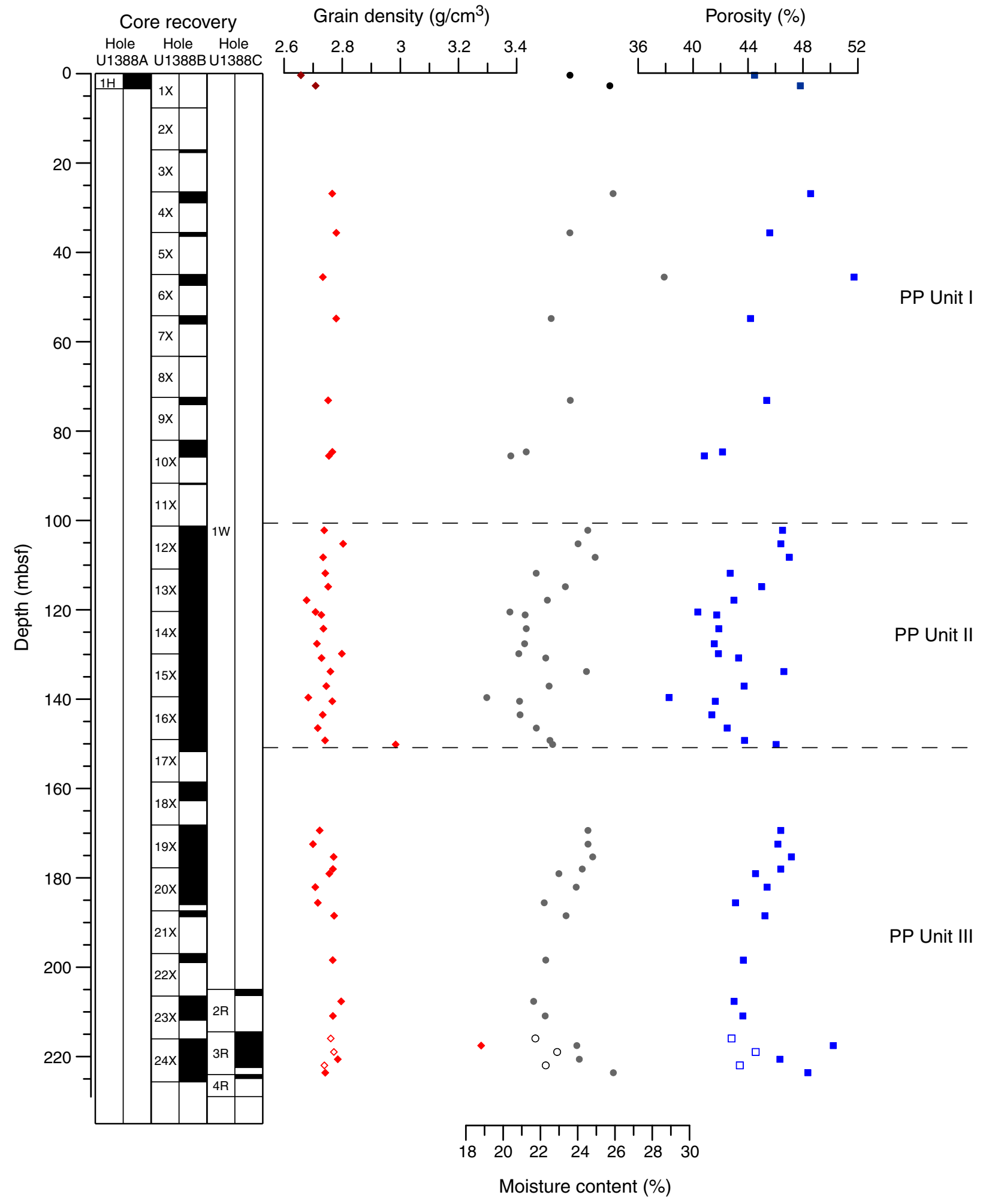


Figure F26. Plots of downhole distribution of color reflectance $\left(\mathrm{L}^{*}, \mathrm{a}^{*}\right)$ and natural gamma ray (NGR) measurements in Holes U1388A-U1388C. Heavy lines = Hole U1388A, dark lines = Hole U1388B, light lines = Hole U1388C. PP = physical properties.

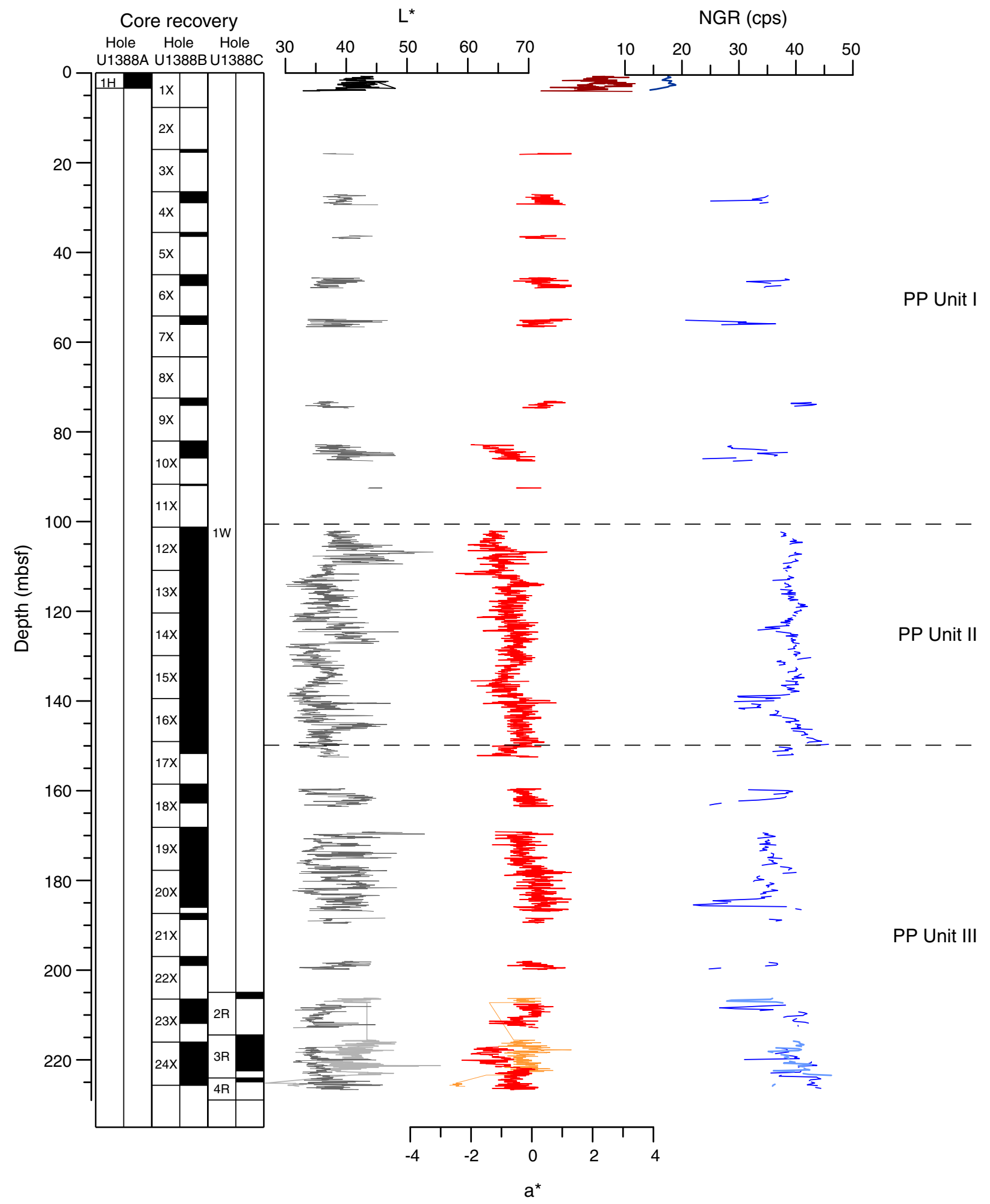


Figure F27. Plot of headspace gas analyses for volatile hydrocarbons, Site U1388.

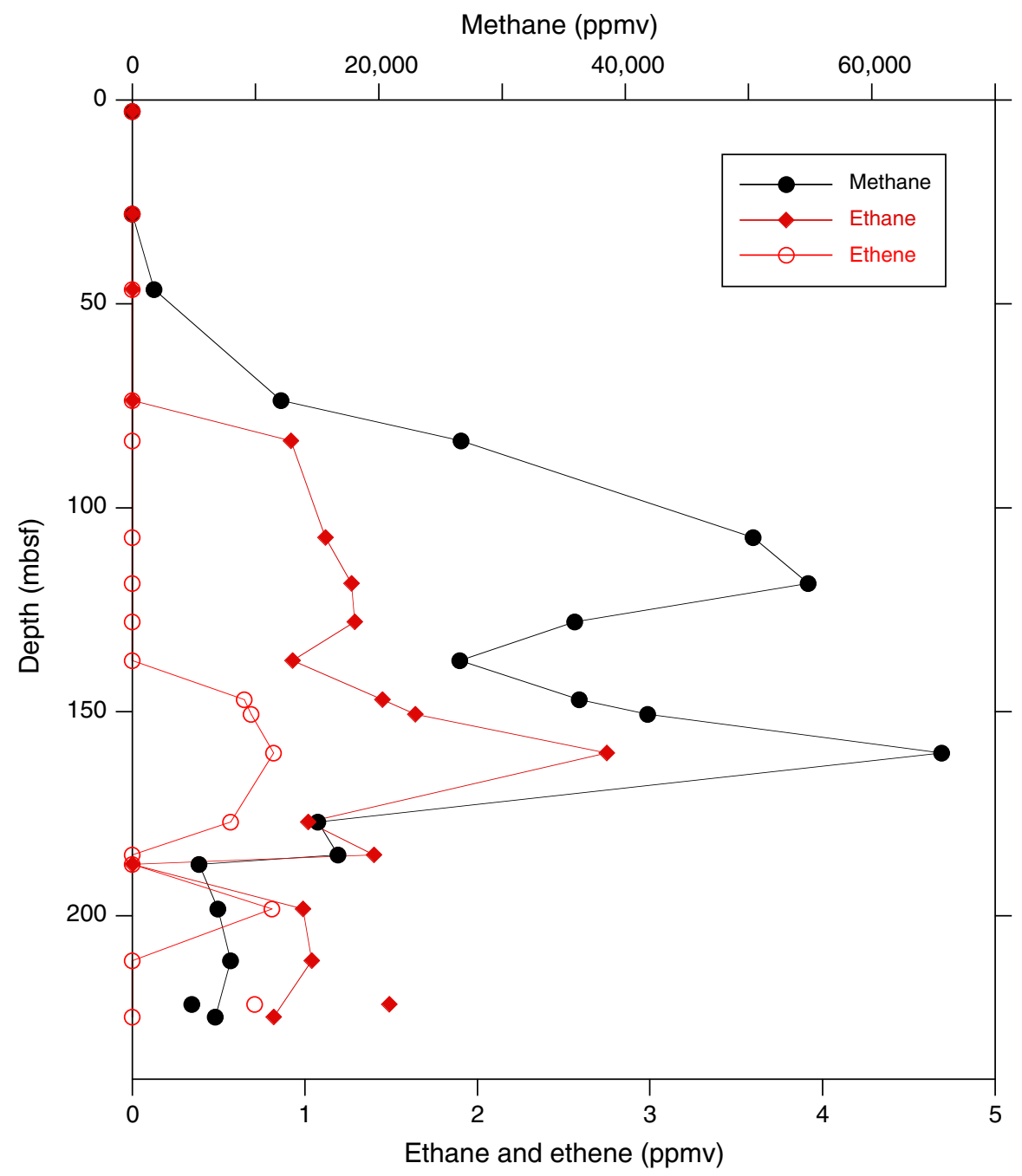


Figure F28. A-C. Plots of calculated total organic carbon (TOC), total nitrogen (TN), and C/N ratio, Holes U1388A (solid circle) and U1388B (open circles).

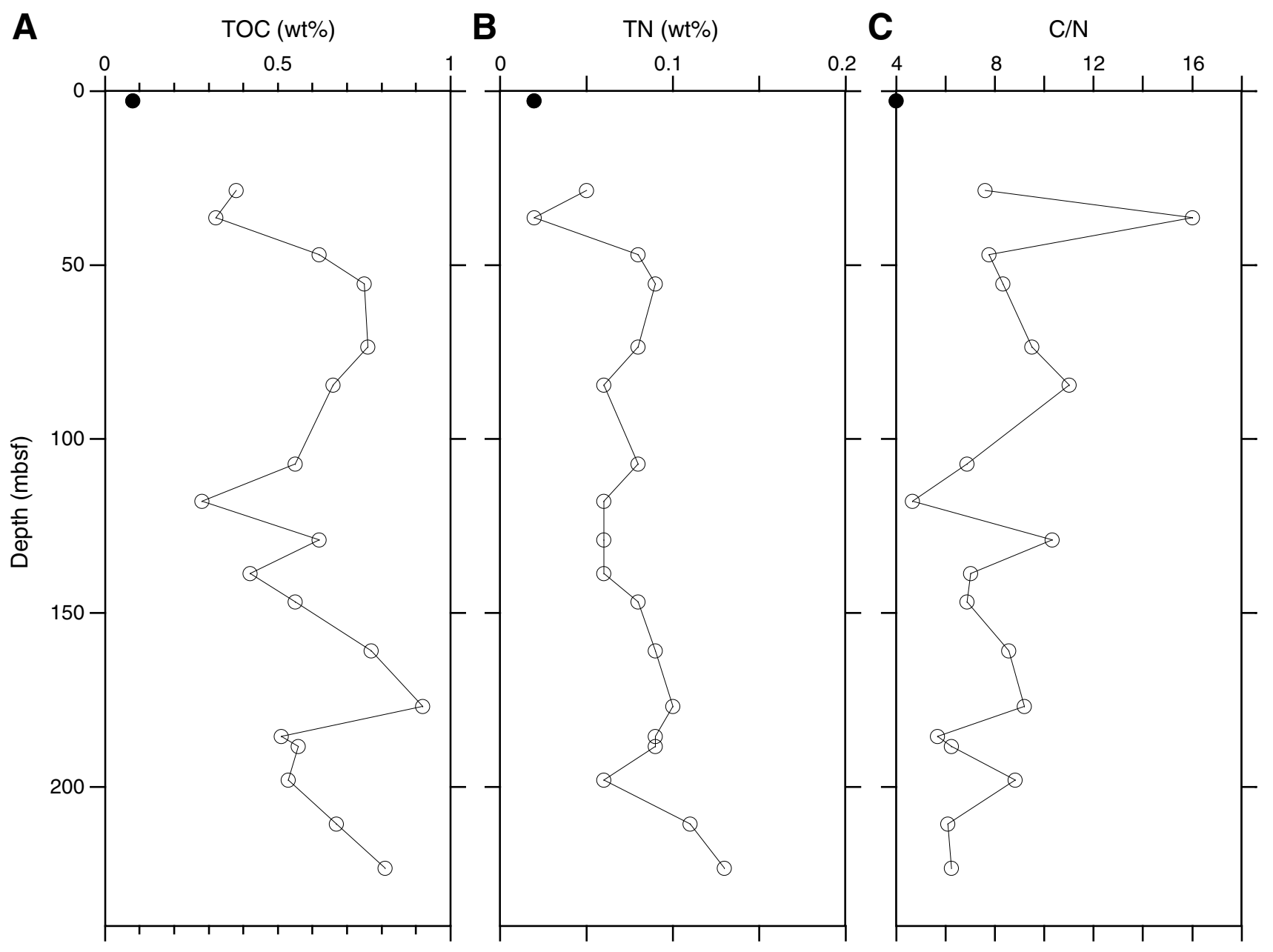


Figure F29. Plots of (A-C) interstitial water sulfate, alkalinity, ammonium, and $(D)$ hydrocarbons (open circles $=$ methane, solid circles $=$ ethene, diamonds = ethane), Hole U1385B.

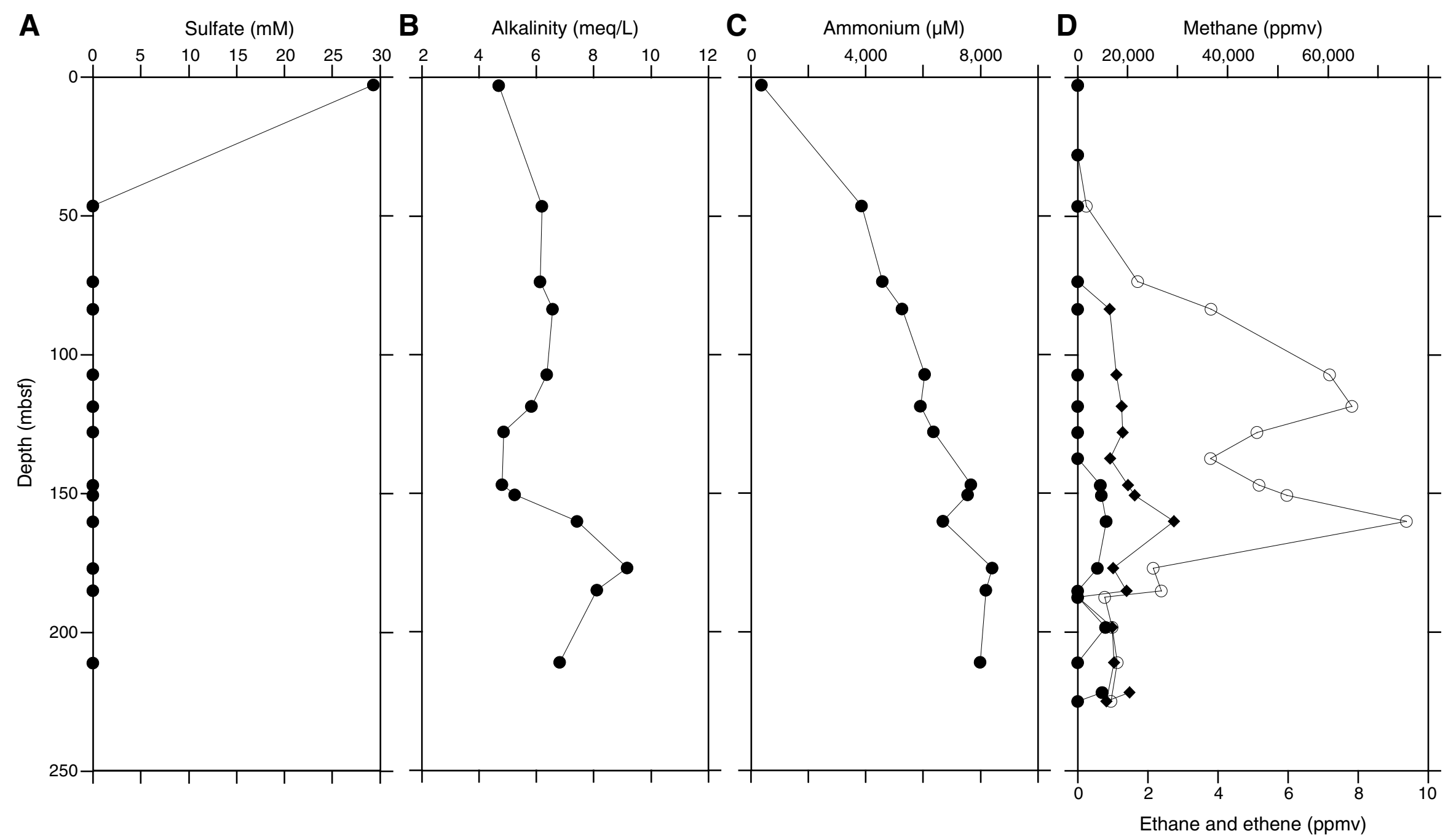


Figure F30. Plots of interstitial water calcium, magnesium, and potassium, Site U1388.

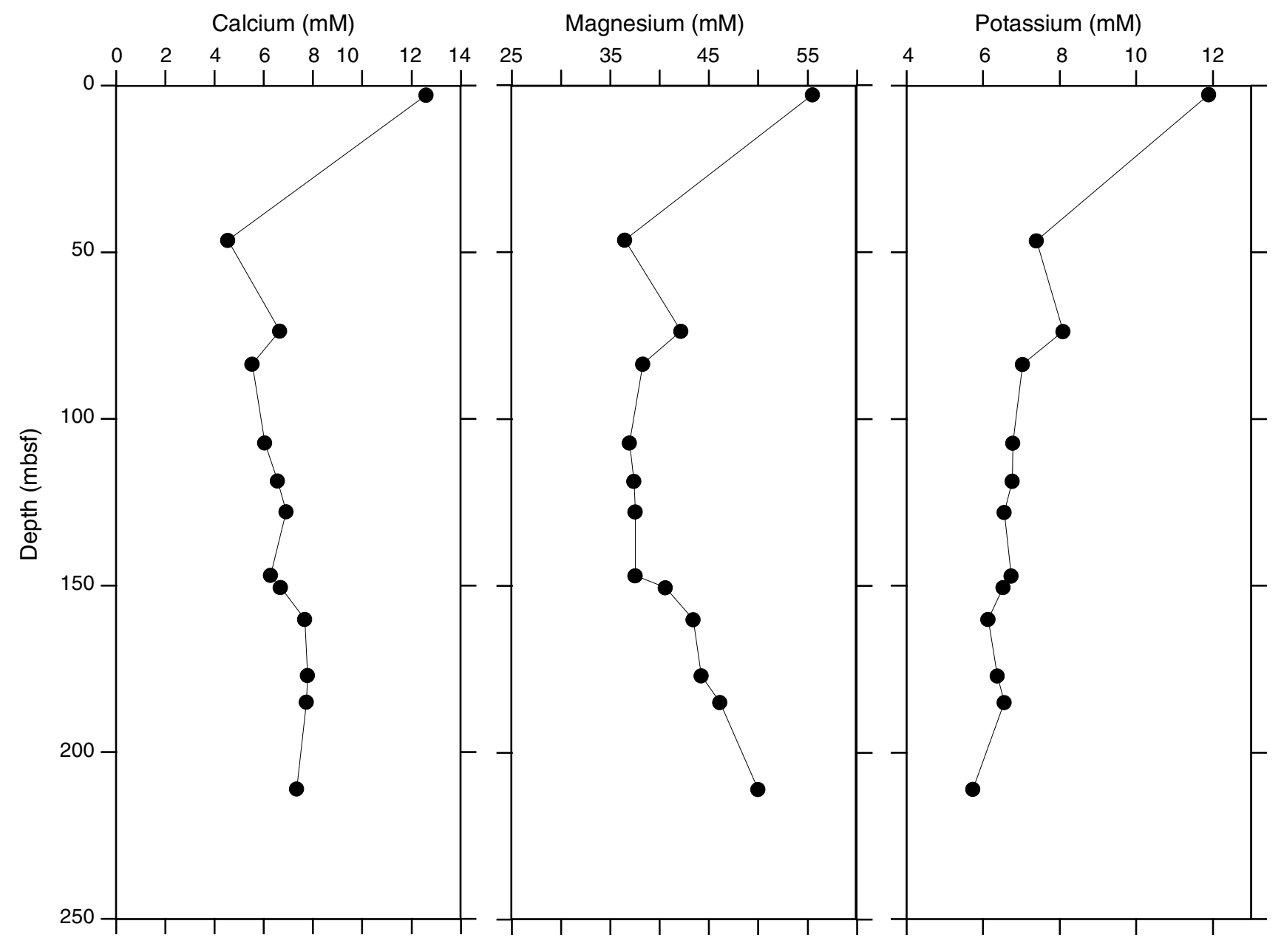


Figure F31. A-C. Plots of interstitial water sodium, chloride, and $\mathrm{Na}^{+} / \mathrm{Cl}^{-}$ratio, Site U1388. Dotted line indicates seawater $\mathrm{Na}^{+} / \mathrm{Cl}^{-}$ratio.

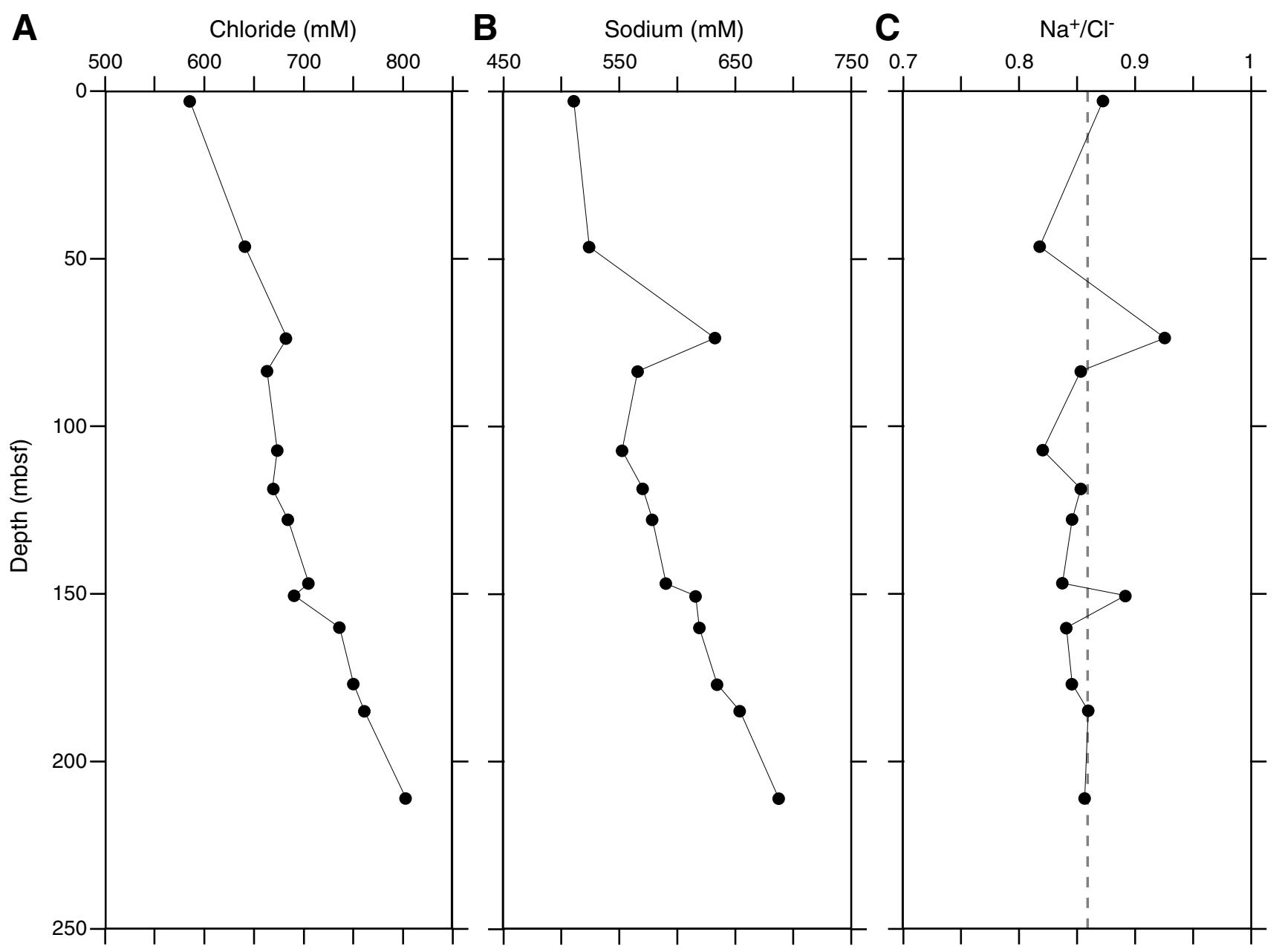




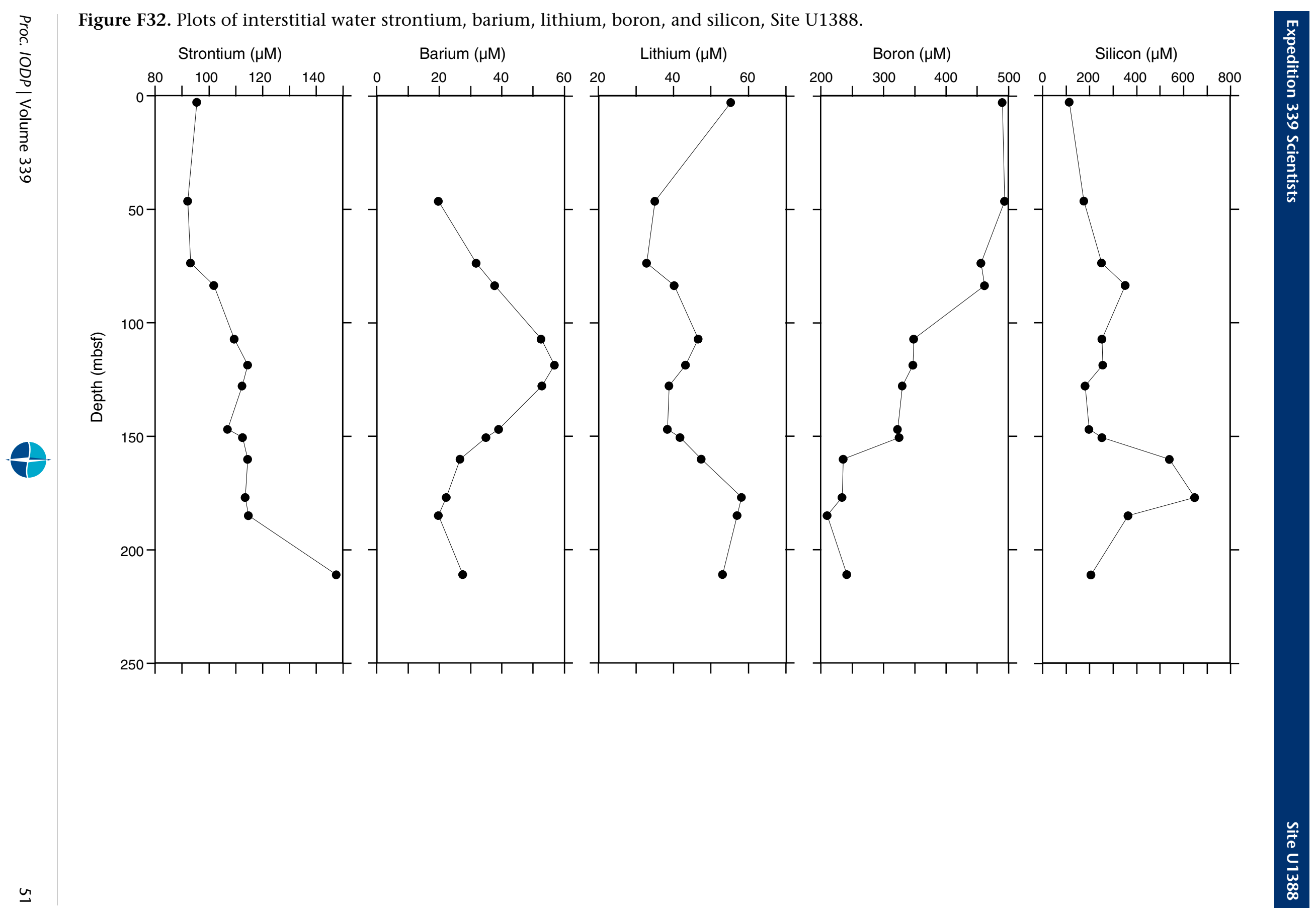


Figure F33. Plots of various elemental concentrations vs. chloride, Site U1388.
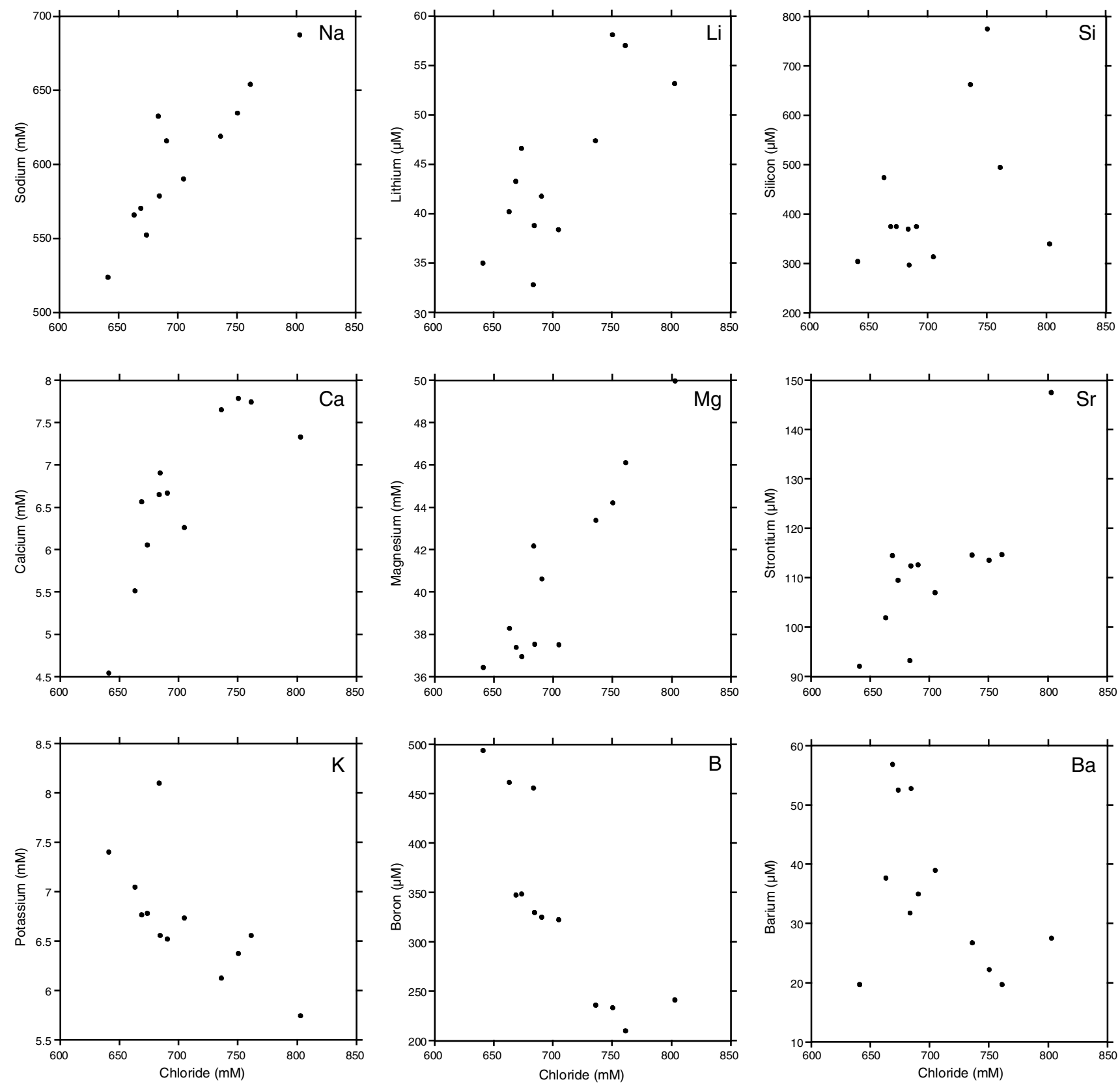
Figure F34. Plots of interstitial water stable isotopes, Site U1388. VSMOW = Vienna standard mean ocean water.

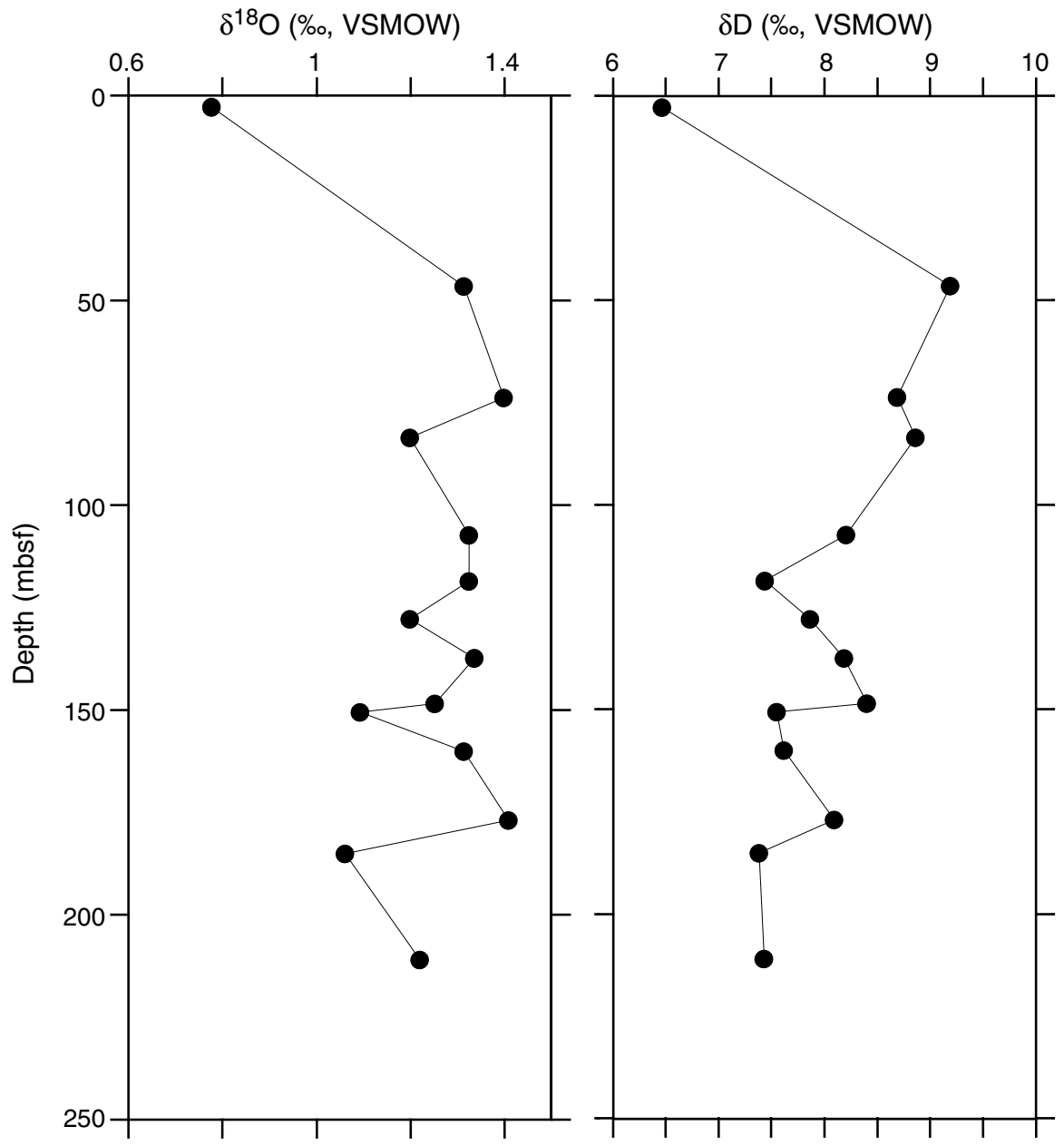


Figure F35. Plot of $\delta^{18} \mathrm{O}$ vs. $\delta \mathrm{D}$, Site U1388. VSMOW = Vienna standard mean ocean water.

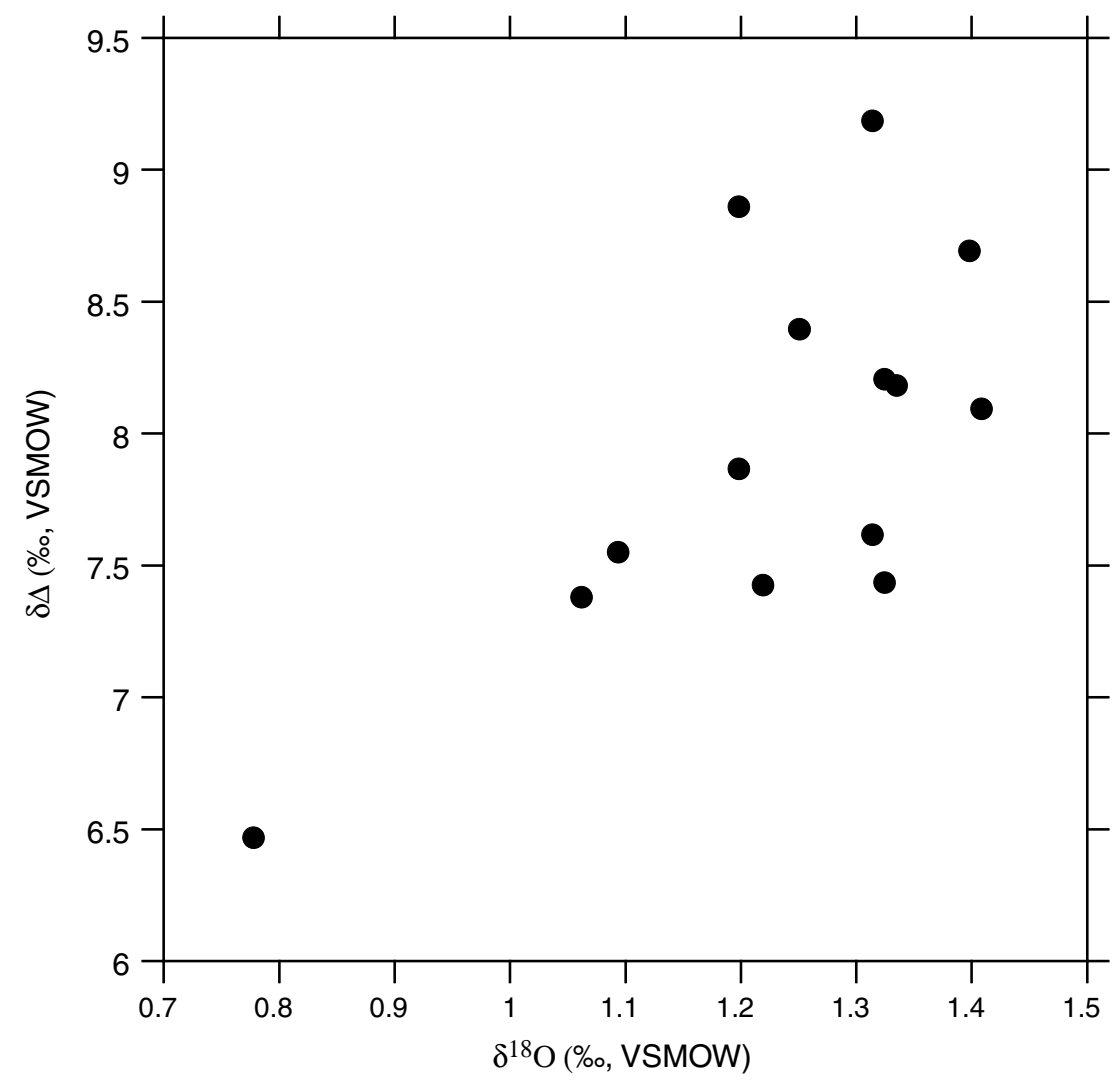


Table T1. Coring summary, Site U1388. (Continued on next page.)

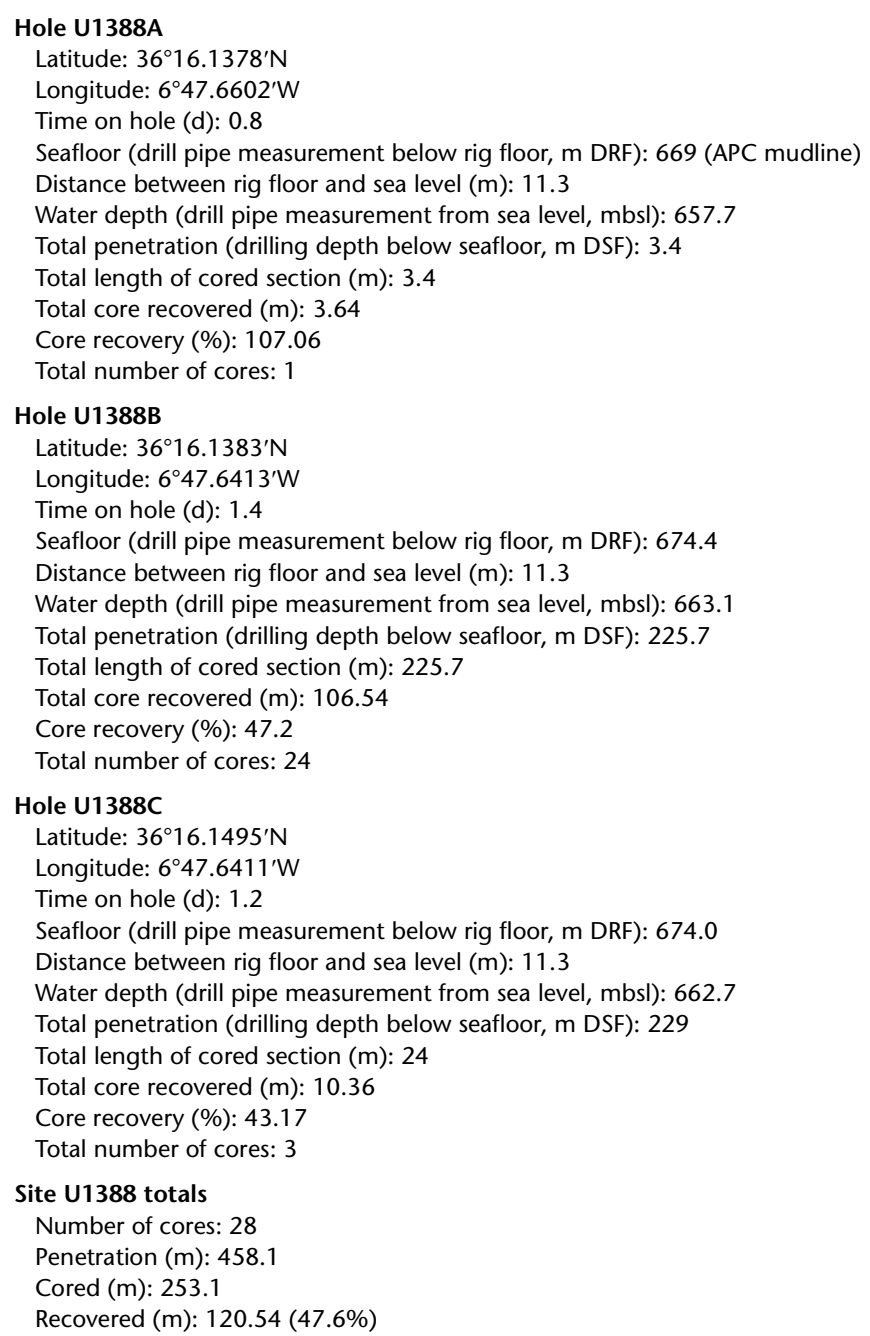

\begin{tabular}{|c|c|c|c|c|c|c|c|c|c|c|}
\hline \multirow[b]{2}{*}{ Core } & \multirow[b]{2}{*}{$\begin{array}{l}\text { Date } \\
(2011)\end{array}$} & \multirow[b]{2}{*}{$\begin{array}{l}\text { Time } \\
(h)\end{array}$} & \multicolumn{2}{|c|}{ Depth DSF (m) } & \multirow[b]{2}{*}{$\begin{array}{c}\text { Interval } \\
\text { advanced (m) }\end{array}$} & \multicolumn{2}{|c|}{ Depth CSF (m) } & \multirow[b]{2}{*}{$\begin{array}{l}\text { Length of core } \\
\text { recovered }(\mathrm{m})\end{array}$} & \multirow[b]{2}{*}{$\begin{array}{l}\text { Curated } \\
\text { length }(\mathrm{m})\end{array}$} & \multirow[b]{2}{*}{$\begin{array}{l}\text { Recovery } \\
(\%)\end{array}$} \\
\hline & & & $\begin{array}{l}\text { Top of cored } \\
\text { interval }\end{array}$ & $\begin{array}{c}\text { Bottom of } \\
\text { cored interval }\end{array}$ & & $\begin{array}{c}\text { Top of } \\
\text { recovered core }\end{array}$ & $\begin{array}{c}\text { Bottom of } \\
\text { recovered core }\end{array}$ & & & \\
\hline \multicolumn{11}{|c|}{ 339-U1388A- } \\
\hline \multirow[t]{3}{*}{$1 \mathrm{H}$} & $18 \mathrm{Dec}$ & 1510 & 0.0 & 3.4 & 3.4 & 0.0 & 3.64 & 3.64 & 3.64 & 107 \\
\hline & & & \multirow{2}{*}{\multicolumn{2}{|c|}{$\begin{array}{l}\text { Advanced total: } \\
\text { Total interval cored: }\end{array}$}} & 3.4 & & & & & \\
\hline & & & & & 3.4 & & & & & \\
\hline \multicolumn{11}{|c|}{ 339-U1388B- } \\
\hline $1 \mathrm{X}$ & $19 \mathrm{Dec}$ & 0930 & 0.0 & 7.7 & 7.7 & 0.0 & 0.00 & 0.00 & 0.00 & 0 \\
\hline $2 x$ & $19 \mathrm{Dec}$ & 1030 & 7.7 & 17.1 & 9.4 & 7.7 & 7.73 & 0.03 & 0.03 & 0 \\
\hline $3 x$ & $19 \mathrm{Dec}$ & 1135 & 17.1 & 26.5 & 9.4 & 17.1 & 17.75 & 0.65 & 0.65 & 7 \\
\hline $4 X$ & $19 \mathrm{Dec}$ & 1230 & 26.5 & 35.6 & 9.1 & 26.5 & 29.00 & 2.50 & 2.50 & 27 \\
\hline $5 X$ & $19 \mathrm{Dec}$ & 1310 & 35.6 & 45.0 & 9.4 & 35.6 & 36.50 & 0.90 & 0.90 & 10 \\
\hline $6 \mathrm{X}$ & $19 \mathrm{Dec}$ & 1345 & 45.0 & 54.2 & 9.2 & 45.0 & 47.47 & 2.47 & 2.47 & 27 \\
\hline $7 X$ & $19 \mathrm{Dec}$ & 1425 & 54.2 & 63.3 & 9.1 & 54.2 & 56.14 & 1.94 & 1.94 & 21 \\
\hline $8 X$ & $19 \mathrm{Dec}$ & 1515 & 63.3 & 72.5 & 9.2 & 63.3 & 63.40 & 0.10 & 0.10 & 1 \\
\hline $9 \mathrm{X}$ & $19 \mathrm{Dec}$ & 1605 & 72.5 & 82.1 & 9.6 & 72.5 & 74.18 & 1.68 & 1.68 & 18 \\
\hline $10 x$ & $19 \mathrm{Dec}$ & 1650 & 82.1 & 91.7 & 9.6 & 82.1 & 85.92 & 3.82 & 3.82 & 40 \\
\hline $11 x$ & $19 \mathrm{Dec}$ & 1730 & 91.7 & 101.3 & 9.6 & 91.7 & 92.06 & 0.36 & 0.36 & 4 \\
\hline $12 \mathrm{X}$ & $19 \mathrm{Dec}$ & 1815 & 101.3 & 110.9 & 9.6 & 101.3 & 110.93 & 9.63 & 9.63 & 100 \\
\hline $13 x$ & $19 \mathrm{Dec}$ & 1915 & 110.9 & 120.4 & 9.5 & 110.9 & 120.71 & 9.81 & 9.81 & 103 \\
\hline $14 X$ & $19 \mathrm{Dec}$ & 1955 & 120.4 & 129.9 & 9.5 & 120.4 & 130.19 & 9.79 & 9.79 & 103 \\
\hline $15 X$ & $19 \mathrm{Dec}$ & 2025 & 129.9 & 139.5 & 9.6 & 129.9 & 139.86 & 9.96 & 9.96 & 104 \\
\hline $16 X$ & $19 \mathrm{Dec}$ & 2100 & 139.5 & 149.1 & 9.6 & 139.5 & 149.32 & 9.82 & 9.82 & 102 \\
\hline $17 X$ & $19 \mathrm{Dec}$ & 2140 & 149.1 & 158.6 & 9.5 & 149.1 & 151.79 & 2.69 & 2.69 & 28 \\
\hline $18 X$ & $19 \mathrm{Dec}$ & 2240 & 158.6 & 168.2 & 9.6 & 158.6 & 162.82 & 4.22 & 4.22 & 44 \\
\hline
\end{tabular}


Table T1 (continued).

\begin{tabular}{|c|c|c|c|c|c|c|c|c|c|c|}
\hline \multirow[b]{2}{*}{ Core } & \multirow[b]{2}{*}{$\begin{array}{l}\text { Date } \\
(2011)\end{array}$} & \multirow[b]{2}{*}{$\begin{array}{l}\text { Time } \\
\text { (h) }\end{array}$} & \multicolumn{2}{|c|}{ Depth DSF (m) } & \multirow[b]{2}{*}{$\begin{array}{c}\text { Interval } \\
\text { advanced (m) }\end{array}$} & \multicolumn{2}{|c|}{ Depth CSF (m) } & \multirow[b]{2}{*}{$\begin{array}{l}\text { Length of core } \\
\text { recovered }(\mathrm{m})\end{array}$} & \multirow[b]{2}{*}{$\begin{array}{l}\text { Curated } \\
\text { length }(\mathrm{m})\end{array}$} & \multirow[b]{2}{*}{$\begin{array}{c}\text { Recovery } \\
\text { (\%) }\end{array}$} \\
\hline & & & $\begin{array}{c}\text { Top of cored } \\
\text { interval }\end{array}$ & $\begin{array}{l}\text { Bottom of } \\
\text { cored interval }\end{array}$ & & $\begin{array}{c}\text { Top of } \\
\text { recovered core }\end{array}$ & $\begin{array}{l}\text { Bottom of } \\
\text { recovered core }\end{array}$ & & & \\
\hline $19 x$ & $20 \mathrm{Dec}$ & 0005 & 168.2 & 177.8 & 9.6 & 168.2 & 178.02 & 9.82 & 9.82 & 102 \\
\hline $20 x$ & $20 \mathrm{Dec}$ & 0110 & 177.8 & 187.4 & 9.6 & 177.8 & 186.08 & 8.28 & 8.28 & 86 \\
\hline $21 x$ & $20 \mathrm{Dec}$ & 0225 & 187.4 & 197.0 & 9.6 & 187.4 & 188.80 & 1.40 & 1.40 & 15 \\
\hline $22 X$ & $20 \mathrm{Dec}$ & 0335 & 197.0 & 206.5 & 9.5 & 197.0 & 199.04 & 2.04 & 2.04 & 21 \\
\hline $23 x$ & $20 \mathrm{Dec}$ & 0530 & 206.5 & 216.1 & 9.6 & 206.5 & 211.96 & 5.46 & 5.46 & 57 \\
\hline \multirow[t]{3}{*}{$24 X$} & $20 \mathrm{Dec}$ & 0645 & 216.1 & 225.7 & 9.6 & 216.1 & 225.73 & 9.63 & 9.63 & 100 \\
\hline & & & & Advanced total: & 225.7 & & & & & \\
\hline & & & Total & I interval cored: & 225.7 & & & & & \\
\hline \multicolumn{11}{|c|}{ 339-U1388C- } \\
\hline $1 \mathrm{~W}$ & $21 \mathrm{Dec}$ & 0600 & & & $* * * *$ Drilled & from 0 to 205.0 & 0 m DSF withou & t coring ${ }^{\star \star \star \star}$ & & \\
\hline $2 \mathrm{R}$ & $21 \mathrm{Dec}$ & 0715 & 205.0 & 214.5 & 9.5 & 205.0 & 206.43 & 1.43 & 1.43 & 15 \\
\hline $3 R$ & $21 \mathrm{Dec}$ & 0835 & 214.5 & 224.1 & 9.6 & 214.5 & 222.55 & 8.05 & 8.05 & 84 \\
\hline \multirow[t]{3}{*}{$4 \mathrm{R}$} & $21 \mathrm{Dec}$ & 1355 & 224.1 & 229.0 & 4.9 & 224.1 & 224.98 & 0.88 & 0.88 & 18 \\
\hline & & & & Advanced total: & 229.0 & & & & & \\
\hline & & & Total & I interval cored: & 24.0 & & & & & \\
\hline
\end{tabular}

$\mathrm{DRF}=$ drilling depth below rig floor, $\mathrm{DSF}=$ drilling depth below seafloor, $\mathrm{CSF}=$ core depth below seafloor. $\mathrm{H}=$ advanced piston coring system, $\mathrm{X}$ = extended core barrel system, $\mathrm{R}=$ rotary core barrel system, $\mathrm{W}=$ washed interval. Time is Universal Time Coordinated. 
Table T2. Sediment textures, compositions, and lithology names determined by smear slide, Site U1388.

\begin{tabular}{|c|c|c|c|c|c|c|c|c|c|}
\hline & \multicolumn{3}{|c|}{ Texture (\%) } & \multicolumn{4}{|c|}{ Composition (\%) } & \multirow[b]{2}{*}{ Comments } & \multirow[b]{2}{*}{ Also reported } \\
\hline & Sand & Silt & Clay & Siliciclastic & $\begin{array}{c}\text { Detrital } \\
\text { carbonate }\end{array}$ & $\begin{array}{l}\text { Biogenic } \\
\text { carbonate }\end{array}$ & $\begin{array}{l}\text { Biogenic } \\
\text { silica }\end{array}$ & & \\
\hline $\begin{array}{l}\text { Sand (with biogenic } \\
\text { carbonate) }\end{array}$ & $75-95$ & $1-15$ & $0-10$ & $60-95$ & $2-30$ & $0-30$ & $0-2$ & $\begin{array}{l}\text { Subangular to well rounded quartz, felspars, mica, rock } \\
\text { fragments, zircon, opaques, heavy minerals, glauconite, } \\
\text { foraminifers, and sometimes many pyrite nodules }\end{array}$ & \\
\hline $\begin{array}{l}\text { Silty sand with biogenic } \\
\text { carbonate (calcareous } \\
\text { silty sand) }\end{array}$ & $40-70$ & $20-40$ & $10-20$ & $30-60$ & $30-50$ & $5-20$ & $0-2$ & $\begin{array}{l}\text { Quartz, opaques, feldspars, mica, zircon, detrital dolomite, } \\
\text { hornblende, glauconite, nannofossils, foraminifers, and } \\
\text { calcareous and sponge spicules }\end{array}$ & \\
\hline $\begin{array}{l}\text { Sandy silt with biogenic } \\
\text { carbonate (calcareous } \\
\text { sandy silt) }\end{array}$ & $20-40$ & $45-60$ & $15-20$ & $45-60$ & $20-35$ & 20 & $0-4$ & $\begin{array}{l}\text { Quartz, mica, opaques, feldspars, glauconite, pyrite, detrital and } \\
\text { authigenic dolomite, nannofossils, foraminifers, and sponge } \\
\text { and calcareous spicules }\end{array}$ & \\
\hline $\begin{array}{l}\text { Silty mud with biogenic } \\
\text { carbonate (calcareous } \\
\text { silty mud) }\end{array}$ & $5-20$ & $35-70$ & $30-40$ & $25-50$ & $25-55$ & $20-35$ & $0-4$ & $\begin{array}{l}\text { Opaques, mica, feldspars, heavy minerals, zircon, glauconite, } \\
\text { detrital and authigenic dolomite, pyrite, nannofossils, } \\
\text { foraminifers, and calcareous and sponge spicules }\end{array}$ & $\begin{array}{l}\text { U1388C-3R-2, } 25 \mathrm{~cm} ; \\
\text { diatoms and radiolarians }\end{array}$ \\
\hline $\begin{array}{l}\text { Mud with biogenic } \\
\text { carbonate }\end{array}$ & $0-10$ & $20-40$ & $55-80$ & $20-60$ & $25-55$ & $15-25$ & $0-2$ & $\begin{array}{l}\text { Mica, zircon, glauconite, opaques, heavy minerals, detrital and } \\
\text { authigenic dolomite, nannofossils, and sponge spicule } \\
\text { fragments }\end{array}$ & $\begin{array}{l}\text { U1388B-19X-1, } 9 \mathrm{~cm} ; \\
\text { diatom and radiolarian } \\
\text { fragments }\end{array}$ \\
\hline $\begin{array}{l}\text { Nannofossil mud (mud } \\
\text { with nannofossils) }\end{array}$ & $0-5$ & $20-30$ & $70-80$ & $35-55$ & $30-40$ & $15-25$ & & Pyrite, nannofossils, and calcareous and sponge spicules & $\begin{array}{l}\text { U1388B-24X-5, } 138 \mathrm{~cm} ; \\
\text { wood fragments }\end{array}$ \\
\hline
\end{tabular}

Table T3. XRD peak intensities of minerals from bulk sediment, Site U1388.

\begin{tabular}{|c|c|c|c|c|c|c|c|c|c|c|c|c|c|c|c|}
\hline $\begin{array}{l}\text { Core, section, } \\
\text { interval (cm) }\end{array}$ & $\begin{array}{l}\text { Depth } \\
\text { (mbsf) }\end{array}$ & $\begin{array}{c}\text { Total } \\
\text { intensity } \\
\text { (counts) }\end{array}$ & $\begin{array}{c}\text { Quartz } \\
\text { (counts) }\end{array}$ & $\begin{array}{l}\text { Calcite } \\
\text { (counts) }\end{array}$ & $\begin{array}{l}\text { K-feldspar } \\
\text { (counts) }\end{array}$ & $\begin{array}{l}\text { Plagioclase } \\
\text { (counts) }\end{array}$ & $\begin{array}{l}\text { Dolomite } \\
\text { (counts) }\end{array}$ & $\begin{array}{l}\text { Chlorite } \\
\text { (counts) }\end{array}$ & $\begin{array}{l}\text { Kaolinite } \\
\text { (counts) }\end{array}$ & $\begin{array}{c}\text { Illite } \\
\text { (counts) }\end{array}$ & $\begin{array}{l}\text { Smectite } \\
\text { (counts) }\end{array}$ & $\begin{array}{l}\text { Hornblende } \\
\text { (counts) }\end{array}$ & $\begin{array}{c}\text { Augite } \\
\text { (counts) }\end{array}$ & $\begin{array}{c}\text { Pyrite } \\
\text { (counts) }\end{array}$ & $\begin{array}{r}\text { Aragonite } \\
\text { (counts) }\end{array}$ \\
\hline \multicolumn{16}{|l|}{339} \\
\hline U1388A-1H-2, 115-116 & 2.65 & 162,621 & 107,577 & 14,225 & 13,229 & 10,773 & 8,893 & NA & 659 & 3,421 & 67 & 656 & NA & NA & 3,121 \\
\hline U1388B-4X-2, 50-51 & 28.50 & 60,738 & 34,942 & 13,870 & 481 & 1,295 & 3,003 & 648 & 1,581 & 3,588 & 450 & 201 & NA & 679 & NA \\
\hline U1388B-5X-CC, 31-32 & 36.34 & 172,681 & 70,098 & 14,409 & 6,889 & 14,939 & 53,594 & 983 & 1,866 & 9,311 & 301 & 291 & NA & NA & NA \\
\hline U1388B-6X-2, 48-49 & 46.98 & 47,298 & 26,081 & 10,078 & 595 & 1,235 & 1,093 & 1,018 & 2,386 & 3,751 & 988 & 73 & NA & NA & NA \\
\hline U1388B-7X-1, 114-115 & 55.34 & 47,548 & 29,517 & 9,609 & 420 & 1,185 & 2,037 & 438 & 1,216 & 2,246 & 547 & 119 & NA & 214 & NA \\
\hline U1388B-10X-2, 97-99 & 84.57 & 55,753 & 28,088 & 13,358 & 713 & 1,713 & 4,153 & 932 & 1,927 & 4,113 & 689 & 67 & NA & NA & NA \\
\hline U1388B-12X-4, 131-132 & 107.11 & 44,351 & 22,159 & 13,375 & 395 & 1,102 & 1,242 & 581 & 1,666 & 2,759 & 696 & NA & 376 & NA & NA \\
\hline U1388B-13X-6, 87-88 & 117.93 & 57,381 & 31,184 & 14,545 & 906 & 1,479 & 2,737 & 744 & 1,978 & 3,184 & 624 & NA & NA & NA & NA \\
\hline U1388B-14X-6, 116-117 & 129.06 & 63,775 & 36,715 & 13,630 & 1,080 & 1,733 & 3,946 & 746 & 2,209 & 3,060 & 482 & 174 & NA & NA & NA \\
\hline U1388B-15X-6, 130-131 & 138.70 & 66,468 & 40,042 & 12,945 & NA & 2,413 & 1,626 & 593 & 1,919 & 2,194 & 482 & NA & 4,254 & NA & NA \\
\hline U1388B-16X-5, 133-134 & 146.83 & 62,547 & 39,546 & 11,639 & 572 & 2,045 & 1,824 & 819 & 2,058 & 2,997 & 479 & 92 & NA & NA & 476 \\
\hline U1388B-18X-2, 80-81 & 160.90 & 50,070 & 26,442 & 11,531 & 497 & 2,745 & 1,805 & 725 & 1,790 & 3,218 & 675 & 112 & NA & NA & 530 \\
\hline U1388B-19X-6, 119-120 & 176.89 & 47,769 & 25,491 & 13,855 & NA & 1,370 & 1,393 & 638 & 1,315 & 1,941 & 529 & 74 & NA & 548 & 614 \\
\hline U1388B-20X-6, 50-51 & 185.57 & 47,595 & 29,914 & 10,612 & 494 & 820 & 796 & 636 & 1,507 & 1,670 & 844 & 155 & NA & 147 & NA \\
\hline U1388B-21X-CC, 12-13 & 188.37 & 46,139 & 28,106 & 10,697 & 447 & 1,128 & 1,061 & 644 & 1,301 & 1,622 & 790 & NA & NA & NA & 343 \\
\hline U1388B-22X-1, 106-107 & 198.06 & 71,266 & 39,446 & 15,555 & 1,322 & 1,826 & 4,624 & 869 & 2,342 & 3,011 & 312 & 82 & 949 & NA & 928 \\
\hline U1388B-23X-3, 125-126 & 210.75 & 44,635 & 25,426 & 11,327 & 481 & 1,220 & 877 & 664 & 1,452 & 2,234 & 646 & 22 & NA & 286 & NA \\
\hline U1388C-3R-4, 114-115 & 220.14 & 46,061 & 26,678 & 11,176 & 407 & 1,111 & 998 & 747 & 1,708 & 2,248 & 538 & NA & 450 & NA & NA \\
\hline U1388B-24X-5, 131-132 & 223.41 & 41,169 & 22,490 & 10,871 & 447 & 824 & 848 & 688 & 1,650 & 2,318 & 583 & NA & 406 & NA & NA \\
\hline U1388C-4R-1, 64-65 & 224.74 & 41,585 & 24,522 & 10,357 & 565 & 863 & 796 & 623 & 1,388 & 1,691 & 494 & NA & NA & 286 & NA \\
\hline
\end{tabular}


Table T4. Biostratigraphic datums, Hole U1388B.

\begin{tabular}{|c|c|c|c|c|c|}
\hline \multirow[b]{2}{*}{ Event } & \multirow[b]{2}{*}{ Reference } & \multirow{2}{*}{$\begin{array}{c}\text { Age } \\
\text { (Ma) }\end{array}$} & \multicolumn{3}{|c|}{ Depth (mbsf) } \\
\hline & & & Top & Bottom & Mean \\
\hline FO Emiliania huxleyi & Raffi et al., 2006 & 0.26 & 47.47 & 56.14 & 51.81 \\
\hline LO Pseudoemiliania lacunosa & Raffi et al., 2006 & 0.46 & 162.82 & 178.02 & 170.42 \\
\hline
\end{tabular}

$F O=$ first occurrence, $L O=$ last occurrence.

Table T5. Abundance of nannofossils, Site U1388.

\begin{tabular}{|c|c|c|c|c|c|c|c|c|c|c|c|c|c|c|c|c|c|c|c|c|c|c|}
\hline $\begin{array}{l}\text { Core, section, } \\
\text { interval }(\mathrm{cm})\end{array}$ & $\begin{array}{l}\text { Depth } \\
\text { (mbsf) }\end{array}$ & 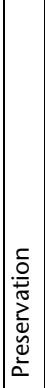 & 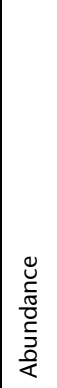 & 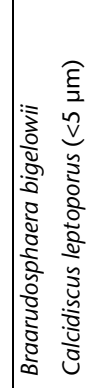 & 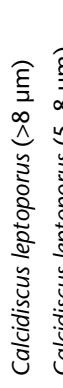 & 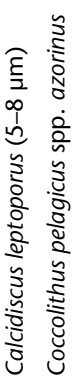 & 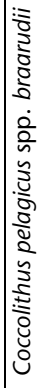 & 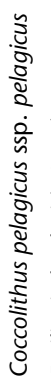 & 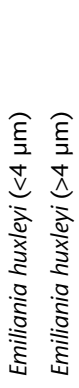 & 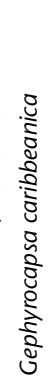 & 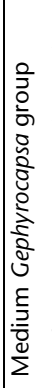 & 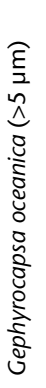 & 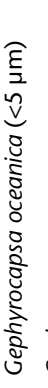 & 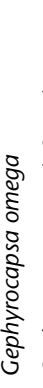 & 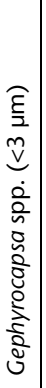 & 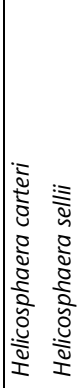 & 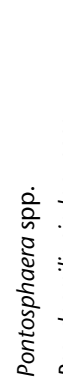 & 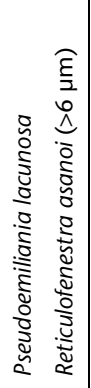 & 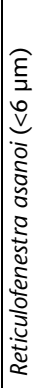 & 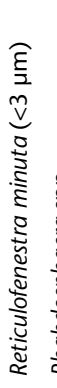 & 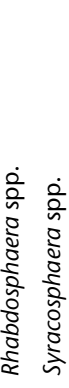 & 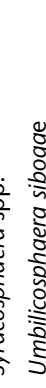 \\
\hline $\begin{array}{l}\text { 339-U1388A- } \\
1 \mathrm{H}-\mathrm{CC}\end{array}$ & 3.64 & M & $\mathrm{R}$ & & & $\mathrm{R}$ & $\mathrm{R}$ & $P$ & $\mathrm{~F}$ & & & $\mathrm{P}$ & $\mathrm{R}$ & & & $\mathrm{R}$ & & & & & & $\mathrm{R}$ \\
\hline $\begin{array}{l}\text { 339-U1388B- } \\
2 \mathrm{X}-\mathrm{CC}\end{array}$ & 7.73 & $M$ & A & $P$ & $\mathrm{~F}$ & $\mathrm{~F}$ & $\mathrm{~F}$ & $\mathrm{~F}$ & & $\mathrm{R}$ & C & & & & $\mathrm{D}$ & $\mathrm{F} \quad \mathrm{F}$ & & C & & D & & \\
\hline $3 X-C C$ & 17.73 & $M$ & C & & & $\mathrm{R}$ & $\mathrm{R}$ & $\mathrm{R}$ & C & & & $\mathrm{R}$ & $\mathrm{R}$ & & $C$ & $\mathrm{R}$ & & & & & & $\mathrm{R}$ \\
\hline $4 \mathrm{X}-\mathrm{CC}$ & 29.00 & $M$ & C & & & $\mathrm{R}$ & & $\mathrm{R}$ & & & & & & & $\mathrm{R}$ & $\mathrm{R}$ & & & & & & \\
\hline $5 X-C C$ & 36.50 & $M$ & $\mathrm{R}$ & & & $\mathrm{R}$ & & & $P$ & & & & & & $\mathrm{R}$ & & & & & & & \\
\hline $6 \mathrm{X}-\mathrm{CC}$ & 47.47 & $P$ & $P$ & & & & & & $P$ & & & & & & $\mathrm{P}$ & & & & & & & \\
\hline $7 \mathrm{X}-\mathrm{CC}$ & 56.14 & $M$ & $\mathrm{~F}$ & & & $\mathrm{P}$ & & & & & & & $P$ & & $\mathrm{P}$ & & & & & & & \\
\hline $8 \mathrm{X}-\mathrm{CC}$ & 63.40 & $M$ & A & & & $\mathrm{R}$ & & $\mathrm{R}$ & & & & $\mathrm{R}$ & & & $\mathrm{D}$ & $\mathrm{R}$ & & & & A & $\mathrm{R}$ & R \\
\hline 9X-CC & 74.18 & & B & & & & & & & & & & & & & & & & & & & \\
\hline 10X-CC & 85.92 & $M$ & A & & & & & & & & & & C & & $\mathrm{A}$ & $\mathrm{F}$ & & & & A & & \\
\hline $11 X-1,5$ & 91.75 & $M$ & A & & & $\mathrm{F}$ & $\mathrm{F}$ & $\mathrm{F}$ & & $\mathrm{F}$ & C & & $\mathrm{F}$ & & C & $\mathrm{F}$ & & & & C & & \\
\hline $12 \mathrm{X}-\mathrm{CC}$ & 110.93 & G & A & & & & & & & $\mathrm{F}$ & C & & & & $\mathrm{D}$ & $\mathrm{F}$ & $\mathrm{F}$ & & & D & $\mathrm{F}$ & $=$ \\
\hline $13 \mathrm{X}-\mathrm{CC}$ & 120.71 & $M$ & VA & & & & $\mathrm{F}$ & $\mathrm{F}$ & & & & & C & & C & $\mathrm{F}$ & & & & C & & \\
\hline $14 \mathrm{X}-\mathrm{CC}$ & 130.19 & G & A & & & & & $\mathrm{R}$ & & & & & C & & $\mathrm{A}$ & & & & & A & $\mathrm{F}$ & $=F$ \\
\hline $15 X-C C$ & 139.86 & G & A & & & $\mathrm{R}$ & $\mathrm{R}$ & $\mathrm{R}$ & & $\mathrm{F}$ & & & C & & $\mathrm{A}$ & $\mathrm{R}$ & & & & A & $\mathrm{R} \quad \mathrm{F}$ & F \\
\hline $16 \mathrm{X}-\mathrm{CC}$ & 149.32 & G & VA & & & & $\mathrm{R}$ & & & $\mathrm{F}$ & & & $\mathrm{F}$ & & A & & & & & A & $\mathrm{R}$ & 2 \\
\hline $17 X-C C$ & 151.79 & $M$ & VA & & & $\mathrm{R}$ & $\mathrm{R}$ & $\mathrm{R}$ & & C & & & C & & $\mathrm{A}$ & & & & & A & $\mathrm{F}$ & F \\
\hline $18 \mathrm{X}-\mathrm{CC}$ & 162.82 & $M$ & C & & & $\mathrm{R}$ & & $\mathrm{R}$ & & $\mathrm{R}$ & & & $\mathrm{R}$ & & $\mathrm{F}$ & & & & & $\mathrm{F}$ & & \\
\hline 19X-CC & 178.02 & $M$ & VA & & & $P$ & $\mathrm{R}$ & $\mathrm{R}$ & & A & & $\mathrm{R}$ & $\mathrm{F}$ & & $\mathrm{D}$ & $\mathrm{R}$ & $\mathrm{R}$ & $\mathrm{F}$ & & $\mathrm{F}$ & $\mathrm{F}$ & $=$ \\
\hline 20X-CC & 185.91 & $M$ & A & & & $\mathrm{R}$ & $\mathrm{F}$ & $\mathrm{F}$ & & C & $\mathrm{F}$ & & C & & $\mathrm{A}$ & $\mathrm{R}$ & $\mathrm{R}$ & $\mathrm{R}$ & & $\mathrm{F}$ & $\mathrm{R}$ & $R$ \\
\hline $21 \mathrm{X}-\mathrm{CC}$ & 188.66 & $M$ & $\mathrm{~F}$ & & & & & & & $\mathrm{R}$ & $\mathrm{R}$ & & $\mathrm{R}$ & & $\mathrm{R}$ & & & $\mathrm{P}$ & & $P$ & & \\
\hline $22 X-C C$ & 199.04 & $M$ & C & & & $\mathrm{R}$ & & & & $\mathrm{R}$ & $\mathrm{F}$ & & $\mathrm{R}$ & & C & $\mathrm{R}$ & & $\mathrm{R}$ & & $\mathrm{R}$ & & \\
\hline $23 X-C C$ & 211.87 & G & A & & & $\mathrm{F}$ & & $\mathrm{F}$ & & $\mathrm{F}$ & C & & & & $\mathrm{A}$ & $\mathrm{R}$ & & C & $P$ & $\mathrm{R}$ & $\mathrm{F}$ & $=$ \\
\hline $24 \mathrm{X}-\mathrm{CC}$ & 225.73 & G & A & $\mathrm{R}$ & & $\mathrm{R}$ & $\mathrm{R}$ & $\mathrm{R}$ & & & & & $\mathrm{F}$ & $\mathrm{F}$ & A & $\mathrm{F}$ & & C & $R$ & A & $\mathrm{R}$ & $R$ \\
\hline $\begin{array}{l}\text { 339-U1388C- } \\
\text { 3R-CC }\end{array}$ & 222.55 & $M$ & VA & & & $\mathrm{R}$ & & $\mathrm{F}$ & & P & $\mathrm{R}$ & $\mathrm{F}$ & $\mathrm{F}$ & $\mathrm{R}$ & $\mathrm{D}$ & $R$ & & C & & D & & \\
\hline
\end{tabular}

Preservation: $\mathrm{G}=$ good, $\mathrm{M}=$ medium. Abundance: $\mathrm{D}=$ dominant, $\mathrm{VA}=$ very abundant, $\mathrm{A}=$ abundant, $\mathrm{C}=\mathrm{common}, \mathrm{F}=$ few, $\mathrm{R}=$ rare, $\mathrm{P}=$ present, B = barren. See "Biostratigraphy" in the "Methods" chapter (Expedition 339 Scientists, $2013 \mathrm{~b}$ ) for abundance and preservation definitions. 


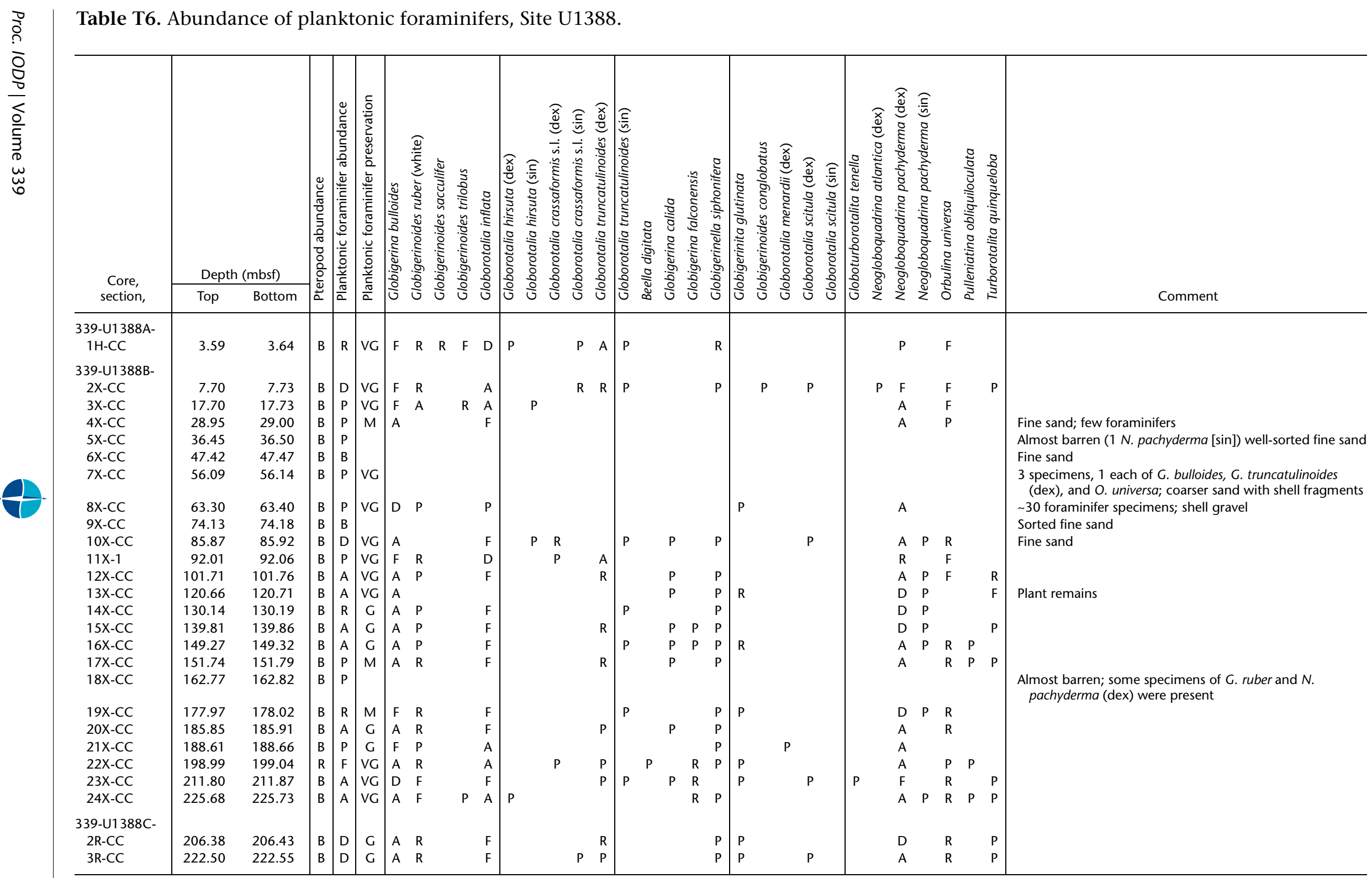

Abundance: $D=$ dominant, $A=$ abundant, $F=$ few, $P=$ present, $R=$ rare, $B=$ barren. Preservation: $V G=$ very good, $G=$ good, $M=$ moderate. sin $=$ sinistral, dex $=$ dextral. See "Biostratigraphy" in the "Methods" chapter (Expedition 339 Scientists, 2013b) for abundance and preservation definitions. 
Table T7. Abundance of benthic foraminifers, Site U1388. (Continued on next two pages.)

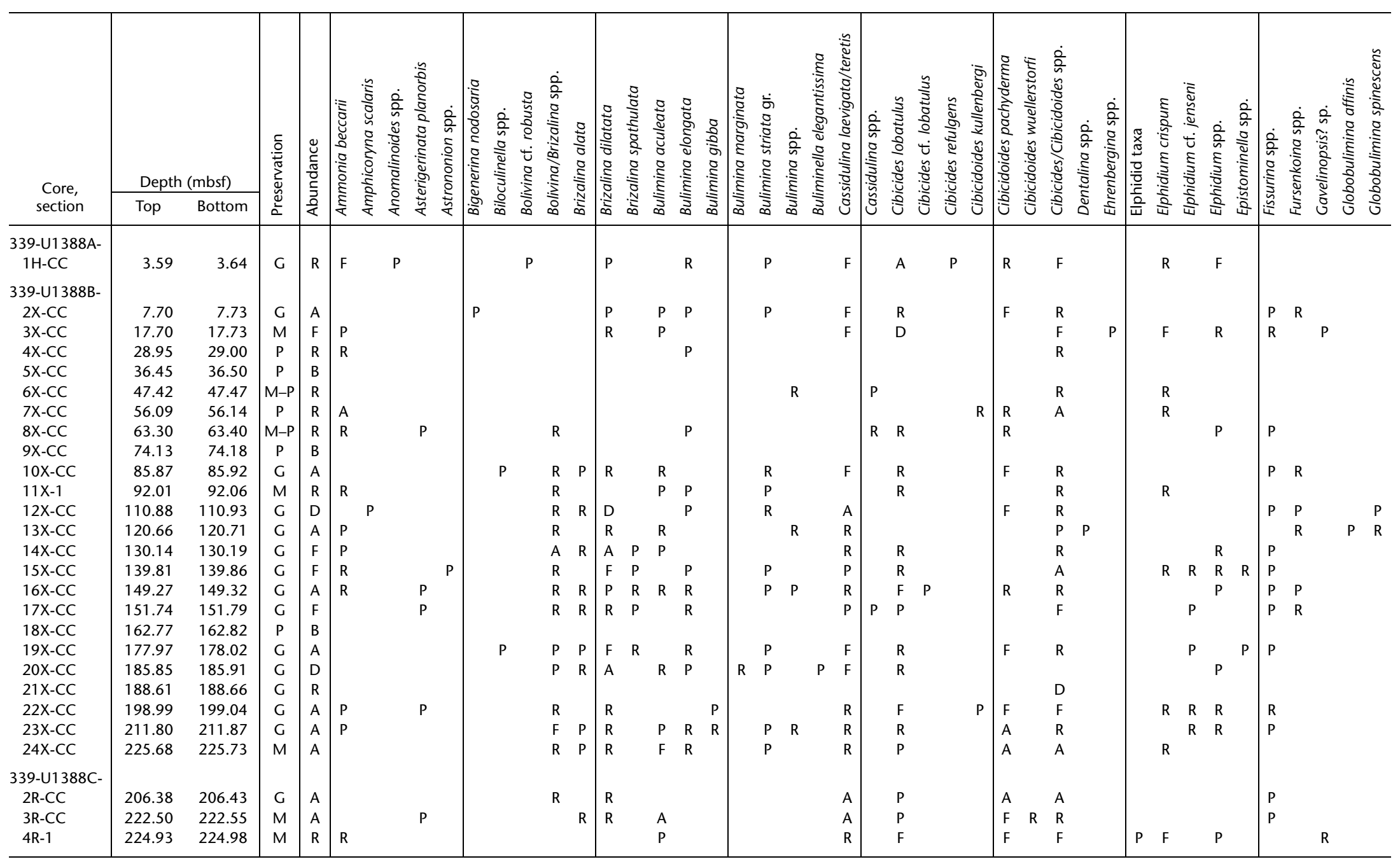

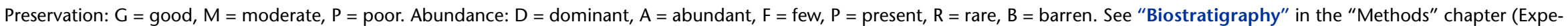
dition 339 Scientists, 2013b) for abundance and preservation definitions. 


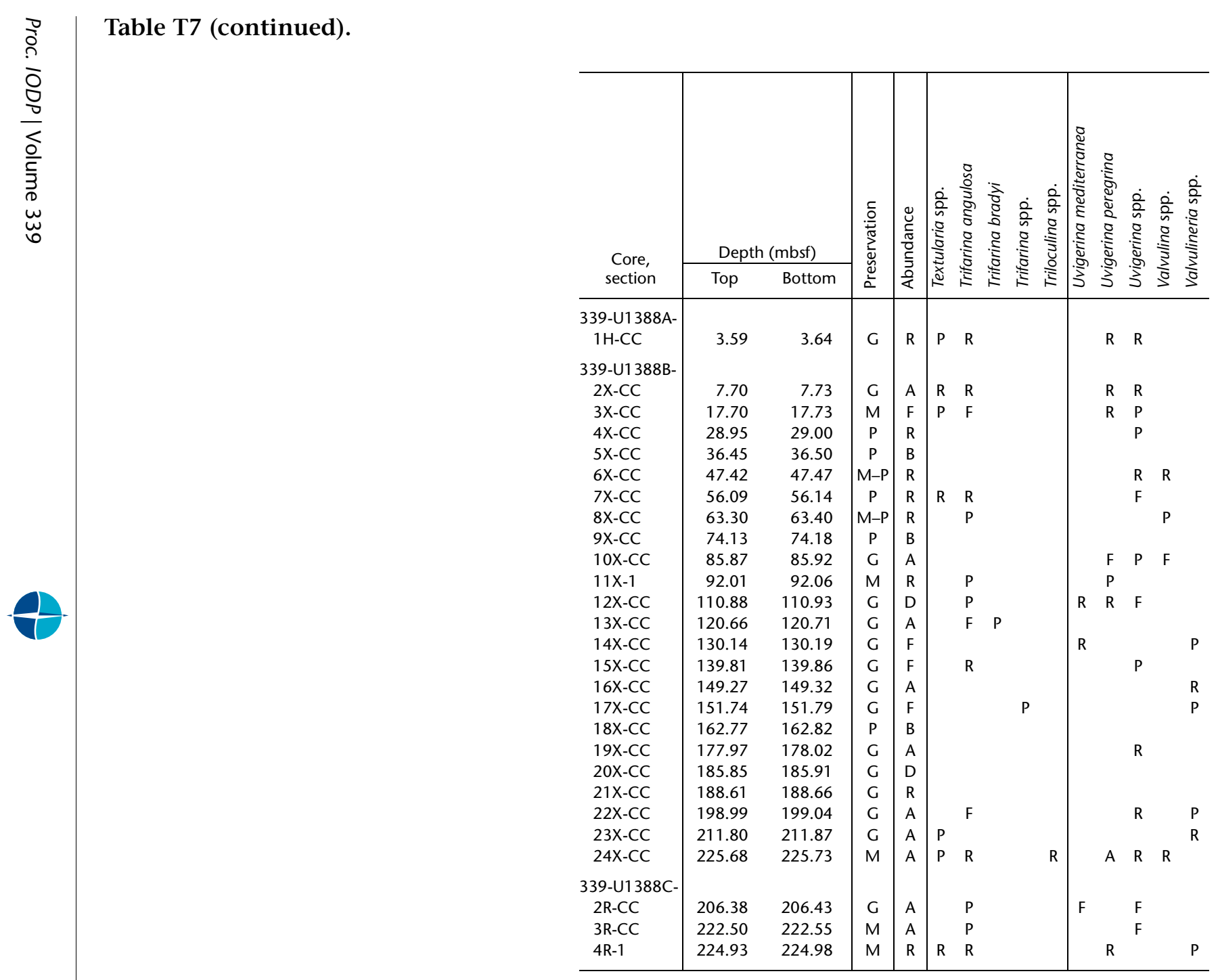


Table T8. Abundance of pollen and spores, Hole U1388B.

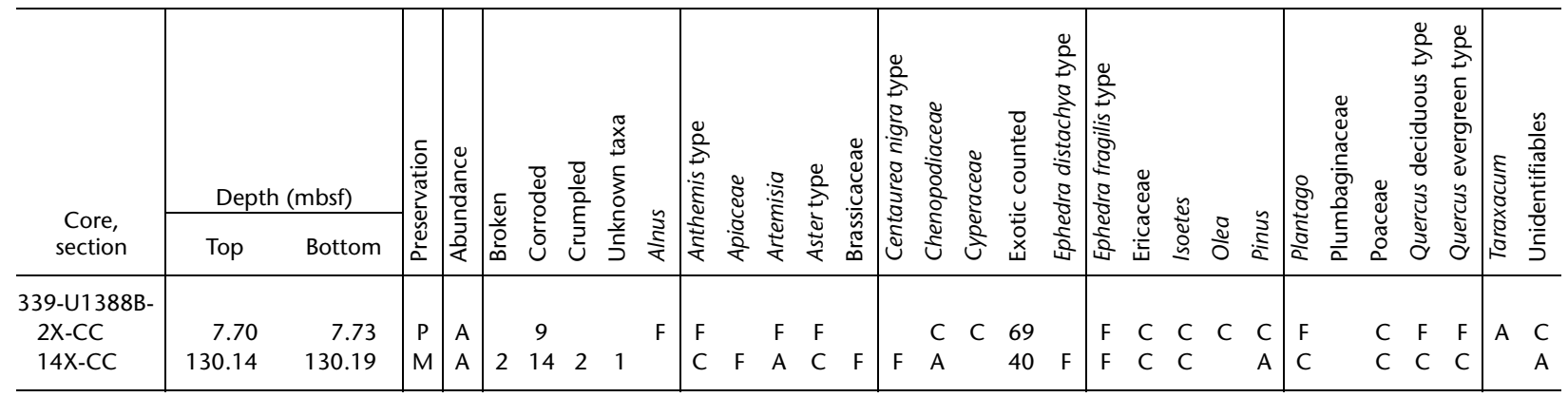

Preservation: $\mathrm{M}=$ moderate, $\mathrm{P}=$ poor. Abundance: $\mathrm{A}=$ abundant, $\mathrm{C}=$ common, $\mathrm{F}=$ few. See "Biostratigraphy" in the "Methods" chapter (Expedition 339 Scientists, 2013b) for abundance and preservation definitions.

Table T9. Core disturbance intervals, Site U1388.

\begin{tabular}{|c|c|c|c|}
\hline \multirow{2}{*}{$\begin{array}{l}\text { Core, } \\
\text { section }\end{array}$} & \multicolumn{2}{|c|}{$\begin{array}{l}\text { Offset of disturbed } \\
\text { interval }(\mathrm{cm})\end{array}$} & \multirow{2}{*}{$\begin{array}{l}\text { Type of } \\
\text { disturbance }\end{array}$} \\
\hline & Top & Bottom & \\
\hline \multicolumn{4}{|l|}{ 339-U1388A- } \\
\hline 1A-1 & 0 & 70 & Core top/Soupy \\
\hline $1 \mathrm{~A}-2$ & 125 & 135 & IW \\
\hline \multicolumn{4}{|l|}{ 339-U1388B- } \\
\hline $6 \mathrm{X}-1$ & 145 & 150 & IW \\
\hline $7 X-1$ & 0 & 65 & Disturbed \\
\hline $10 \mathrm{X}-1$ & 145 & 150 & IW \\
\hline $12 X-4$ & 145 & 150 & IW \\
\hline $13 X-6$ & 145 & 150 & IW \\
\hline $14 X-5$ & 145 & 150 & IW \\
\hline $15 X-5$ & 145 & 150 & IW \\
\hline $16 X-5$ & 145 & 150 & IW \\
\hline $17 X-1$ & 0 & 20 & Core top \\
\hline $17 X-1$ & 145 & 150 & IW \\
\hline $18 \mathrm{X}-1$ & 0 & 10 & Core top \\
\hline $18 \mathrm{X}-1$ & 145 & 150 & IW \\
\hline $19 X-6$ & 125 & 135 & IW \\
\hline $20 X-1$ & 0 & 10 & Core top \\
\hline $20 X-5$ & 125 & 130 & IW \\
\hline $21 X-1$ & 0 & 17 & Core top \\
\hline $22 \mathrm{X}-1$ & 0 & 5 & Core top \\
\hline $23 X-3$ & 140 & 145 & IW \\
\hline $\begin{array}{l}339-U 1388 \mathrm{C}- \\
2 \mathrm{R}-1\end{array}$ & 0 & 15 & Core top \\
\hline
\end{tabular}

IW = interstitial water sample. 
Table T10. NRM inclination, declination, and intensity data after $20 \mathrm{mT}$ peak field AF demagnetization, Hole U1388A. (Continued on next page.)

\begin{tabular}{|c|c|c|c|c|c|}
\hline $\begin{array}{l}\text { Core, section, } \\
\text { interval }(\mathrm{cm})\end{array}$ & $\begin{array}{l}\text { Depth } \\
\text { (mbsf) }\end{array}$ & $\begin{array}{l}\text { Inclination } \\
\left({ }^{\circ}\right)\end{array}$ & $\begin{array}{c}\text { Declination } \\
\left({ }^{\circ}\right)\end{array}$ & $\begin{array}{c}\text { Flexlt- } \\
\text { corrected } \\
\text { declination } \\
\left(^{\circ}\right)\end{array}$ & $\begin{array}{l}\text { Intensity } \\
(\mathrm{A} / \mathrm{m})\end{array}$ \\
\hline \multicolumn{6}{|l|}{ 339-U1388A- } \\
\hline $1 \mathrm{H}-1$ & 0.00 & & & & \\
\hline $1 \mathrm{H}-1,5$ & 0.05 & & & & \\
\hline $1 \mathrm{H}-1,10$ & 0.10 & & & & \\
\hline $1 \mathrm{H}-1,15$ & 0.15 & -65.1 & 218.7 & & 0.00106 \\
\hline $1 \mathrm{H}-1,20$ & 0.20 & -67.1 & 229.3 & & 0.001155 \\
\hline $1 \mathrm{H}-1,25$ & 0.25 & -68.7 & 237.2 & & 0.001306 \\
\hline $1 \mathrm{H}-1,30$ & 0.30 & -72.7 & 277.8 & & 0.001199 \\
\hline $1 \mathrm{H}-1,35$ & 0.35 & -69.2 & 339.7 & & 0.0007429 \\
\hline $1 \mathrm{H}-1,40$ & 0.40 & -72.6 & 40.1 & & 0.0003739 \\
\hline $1 \mathrm{H}-1,45$ & 0.45 & -57.4 & 19.5 & & 0.000595 \\
\hline $1 \mathrm{H}-1,50$ & 0.50 & -49.1 & 321.3 & & 0.0007535 \\
\hline $1 \mathrm{H}-1,55$ & 0.55 & -13.4 & 335.7 & & 0.0006154 \\
\hline $1 \mathrm{H}-1,60$ & 0.60 & 13.3 & 321.6 & & 0.0004347 \\
\hline $1 \mathrm{H}-1,65$ & 0.65 & 76.1 & 226.2 & & 0.0001293 \\
\hline $1 \mathrm{H}-1,70$ & 0.70 & 42.2 & 67 & & 0.0002901 \\
\hline $1 \mathrm{H}-1,75$ & 0.75 & 44.3 & 88.9 & & 0.0005917 \\
\hline $1 \mathrm{H}-1,80$ & 0.80 & 80.2 & 57.9 & & 0.001829 \\
\hline $1 \mathrm{H}-1,85$ & 0.85 & 48.5 & 291.8 & & 0.003722 \\
\hline $1 \mathrm{H}-1,90$ & 0.90 & 23.5 & 283 & & 0.001729 \\
\hline $1 \mathrm{H}-1,95$ & 0.95 & 17.7 & 218.6 & & 0.000453 \\
\hline $1 \mathrm{H}-1,100$ & 1.00 & -12.9 & 229.8 & & 0.0003069 \\
\hline $1 \mathrm{H}-1,105$ & 1.05 & -2.5 & 234.5 & & 0.0002894 \\
\hline $1 \mathrm{H}-1,110$ & 1.10 & 35.4 & 112.2 & & 0.000222 \\
\hline $1 \mathrm{H}-1,115$ & 1.15 & 30.4 & 126.9 & & 0.0002784 \\
\hline $1 \mathrm{H}-1,120$ & 1.20 & 15.5 & 129.3 & & 0.0002311 \\
\hline $1 \mathrm{H}-1,125$ & 1.25 & 17.1 & 167.4 & & 0.0001011 \\
\hline $1 \mathrm{H}-1,130$ & 1.30 & 37 & 273.8 & & 0.0002429 \\
\hline $1 \mathrm{H}-1,135$ & 1.35 & 77.9 & 286.5 & & 0.0003679 \\
\hline $1 \mathrm{H}-1,140$ & 1.40 & & & & \\
\hline $1 \mathrm{H}-1,145$ & 1.45 & & & & \\
\hline $1 \mathrm{H}-1,150$ & 1.50 & & & & \\
\hline $1 \mathrm{H}-2$ & 1.50 & & & & \\
\hline $1 \mathrm{H}-2,5$ & 1.55 & & & & \\
\hline $1 \mathrm{H}-2,10$ & 1.60 & & & & \\
\hline $1 \mathrm{H}-2,15$ & 1.65 & 73.9 & 281.1 & & 0.0005715 \\
\hline $1 \mathrm{H}-2,20$ & 1.70 & 56 & 283 & & 0.0005796 \\
\hline $1 \mathrm{H}-2,25$ & 1.75 & 60.6 & 274.6 & & 0.0005386 \\
\hline $1 \mathrm{H}-2,30$ & 1.80 & 44.5 & 261.5 & & 0.0007555 \\
\hline $1 \mathrm{H}-2,35$ & 1.85 & 47.6 & 257 & & 0.0009471 \\
\hline $1 \mathrm{H}-2,40$ & 1.90 & 76 & 219.5 & & 0.0009221 \\
\hline $1 \mathrm{H}-2,45$ & 1.95 & 61.6 & 272.9 & & 0.001032 \\
\hline $1 \mathrm{H}-2,50$ & 2.00 & 74.8 & 240.6 & & 0.00101 \\
\hline $1 \mathrm{H}-2,55$ & 2.05 & 66.5 & 206.9 & & 0.0008087 \\
\hline $1 \mathrm{H}-2,60$ & 2.10 & 42.3 & 246.4 & & 0.0007146 \\
\hline $1 \mathrm{H}-2,65$ & 2.15 & 50 & 207.9 & & 0.0007026 \\
\hline $1 \mathrm{H}-2,70$ & 2.20 & 61.8 & 176.1 & & 0.0006899 \\
\hline $1 \mathrm{H}-2,75$ & 2.25 & 51.3 & 256.6 & & 0.0008523 \\
\hline $1 \mathrm{H}-2,80$ & 2.30 & 25.9 & 271.3 & & 0.001523 \\
\hline $1 \mathrm{H}-2,85$ & 2.35 & 37.2 & 263.1 & & 0.0009578 \\
\hline $1 \mathrm{H}-2,90$ & 2.40 & 44 & 180.7 & & 0.0007373 \\
\hline $1 \mathrm{H}-2,95$ & 2.45 & 40.8 & 194.3 & & 0.0009692 \\
\hline $1 \mathrm{H}-2,100$ & 2.50 & 56.2 & 157.7 & & 0.0008753 \\
\hline $1 \mathrm{H}-2,105$ & 2.55 & 71.1 & 174.9 & & 0.000762 \\
\hline $1 \mathrm{H}-2,110$ & 2.60 & 62.7 & 224.8 & & 0.000684 \\
\hline $1 \mathrm{H}-2,115$ & 2.65 & 62.8 & 165.8 & & 0.0004401 \\
\hline $1 \mathrm{H}-2,120$ & 2.70 & & & & \\
\hline $1 \mathrm{H}-2,125$ & 2.75 & & & & \\
\hline $1 \mathrm{H}-2,130$ & 2.80 & & & & \\
\hline $1 \mathrm{H}-3$ & 2.81 & & & & \\
\hline $1 \mathrm{H}-3,5$ & 2.86 & & & & \\
\hline $1 \mathrm{H}-3,10$ & 2.91 & & & & \\
\hline $1 \mathrm{H}-3,15$ & 2.96 & 54.6 & 215.8 & & 0.0004363 \\
\hline $1 \mathrm{H}-3,20$ & 3.01 & 37.6 & 220.4 & & 0.0005674 \\
\hline $1 \mathrm{H}-3,25$ & 3.06 & 36.6 & 214.9 & & 0.0004845 \\
\hline $1 \mathrm{H}-3,30$ & 3.11 & 45.3 & 209.7 & & 0.0005455 \\
\hline
\end{tabular}


Table T10 (continued).

\begin{tabular}{|c|c|c|c|c|c|}
\hline $\begin{array}{l}\text { Core, section, } \\
\text { interval }(\mathrm{cm})\end{array}$ & $\begin{array}{l}\text { Depth } \\
\text { (mbsf) }\end{array}$ & $\begin{array}{c}\text { Inclination } \\
\left({ }^{\circ}\right)\end{array}$ & $\begin{array}{c}\text { Declination } \\
\left({ }^{\circ}\right)\end{array}$ & $\begin{array}{c}\text { Flexlt- } \\
\text { corrected } \\
\text { declination } \\
\left(^{\circ}\right)\end{array}$ & $\begin{array}{l}\text { Intensity } \\
(\mathrm{A} / \mathrm{m})\end{array}$ \\
\hline $1 \mathrm{H}-3,35$ & 3.16 & 33.9 & 253.1 & & 0.0006703 \\
\hline $1 \mathrm{H}-3,40$ & 3.21 & 25.8 & 264.2 & & 0.0003908 \\
\hline $1 \mathrm{H}-3,45$ & 3.26 & 60.4 & 13.9 & & $7.78 \mathrm{E}-05$ \\
\hline $1 \mathrm{H}-3,50$ & 3.31 & & & & \\
\hline $1 \mathrm{H}-3,55$ & 3.36 & & & & \\
\hline $1 \mathrm{H}-3,60$ & 3.41 & & & & \\
\hline
\end{tabular}

Blank cells indicate depth levels where data were either not available (i.e., Flexlt-corrected declination data for nonoriented cores) or removed because of disturbance, voids, or measurement edge effects.

Table T11. NRM inclination, declination, and intensity data after $20 \mathrm{mT}$ peak field AF demagnetization, Hole U1388B. (Continued on next page.)

\begin{tabular}{|c|c|c|c|c|c|}
\hline $\begin{array}{l}\text { Core, section, } \\
\text { interval }(\mathrm{cm})\end{array}$ & $\begin{array}{l}\text { Depth } \\
\text { (mbsf) }\end{array}$ & $\begin{array}{c}\text { Inclination } \\
\left({ }^{\circ}\right)\end{array}$ & $\begin{array}{l}\text { Declination } \\
\left({ }^{\circ}\right)\end{array}$ & $\begin{array}{c}\text { Flexlt- } \\
\text { corrected } \\
\text { declination } \\
\left(^{\circ}\right)\end{array}$ & $\begin{array}{l}\text { Intensity } \\
(\mathrm{A} / \mathrm{m})\end{array}$ \\
\hline \multicolumn{6}{|l|}{ 339-U1388B- } \\
\hline $4 \mathrm{X}-1$ & 26.50 & & & & \\
\hline $4 X-1,5$ & 26.55 & & & & \\
\hline $4 \mathrm{X}-1,10$ & 26.60 & & & & \\
\hline $4 X-1,15$ & 26.65 & 72.3 & 349.6 & & 0.009223 \\
\hline $4 X-1,20$ & 26.70 & 77.8 & 310.4 & & 0.015849 \\
\hline $4 X-1,25$ & 26.75 & 71.7 & 87.4 & & 0.022768 \\
\hline $4 X-1,30$ & 26.80 & 58.1 & 78.8 & & 0.025235 \\
\hline $4 X-1,35$ & 26.85 & 43.7 & 49.9 & & 0.028365 \\
\hline $4 X-1,40$ & 26.90 & 46.1 & 33 & & 0.02617 \\
\hline $4 X-1,45$ & 26.95 & 47.2 & 30.9 & & 0.025975 \\
\hline $4 X-1,50$ & 27.00 & 46.9 & 31.9 & & 0.024234 \\
\hline $4 X-1,55$ & 27.05 & 44.3 & 36.4 & & 0.023023 \\
\hline $4 X-1,60$ & 27.10 & 43.7 & 36.1 & & 0.020811 \\
\hline $4 X-1,65$ & 27.15 & 31.9 & 39.7 & & 0.024083 \\
\hline $4 X-1,70$ & 27.20 & 32.5 & 34 & & 0.024716 \\
\hline $4 X-1,75$ & 27.25 & 39.3 & 27 & & 0.020611 \\
\hline $4 X-1,80$ & 27.30 & 40.6 & 34.1 & & 0.018564 \\
\hline $4 X-1,85$ & 27.35 & 38.1 & 40.9 & & 0.020521 \\
\hline $4 X-1,90$ & 27.40 & 41.9 & 36.7 & & 0.018249 \\
\hline $4 X-1,95$ & 27.45 & 46.7 & 50.1 & & 0.014409 \\
\hline $4 X-1,100$ & 27.50 & 44.1 & 54.2 & & 0.013357 \\
\hline $4 \mathrm{X}-1,105$ & 27.55 & 52 & 28.6 & & 0.006898 \\
\hline $4 X-1,110$ & 27.60 & -71.7 & 129.6 & & 0.003728 \\
\hline $4 X-1,115$ & 27.65 & -45.3 & 95.8 & & 0.012772 \\
\hline $4 \mathrm{X}-1,120$ & 27.70 & -50.4 & 63.5 & & 0.006727 \\
\hline $4 \mathrm{X}-1,125$ & 27.75 & 48.2 & 4.7 & & 0.004267 \\
\hline $4 \mathrm{X}-1,130$ & 27.80 & 52.9 & 38.4 & & 0.016958 \\
\hline $4 X-1,135$ & 27.85 & 49.8 & 45.2 & & 0.026873 \\
\hline $4 \mathrm{X}-1,140$ & 27.90 & & & & \\
\hline $4 \mathrm{X}-1,145$ & 27.95 & & & & \\
\hline $4 X-1,150$ & 28.00 & & & & \\
\hline $4 X-2$ & 28.00 & & & & \\
\hline $4 X-2,5$ & 28.05 & & & & \\
\hline $4 \mathrm{X}-2,10$ & 28.10 & & & & \\
\hline $4 X-2,15$ & 28.15 & 44.5 & 41.7 & & 0.02283 \\
\hline $4 X-2,20$ & 28.20 & 48.9 & 45.7 & & 0.021379 \\
\hline $4 X-2,25$ & 28.25 & 41.8 & 44.3 & & 0.021577 \\
\hline $4 X-2,30$ & 28.30 & 39.5 & 43.4 & & 0.020019 \\
\hline $4 X-2,35$ & 28.35 & 42.9 & 45 & & 0.017474 \\
\hline $4 X-2,40$ & 28.40 & 43.8 & 46.7 & & 0.017344 \\
\hline $4 X-2,45$ & 28.45 & 42.6 & 38.7 & & 0.023387 \\
\hline $4 X-2,50$ & 28.50 & 65.4 & 29 & & 0.027221 \\
\hline $4 X-2,55$ & 28.55 & & & & \\
\hline $4 X-2,60$ & 28.60 & & & & \\
\hline $4 X-2,65$ & 28.65 & & & & \\
\hline
\end{tabular}


Table T11 (continued).

\begin{tabular}{lccccc}
\hline $\begin{array}{c}\text { Core, section, } \\
\text { interval (cm) }\end{array}$ & $\begin{array}{c}\text { Depth } \\
(\mathrm{mbsf})\end{array}$ & $\begin{array}{c}\text { Inclination } \\
\left({ }^{\circ}\right)\end{array}$ & $\begin{array}{c}\text { Declination } \\
\left({ }^{\circ}\right)\end{array}$ & $\begin{array}{c}\text { Flexlt- } \\
\text { corrected } \\
\text { declination } \\
\left({ }^{\circ}\right)\end{array}$ & $\begin{array}{c}\text { Intensity } \\
(\mathrm{A} / \mathrm{m})\end{array}$ \\
\hline $5 \mathrm{X}-1$ & 35.60 & & & & \\
$5 \mathrm{X}-1,5$ & 35.65 & & & & \\
$5 \mathrm{X}-1,10$ & 35.70 & & & & \\
$5 \mathrm{X}-1,15$ & 35.75 & 46 & 72.2 & & 0.004513 \\
$5 \mathrm{X}-1,20$ & 35.80 & 45.4 & 59.2 & & \\
$5 \mathrm{X}-1,25$ & 35.85 & 72.6 & 73 & & \\
$5 \mathrm{X}-1,30$ & 35.90 & & & & \\
$5 \mathrm{X}-1,35$ & 35.95 & & & & \\
$5 \mathrm{X}-1,40$ & 36.00 & & & & \\
$6 \mathrm{X}-1$ & 45.00 & & & & \\
$6 \mathrm{X}-1,5$ & 45.05 & & & & \\
$6 \mathrm{X}-1,10$ & 45.10 & & & & \\
$6 \mathrm{X}-1,15$ & 45.15 & 61.6 & 53.9 & & \\
\hline
\end{tabular}

Blank cells indicate depth levels where data were either not available (i.e., Flexlt-corrected declination data for nonoriented cores) or removed because of disturbance, voids, or measurement edge effects. Only a portion of this table appears here. The complete table is available in ASCII.

Table T12. NRM inclination, declination, and intensity data after $20 \mathrm{mT}$ peak field AF demagnetization, Hole U1388C. (Continued on next three pages.)

\begin{tabular}{|c|c|c|c|c|c|}
\hline $\begin{array}{l}\text { Core, section, } \\
\text { interval }(\mathrm{cm})\end{array}$ & $\begin{array}{l}\text { Depth } \\
\text { (mbst) }\end{array}$ & $\begin{array}{c}\text { Inclination } \\
\left({ }^{\circ}\right)\end{array}$ & $\begin{array}{l}\text { Declination } \\
\left({ }^{\circ}\right)\end{array}$ & $\begin{array}{c}\text { Flexlt- } \\
\text { corrected } \\
\text { declination } \\
\left(^{\circ}\right)\end{array}$ & $\begin{array}{c}\text { Intensity } \\
(\mathrm{A} / \mathrm{m})\end{array}$ \\
\hline \multicolumn{6}{|l|}{ 339-U1388C- } \\
\hline $2 \mathrm{R}-1$ & 205 & & & & \\
\hline $2 \mathrm{R}-1,5$ & 205.05 & & & & \\
\hline $2 \mathrm{R}-1,10$ & 205.1 & & & & \\
\hline $2 \mathrm{R}-1,15$ & 205.15 & & & & \\
\hline $2 \mathrm{R}-1,20$ & 205.2 & 52.8 & 161.3 & & 0.006113 \\
\hline $2 \mathrm{R}-1,25$ & 205.25 & 59 & 164.5 & & 0.003455 \\
\hline $2 \mathrm{R}-1,30$ & 205.3 & 68.7 & 159.6 & & 0.002239 \\
\hline $2 \mathrm{R}-1,35$ & 205.35 & 66.1 & 144.5 & & 0.002079 \\
\hline $2 \mathrm{R}-1,40$ & 205.4 & 58.9 & 145.7 & & 0.003044 \\
\hline $2 \mathrm{R}-1,45$ & 205.45 & 54 & 156.2 & & 0.003974 \\
\hline $2 \mathrm{R}-1,50$ & 205.5 & 53.5 & 128.8 & & 0.004299 \\
\hline $2 \mathrm{R}-1,55$ & 205.55 & 51.2 & 70.5 & & 0.004836 \\
\hline $2 \mathrm{R}-1,60$ & 205.6 & 75.3 & 337 & & 0.004742 \\
\hline $2 \mathrm{R}-1,65$ & 205.65 & 63 & 237.3 & & 0.006159 \\
\hline $2 \mathrm{R}-1,70$ & 205.7 & 59.3 & 209.4 & & 0.006805 \\
\hline $2 \mathrm{R}-1,75$ & 205.75 & 78.7 & 8.2 & & 0.004972 \\
\hline $2 \mathrm{R}-1,80$ & 205.8 & 57.3 & 337.9 & & 0.006745 \\
\hline $2 \mathrm{R}-1,85$ & 205.85 & 51.8 & 284.7 & & 0.007943 \\
\hline $2 \mathrm{R}-1,90$ & 205.9 & 53.2 & 269.5 & & 0.007954 \\
\hline $2 \mathrm{R}-1,95$ & 205.95 & 56.4 & 267.6 & & 0.005534 \\
\hline $2 \mathrm{R}-1,100$ & 206 & 64.4 & 272.4 & & 0.003558 \\
\hline $2 \mathrm{R}-1,105$ & 206.05 & 65.4 & 272.4 & & 0.002657 \\
\hline $2 \mathrm{R}-1,110$ & 206.1 & 64.5 & 271.5 & & 0.002577 \\
\hline 2R-1, 115 & 206.15 & 60.1 & 272.5 & & 0.002649 \\
\hline $2 \mathrm{R}-1,120$ & 206.2 & & & & \\
\hline $2 \mathrm{R}-1,125$ & 206.25 & & & & \\
\hline $2 \mathrm{R}-1,130$ & 206.3 & & & & \\
\hline $3 R-1$ & 214.5 & & & & \\
\hline $3 \mathrm{R}-1,5$ & 214.55 & & & & \\
\hline $3 \mathrm{R}-1,10$ & 214.6 & & & & \\
\hline $3 R-1,15$ & 214.65 & 65.5 & 31.1 & & 0.015627 \\
\hline $3 \mathrm{R}-1,20$ & 214.7 & 81.7 & 213.5 & & 0.00576 \\
\hline $3 \mathrm{R}-1,25$ & 214.75 & 86.8 & 343.3 & & 0.002888 \\
\hline $3 R-1,30$ & 214.8 & 66.6 & 105.3 & & 0.002958 \\
\hline $3 R-1,35$ & 214.85 & 56.5 & 52.5 & & 0.00323 \\
\hline $3 \mathrm{R}-1,40$ & 214.9 & 64.7 & 358.3 & & 0.00264 \\
\hline $3 \mathrm{R}-1,45$ & 214.95 & 65.6 & 113.5 & & 0.002335 \\
\hline $3 \mathrm{R}-1,50$ & 215 & 68.6 & 114.6 & & 0.002412 \\
\hline
\end{tabular}


Table T12 (continued). (Continued on next page.)

\begin{tabular}{|c|c|c|c|c|c|}
\hline $\begin{array}{l}\text { Core, section, } \\
\text { interval }(\mathrm{cm})\end{array}$ & $\begin{array}{l}\text { Depth } \\
\text { (mbsf) }\end{array}$ & $\begin{array}{l}\text { Inclination } \\
\left({ }^{\circ}\right)\end{array}$ & $\begin{array}{c}\text { Declination } \\
\left({ }^{\circ}\right)\end{array}$ & $\begin{array}{c}\text { Flexlt- } \\
\text { corrected } \\
\text { declination } \\
\left(^{\circ}\right)\end{array}$ & $\begin{array}{l}\text { Intensity } \\
(\mathrm{A} / \mathrm{m})\end{array}$ \\
\hline $3 R-1,55$ & 215.05 & 81.1 & 286.5 & & 0.002168 \\
\hline $3 R-1,60$ & 215.1 & 88.6 & 21.2 & & 0.002097 \\
\hline $3 R-1,65$ & 215.15 & 74 & 215.5 & & 0.002238 \\
\hline $3 \mathrm{R}-1,70$ & 215.2 & 74.6 & 313.7 & & 0.002255 \\
\hline $3 \mathrm{R}-1,75$ & 215.25 & 60.8 & 19.2 & & 0.00245 \\
\hline $3 \mathrm{R}-1,80$ & 215.3 & 69.4 & 149.8 & & 0.002166 \\
\hline $3 \mathrm{R}-1,85$ & 215.35 & 58.1 & 164.1 & & 0.002084 \\
\hline $3 \mathrm{R}-1,90$ & 215.4 & 61.5 & 84.2 & & 0.002159 \\
\hline $3 R-1,95$ & 215.45 & 52.2 & 44.3 & & 0.002581 \\
\hline $3 R-1,100$ & 215.5 & 53.2 & 63.6 & & 0.002613 \\
\hline $3 R-1,105$ & 215.55 & 66.6 & 56 & & 0.002327 \\
\hline $3 \mathrm{R}-1,110$ & 215.6 & 71.7 & 296.7 & & 0.002228 \\
\hline $3 R-1,115$ & 215.65 & 66.4 & 309.7 & & 0.002383 \\
\hline $3 \mathrm{R}-1,120$ & 215.7 & 87 & 332 & & 0.002199 \\
\hline $3 R-1,125$ & 215.75 & 85.8 & 200 & & 0.002142 \\
\hline $3 R-1,130$ & 215.8 & 76.1 & 33 & & 0.001984 \\
\hline $3 R-1,135$ & 215.85 & 59.6 & 31.3 & & 0.002324 \\
\hline $3 R-1,140$ & 215.9 & & & & \\
\hline $3 R-1,145$ & 215.95 & & & & \\
\hline $3 R-1,150$ & 216 & & & & \\
\hline $3 R-2$ & 216 & & & & \\
\hline $3 \mathrm{R}-2,5$ & 216.05 & & & & \\
\hline $3 R-2,10$ & 216.1 & & & & \\
\hline $3 R-2,15$ & 216.15 & 43.9 & 140.3 & & 0.01508 \\
\hline $3 R-2,20$ & 216.2 & 72.5 & 163.1 & & 0.004552 \\
\hline $3 R-2,25$ & 216.25 & 45.2 & 352.2 & & 0.002944 \\
\hline $3 R-2,30$ & 216.3 & 56.3 & 10.8 & & 0.002771 \\
\hline $3 R-2,35$ & 216.35 & 77.3 & 226.3 & & 0.003549 \\
\hline $3 R-2,40$ & 216.4 & 64.9 & 198.1 & & 0.003315 \\
\hline $3 R-2,45$ & 216.45 & 60.3 & 137.4 & & 0.003296 \\
\hline $3 R-2,50$ & 216.5 & 63.3 & 78 & & 0.003034 \\
\hline $3 R-2,55$ & 216.55 & 65.5 & 348.5 & & 0.00322 \\
\hline $3 R-2,60$ & 216.6 & 75.5 & 0.5 & & 0.003568 \\
\hline $3 R-2,65$ & 216.65 & 71.9 & 111.4 & & 0.003533 \\
\hline $3 R-2,70$ & 216.7 & 80.3 & 170.4 & & 0.00334 \\
\hline $3 R-2,75$ & 216.75 & 83.5 & 194.9 & & 0.003287 \\
\hline $3 R-2,80$ & 216.8 & 78.3 & 92.2 & & 0.003007 \\
\hline $3 R-2,85$ & 216.85 & 75.5 & 150 & & 0.00327 \\
\hline $3 R-2,90$ & 216.9 & 68.6 & 52.1 & & 0.004968 \\
\hline $3 R-2,95$ & 216.95 & 56 & 45.3 & & 0.006993 \\
\hline $3 R-2,100$ & 217 & 82.7 & 49.1 & & 0.005678 \\
\hline $3 R-2,105$ & 217.05 & 71.8 & 150.9 & & 0.005147 \\
\hline $3 R-2,110$ & 217.1 & 63.3 & 171.9 & & 0.002984 \\
\hline $3 R-2,115$ & 217.15 & 60.1 & 217.3 & & 0.001742 \\
\hline $3 R-2,120$ & 217.2 & 63.5 & 208.2 & & 0.001979 \\
\hline $3 R-2,125$ & 217.25 & 65.6 & 174.4 & & 0.002879 \\
\hline $3 R-2,130$ & 217.3 & 68 & 108.2 & & 0.002808 \\
\hline $3 R-2,135$ & 217.35 & 72.2 & 83 & & 0.003027 \\
\hline $3 R-2,140$ & 217.4 & & & & \\
\hline $3 R-2,145$ & 217.45 & & & & \\
\hline $3 R-2,150$ & 217.5 & & & & \\
\hline $3 R-3$ & 217.5 & & & & \\
\hline $3 R-3,5$ & 217.55 & & & & \\
\hline $3 R-3,10$ & 217.6 & & & & \\
\hline $3 R-3,15$ & 217.65 & 66.4 & 12.7 & & 0.013542 \\
\hline $3 R-3,20$ & 217.7 & 76.1 & 8.3 & & 0.0088 \\
\hline $3 R-3,25$ & 217.75 & 58 & 277.7 & & 0.00578 \\
\hline $3 R-3,30$ & 217.8 & 50.9 & 276.5 & & 0.003401 \\
\hline $3 R-3,35$ & 217.85 & 77.2 & 163.6 & & 0.002219 \\
\hline $3 R-3,40$ & 217.9 & 72.5 & 170.2 & & 0.002274 \\
\hline $3 R-3,45$ & 217.95 & 77.2 & 233.4 & & 0.002074 \\
\hline $3 R-3,50$ & 218 & 77.8 & 275.7 & & 0.002143 \\
\hline $3 R-3,55$ & 218.05 & 72.6 & 44.3 & & 0.00222 \\
\hline $3 R-3,60$ & 218.1 & 69.1 & 13.8 & & 0.00224 \\
\hline $3 R-3,65$ & 218.15 & 73.1 & 201.4 & & 0.0022 \\
\hline $3 R-3,70$ & 218.2 & 57.7 & 166.7 & & 0.002153 \\
\hline $3 R-3,75$ & 218.25 & 25.3 & 99.2 & & 0.004379 \\
\hline
\end{tabular}


Table T12 (continued). (Continued on next page.)

\begin{tabular}{|c|c|c|c|c|c|}
\hline $\begin{array}{l}\text { Core, section, } \\
\text { interval }(\mathrm{cm})\end{array}$ & $\begin{array}{l}\text { Depth } \\
\text { (mbsf) }\end{array}$ & $\begin{array}{l}\text { Inclination } \\
\left({ }^{\circ}\right)\end{array}$ & $\begin{array}{l}\text { Declination } \\
\left({ }^{\circ}\right)\end{array}$ & $\begin{array}{c}\text { Flexlt- } \\
\text { corrected } \\
\text { declination } \\
\left({ }^{\circ}\right)\end{array}$ & $\begin{array}{l}\text { Intensity } \\
(\mathrm{A} / \mathrm{m})\end{array}$ \\
\hline $3 R-3,80$ & 218.3 & 36.8 & 101.7 & & 0.008139 \\
\hline $3 R-3,85$ & 218.35 & 30.7 & 263.7 & & 0.062123 \\
\hline $3 R-3,90$ & 218.4 & 64.4 & 272.7 & & 0.1816 \\
\hline $3 R-3,95$ & 218.45 & 30.4 & 85.1 & & 0.23199 \\
\hline $3 R-3,100$ & 218.5 & 50.2 & 79.7 & & 0.023829 \\
\hline $3 R-3,105$ & 218.55 & 9.7 & 268.3 & & 0.015791 \\
\hline $3 R-3,110$ & 218.6 & 13.7 & 266.9 & & 0.006775 \\
\hline $3 R-3,115$ & 218.65 & 26.9 & 266.7 & & 0.003543 \\
\hline $3 R-3,120$ & 218.7 & 34.5 & 272.6 & & 0.002633 \\
\hline $3 R-3,125$ & 218.75 & 43.3 & 279.7 & & 0.001884 \\
\hline $3 R-3,130$ & 218.8 & 73.4 & 238.7 & & 0.001282 \\
\hline $3 R-3,135$ & 218.85 & 74.4 & 232.4 & & 0.001212 \\
\hline $3 R-3,140$ & 218.9 & & & & \\
\hline $3 R-3,145$ & 218.95 & & & & \\
\hline $3 R-3,150$ & 219 & & & & \\
\hline $3 R-4$ & 219 & & & & \\
\hline $3 R-4,5$ & 219.05 & & & & \\
\hline $3 R-4,10$ & 219.1 & & & & \\
\hline $3 R-4,15$ & 219.15 & 59.8 & 64.3 & & 0.001646 \\
\hline $3 R-4,20$ & 219.2 & 63 & 22.4 & & 0.001583 \\
\hline $3 R-4,25$ & 219.25 & 71.1 & 320.1 & & 0.001501 \\
\hline $3 R-4,30$ & 219.3 & 68.6 & 272.1 & & 0.001448 \\
\hline $3 R-4,35$ & 219.35 & 71.4 & 265.9 & & 0.001247 \\
\hline $3 R-4,40$ & 219.4 & 63 & 169.8 & & 0.001236 \\
\hline $3 R-4,45$ & 219.45 & 55.7 & 163.5 & & 0.001534 \\
\hline $3 R-4,50$ & 219.5 & 62 & 153.2 & & 0.001674 \\
\hline $3 R-4,55$ & 219.55 & 68.5 & 79 & & 0.001568 \\
\hline $3 R-4,60$ & 219.6 & 77.2 & 81.5 & & 0.001443 \\
\hline $3 R-4,65$ & 219.65 & 66.6 & 133.4 & & 0.001414 \\
\hline $3 R-4,70$ & 219.7 & 75.5 & 201.3 & & 0.001272 \\
\hline $3 R-4,75$ & 219.75 & 62 & 255.8 & & 0.00145 \\
\hline $3 R-4,80$ & 219.8 & 59.4 & 257.4 & & 0.001574 \\
\hline $3 R-4,85$ & 219.85 & 67.8 & 239.7 & & 0.001338 \\
\hline $3 R-4,90$ & 219.9 & 73 & 290.9 & & 0.0007623 \\
\hline $3 R-4,95$ & 219.95 & 16.2 & 55.3 & & 0.001548 \\
\hline $3 R-4,100$ & 220 & 38.9 & 53.7 & & 0.001183 \\
\hline $3 R-4,105$ & 220.05 & 67.6 & 298.7 & & 0.0008144 \\
\hline $3 R-4,110$ & 220.1 & 83.7 & 199.4 & & 0.0006512 \\
\hline $3 R-4,115$ & 220.15 & 60.5 & 116.2 & & 0.0006556 \\
\hline $3 R-4,120$ & 220.2 & 70.5 & 69.4 & & 0.0005905 \\
\hline $3 R-4,125$ & 220.25 & 58.2 & 47.6 & & 0.0007036 \\
\hline $3 R-4,130$ & 220.3 & 57.1 & 106.3 & & 0.0007686 \\
\hline $3 R-4,135$ & 220.35 & 60.2 & 131.6 & & 0.0008902 \\
\hline $3 R-4,140$ & 220.4 & & & & \\
\hline $3 R-4,145$ & 220.45 & & & & \\
\hline $3 R-4,150$ & 220.5 & & & & \\
\hline $3 R-5$ & 220.5 & & & & \\
\hline $3 R-5,5$ & 220.55 & & & & \\
\hline $3 R-5,10$ & 220.6 & & & & \\
\hline $3 R-5,15$ & 220.65 & 64.4 & 304.2 & & 0.001152 \\
\hline $3 R-5,20$ & 220.7 & 64.9 & 165.7 & & 0.001439 \\
\hline $3 R-5,25$ & 220.75 & 72.3 & 113.4 & & 0.001456 \\
\hline $3 R-5,30$ & 220.8 & 77.5 & 278.3 & & 0.001205 \\
\hline $3 R-5,35$ & 220.85 & 74.5 & 168.5 & & 0.001182 \\
\hline $3 R-5,40$ & 220.9 & 60.1 & 129 & & 0.001133 \\
\hline $3 R-5,45$ & 220.95 & 63.1 & 75 & & 0.001013 \\
\hline $3 R-5,50$ & 221 & 75.3 & 47.8 & & 0.0009846 \\
\hline $3 R-5,55$ & 221.05 & 73.4 & 154.4 & & 0.001092 \\
\hline $3 R-5,60$ & 221.1 & 78 & 87.4 & & 0.001118 \\
\hline $3 R-5,65$ & 221.15 & 77.7 & 316.5 & & 0.001096 \\
\hline $3 R-5,70$ & 221.2 & 59.6 & 330.5 & & 0.001158 \\
\hline $3 R-5,75$ & 221.25 & 55.1 & 39 & & 0.001208 \\
\hline $3 R-5,80$ & 221.3 & 64.4 & 49.5 & & 0.00163 \\
\hline $3 R-5,85$ & 221.35 & 68.8 & 1.3 & & 0.002857 \\
\hline $3 R-5,90$ & 221.4 & 73.4 & 298.8 & & 0.003582 \\
\hline $3 R-5,95$ & 221.45 & 75.1 & 127.6 & & 0.004156 \\
\hline $3 R-5,100$ & 221.5 & 53 & 90.4 & & 0.006232 \\
\hline
\end{tabular}


Table T12 (continued).

\begin{tabular}{|c|c|c|c|c|c|}
\hline $\begin{array}{l}\text { Core, section, } \\
\text { interval }(\mathrm{cm})\end{array}$ & $\begin{array}{l}\text { Depth } \\
\text { (mbsf) }\end{array}$ & $\begin{array}{l}\text { Inclination } \\
\left(\left(^{\circ}\right)\right.\end{array}$ & $\begin{array}{l}\text { Declination } \\
\left(\left(^{\circ}\right)\right.\end{array}$ & $\begin{array}{c}\text { Flexlt- } \\
\text { corrected } \\
\text { declination } \\
\left(^{\circ}\right)\end{array}$ & $\begin{array}{l}\text { Intensity } \\
(\mathrm{A} / \mathrm{m})\end{array}$ \\
\hline $3 R-5,105$ & 221.55 & 43.4 & 92.6 & & 0.005559 \\
\hline $3 R-5,110$ & 221.6 & 72.9 & 62.5 & & 0.001631 \\
\hline $3 R-5,115$ & 221.65 & 41.3 & 303.4 & & 0.001008 \\
\hline $3 R-5,120$ & 221.7 & 42.8 & 290.3 & & 0.0004953 \\
\hline $3 R-6$ & 221.71 & 73.4 & 296.7 & & 0.0002426 \\
\hline $3 R-6,5$ & 221.76 & 67.1 & 217.8 & & 0.000453 \\
\hline $3 R-6,10$ & 221.81 & 76.4 & 211.6 & & 0.0004401 \\
\hline $3 R-6,15$ & 221.86 & 80.6 & 181.6 & & 0.0004908 \\
\hline $3 R-6,20$ & 221.91 & 61.2 & 73.6 & & 0.0007777 \\
\hline $3 R-6,25$ & 221.96 & 63.8 & 43 & & 0.0007902 \\
\hline $3 R-6,30$ & 222.01 & 71.3 & 13.4 & & 0.0007286 \\
\hline $3 R-6,35$ & 222.06 & 55.6 & 349 & & 0.000904 \\
\hline $3 R-6,40$ & 222.11 & 82.6 & 7.3 & & 0.0008267 \\
\hline $3 R-6,45$ & 222.16 & 61.2 & 152.7 & & 0.00102 \\
\hline $3 R-6,50$ & 222.21 & 80.4 & 159.4 & & 0.0009486 \\
\hline $3 R-6,55$ & 222.26 & 59.2 & 74.5 & & 0.001061 \\
\hline $3 R-6,60$ & 222.31 & & & & \\
\hline $3 R-6,65$ & 222.36 & & & & \\
\hline $3 R-6,70$ & 222.41 & & & & \\
\hline $4 \mathrm{R}-1$ & 224.1 & & & & \\
\hline $4 \mathrm{R}-1,5$ & 224.15 & & & & \\
\hline $4 \mathrm{R}-1,10$ & 224.2 & & & & \\
\hline $4 \mathrm{R}-1,15$ & 224.25 & 55.2 & 123.8 & & 0.003917 \\
\hline $4 \mathrm{R}-1,20$ & 224.3 & 63.6 & 130.4 & & 0.003991 \\
\hline $4 \mathrm{R}-1,25$ & 224.35 & 59 & 127.9 & & 0.00445 \\
\hline $4 \mathrm{R}-1,30$ & 224.4 & 55.8 & 127.9 & & 0.004817 \\
\hline $4 \mathrm{R}-1,35$ & 224.45 & 59 & 122.3 & & 0.00454 \\
\hline $4 \mathrm{R}-1,40$ & 224.5 & 50.5 & 112.6 & & 0.005126 \\
\hline $4 \mathrm{R}-1,45$ & 224.55 & 54.2 & 111.6 & & 0.005309 \\
\hline $4 \mathrm{R}-1,50$ & 224.6 & 71.9 & 268.8 & & 0.005094 \\
\hline $4 \mathrm{R}-1,55$ & 224.65 & 50.3 & 268.1 & & 0.006325 \\
\hline $4 R-1,60$ & 224.7 & 49.7 & 267.8 & & 0.006163 \\
\hline $4 R-1,65$ & 224.75 & 52.7 & 262 & & 0.005771 \\
\hline $4 \mathrm{R}-1,70$ & 224.8 & 60.8 & 171.8 & & 0.004622 \\
\hline $4 \mathrm{R}-1,75$ & 224.85 & & & & \\
\hline $4 \mathrm{R}-1,80$ & 224.9 & & & & \\
\hline $4 \mathrm{R}-1,85$ & 224.95 & & & & \\
\hline
\end{tabular}

Blank cells indicate depth levels where data were either not available (i.e., Flexlt-corrected declination data for nonoriented cores) or removed because of disturbance, voids, or measurement edge effects. 
Table T13. Headspace sample hydrocarbon concentrations, Holes U1388A-U1388C.

\begin{tabular}{|c|c|c|c|c|}
\hline \multirow{2}{*}{$\begin{array}{l}\text { Core, } \\
\text { section }\end{array}$} & \multirow{2}{*}{$\begin{array}{l}\text { Depth } \\
\text { (mbsf) }\end{array}$} & \multicolumn{3}{|c|}{ Concentration (ppmv) } \\
\hline & & Methane & Ethene & Ethane \\
\hline \multicolumn{5}{|l|}{$\begin{array}{l}\text { 339-U1388A- } \\
1 \mathrm{H}-3\end{array}$} \\
\hline \multicolumn{5}{|l|}{ 339-U1388B- } \\
\hline $4 X-2$ & 28.00 & 4.19 & - & - \\
\hline $6 X-2$ & 46.50 & $1,796.75$ & - & - \\
\hline $9 \mathrm{X}-1$ & 73.68 & $12,071.15$ & - & - \\
\hline $10 X-2$ & 83.60 & $26,685.56$ & - & 0.92 \\
\hline $12 X-5$ & 107.30 & $50,377.78$ & - & 1.12 \\
\hline $13 X-7$ & 118.56 & $54,833.61$ & - & 1.27 \\
\hline $14 X-6$ & 127.90 & $35,916.65$ & - & 1.29 \\
\hline $15 X-6$ & 137.40 & $26,584.37$ & - & 0.93 \\
\hline $16 X-6$ & 147.00 & $36,265.22$ & 0.65 & 1.45 \\
\hline $17 X-2$ & 150.60 & $41,816.47$ & 0.69 & 1.64 \\
\hline $18 X-2$ & 160.10 & $65,682.64$ & 0.82 & 2.75 \\
\hline $19 X-7$ & 177.00 & $15,084.71$ & 0.57 & 1.02 \\
\hline $20 X-6$ & 185.07 & $16,709.09$ & - & 1.40 \\
\hline $21 X-1$ & 187.40 & $5,414.54$ & - & - \\
\hline $22 X-2$ & 198.25 & $6,943.99$ & 0.81 & 0.99 \\
\hline $23 X-4$ & 211.00 & $7,981.99$ & - & 1.04 \\
\hline $24 X-7$ & 224.81 & $6,738.78$ & - & 0.82 \\
\hline \multicolumn{5}{|l|}{ 339-U1388C- } \\
\hline $3 R-6$ & 221.71 & $4,861.44$ & 0.71 & 1.49 \\
\hline
\end{tabular}

$-=$ no data.

Table T14. Results from coulometric and CHNS analysis on whole-round squeezecake samples, Holes U1388AU1388C.

\begin{tabular}{|c|c|c|c|c|c|c|c|}
\hline $\begin{array}{l}\text { Core, } \\
\text { section }\end{array}$ & $\begin{array}{l}\text { Depth } \\
\text { (mbsf) }\end{array}$ & $\begin{array}{l}\mathrm{CaCO}_{3} \\
(\mathrm{wt} \%)\end{array}$ & $\begin{array}{c}\text { Inorganic } \\
\text { carbon } \\
\text { (wt\%) }\end{array}$ & $\begin{array}{l}\text { Total } \\
\text { carbon } \\
\text { (wt\%) }\end{array}$ & $\begin{array}{l}\text { Nitrogen } \\
\text { (wt\%) }\end{array}$ & $\begin{array}{l}\text { Organic } \\
\text { carbon } \\
\text { (wt\%) }\end{array}$ & $\mathrm{C} / \mathrm{N}$ \\
\hline \multicolumn{7}{|c|}{ 339-U1388A- } & 4.0 \\
\hline \multicolumn{8}{|c|}{ 339-U1388B- } \\
\hline $4 X-2$ & 28.50 & 29.089 & 3.488 & 3.87 & 0.05 & 0.38 & 7.6 \\
\hline $5 X-C C$ & 36.34 & 26.462 & 3.173 & 3.49 & 0.02 & 0.32 & 16.0 \\
\hline $6 X-2$ & 46.98 & 17.988 & 2.157 & 2.78 & 0.08 & 0.62 & 7.8 \\
\hline $7 X-1$ & 55.34 & 21.064 & 2.526 & 3.28 & 0.09 & 0.75 & 8.3 \\
\hline $9 \mathrm{X}-1$ & 73.61 & 20.974 & 2.515 & 3.27 & 0.08 & 0.76 & 9.5 \\
\hline $10 X-2$ & 84.57 & 29.894 & 3.584 & 4.24 & 0.06 & 0.66 & 11.0 \\
\hline $12 X-4$ & 107.11 & 25.953 & 3.112 & 3.66 & 0.08 & 0.55 & 6.9 \\
\hline $13 X-6$ & 117.93 & 26.657 & 3.196 & 3.48 & 0.06 & 0.28 & 4.7 \\
\hline $14 X-6$ & 129.06 & 24.925 & 2.988 & 3.61 & 0.06 & 0.62 & 10.3 \\
\hline $15 X-6$ & 138.70 & 24.589 & 2.948 & 3.37 & 0.06 & 0.42 & 7.0 \\
\hline $16 X-5$ & 146.83 & 25.835 & 3.097 & 3.65 & 0.08 & 0.55 & 6.9 \\
\hline $18 X-2$ & 160.90 & 24.614 & 2.951 & 3.72 & 0.09 & 0.77 & 8.6 \\
\hline $19 X-6$ & 176.89 & 29.753 & 3.567 & 4.49 & 0.10 & 0.92 & 9.2 \\
\hline $20 X-6$ & 185.57 & 22.484 & 2.696 & 3.21 & 0.09 & 0.51 & 5.7 \\
\hline $21 \mathrm{X}-\mathrm{CC}$ & 188.37 & 23.636 & 2.834 & 3.39 & 0.09 & 0.56 & 6.2 \\
\hline $22 X-1$ & 198.06 & 29.736 & 3.565 & 4.10 & 0.06 & 0.53 & 8.8 \\
\hline $23 X-3$ & 210.75 & 22.389 & 2.684 & 3.35 & 0.11 & 0.67 & 6.1 \\
\hline $24 X-5$ & 223.41 & 20.551 & 2.464 & 3.27 & 0.13 & 0.81 & 6.2 \\
\hline \multicolumn{8}{|c|}{ 339-U1388C- } \\
\hline $3 R-4$ & 220.14 & 20.689 & 2.481 & 3.09 & 0.11 & 0.61 & 5.5 \\
\hline $4 \mathrm{R}-1$ & 224.74 & 22.835 & 2.738 & 3.46 & 0.11 & 0.72 & 6.5 \\
\hline
\end{tabular}


Table T15. Interstitial water major and trace elements, Site U1388.

\begin{tabular}{|c|c|c|c|c|c|c|c|c|c|c|c|c|c|c|c|c|}
\hline $\begin{array}{l}\text { Core, section, } \\
\text { interval (cm) }\end{array}$ & $\begin{array}{l}\text { Depth } \\
\text { (mbsf) }\end{array}$ & $\begin{array}{c}\text { Alkalinity } \\
\text { (meq/L) } \\
\text { TITRA_AUTO }\end{array}$ & $\begin{array}{l}\mathrm{NH}_{4}^{+} \\
(\mu \mathrm{M}) \\
\text { SPEC }\end{array}$ & $\begin{array}{c}\text { B }(\mu \mathrm{M}) \\
208.956 \mathrm{~nm} \\
\text { ICPAES }\end{array}$ & $\begin{array}{c}\mathrm{Ba}(\mu \mathrm{M}) \\
455.403 \mathrm{~nm} \\
\text { ICPAES }\end{array}$ & $\begin{array}{c}\mathrm{Ca}^{2+}(\mathrm{mM}) \\
\mathrm{IC}\end{array}$ & $\begin{array}{l}\text { Cl- }^{-}(\mathrm{mM}) \\
\text { TITRA_AUTO }\end{array}$ & $\begin{array}{c}\mathrm{Fe}(\mu \mathrm{M}) \\
239.563 \mathrm{~nm} \\
\text { ICPAES }\end{array}$ & $\begin{array}{c}\mathrm{Li}(\mu \mathrm{M}) \\
670.784 \mathrm{~nm} \\
\text { ICPAES }\end{array}$ & $\mathrm{Mg}_{\text {IC }}^{2+}(\mathrm{mM})$ & $\begin{array}{l}\mathrm{pH} \\
\text { ISE }\end{array}$ & $\mathrm{K}^{+}(\mathrm{mM})$ & $\begin{array}{c}\mathrm{Si}(\mu \mathrm{M}) \\
288.158 \mathrm{~nm} \\
\text { ICPAES }\end{array}$ & $\begin{array}{l}\mathrm{Na}^{+}(\mathrm{mM}) \\
\text { IC }\end{array}$ & $\begin{array}{c}\mathrm{Sr}(\mu \mathrm{M}) \\
421.552 \\
\mathrm{~nm} \\
\text { ICPAES }\end{array}$ & $\begin{array}{c}\mathrm{SO}_{4}{ }^{2-}(\mathrm{mM}) \\
{ }_{\mathrm{IC}}\end{array}$ \\
\hline $\begin{array}{l}\text { 339-U1388A- } \\
1 \mathrm{H}-2,126-131\end{array}$ & 2.76 & 4.7 & 378 & 490.0 & & 12.6 & 585.6 & 0.8 & 55.3 & 55.5 & 8.2 & 11.9 & 113.5 & 510.8 & 95.5 & 29.3 \\
\hline 339-U1388B- & & & & & & & & & & & & & & & & \\
\hline $6 \mathrm{X}-1,145-150$ & 46.45 & 6.2 & 3863 & 493.5 & 19.7 & 4.5 & 640.8 & 1.7 & 35.0 & 36.4 & 7.8 & 7.4 & 166.8 & 524.0 & 92.1 & 0.0 \\
\hline $9 \mathrm{X}-1,123-128$ & 73.73 & 6.1 & 4585 & 455.8 & 31.8 & 6.7 & 683.3 & 1.4 & 32.8 & 42.2 & 7.8 & 8.1 & 236.1 & 632.7 & 93.2 & 0.0 \\
\hline $10 X-1,146-151$ & 83.56 & 6.6 & 5267 & 461.3 & 37.7 & 5.5 & 663.1 & 0.8 & 40.2 & 38.3 & 7.9 & 7.0 & 347.0 & 566.0 & 101.8 & 0.0 \\
\hline $12 X-4,145-150$ & 107.25 & 6.4 & 6063 & 348.3 & 52.5 & 6.1 & 673.4 & 1.5 & 46.6 & 37.0 & 7.8 & 6.8 & 256.8 & 552.5 & 109.5 & 0.0 \\
\hline $13 X-6,145-150$ & 118.51 & 5.8 & 5913 & 347.1 & 56.9 & 6.6 & 668.6 & 1.9 & 43.3 & 37.4 & 8.0 & 6.8 & 253.8 & 570.4 & 114.5 & 0.0 \\
\hline $14 X-5,145-150$ & 127.85 & 4.9 & 6352 & 329.8 & 52.8 & 6.9 & 684.3 & 1.3 & 38.8 & 37.5 & 8.0 & 6.6 & 179.0 & 578.6 & 112.4 & 0.0 \\
\hline $16 X-5,145-150$ & 146.95 & 4.8 & 7671 & 322.3 & 39.0 & 6.3 & 704.9 & 2.8 & 38.4 & 37.5 & 7.8 & 6.7 & 192.9 & 590.3 & 107.0 & 0.0 \\
\hline $17 X-1,145-150$ & 150.55 & 5.2 & 7555 & 324.7 & 35.0 & 6.7 & 690.6 & 1.2 & 41.8 & 40.6 & 7.8 & 6.5 & 250.7 & 615.8 & 112.6 & 0.0 \\
\hline $18 \mathrm{X}-1,145-150$ & 160.05 & 7.4 & 6701 & 235.7 & 26.7 & 7.7 & 736.2 & 15.6 & 47.4 & 43.4 & 7.7 & 6.1 & 539.6 & 619.0 & 114.5 & 0.0 \\
\hline $19 X-6,125-130$ & 176.95 & 9.2 & 8404 & 233.5 & 22.2 & 7.8 & 750.3 & 4.5 & 58.1 & 44.2 & 7.7 & 6.4 & 646.8 & 634.5 & 113.5 & 0.0 \\
\hline $20 X-5,122-127$ & 185.02 & 8.1 & 8183 & 209.8 & 19.7 & 7.7 & 761.0 & 2.5 & 57.0 & 46.1 & 7.8 & 6.6 & 362.0 & 654.2 & 114.7 & 0.0 \\
\hline $23 X-3,140-145$ & 210.90 & 6.8 & 7989 & 241.3 & 27.6 & 7.3 & 802.8 & 7.8 & 53.1 & 50.0 & 7.9 & 5.7 & 206.6 & 687.5 & 147.5 & 0.0 \\
\hline
\end{tabular}

TITRA_AUTO = automatic titration, SPEC $=$ spectrometer, IC $=$ ion chromatograph, ICPAES $=$ inductively coupled plasma-atomic emission spectrometer, ISE $=$ ion-selective electrode. 
Table T16. Interstitial water oxygen and hydrogen isotopes, Site U1388.

\begin{tabular}{|c|c|c|c|}
\hline $\begin{array}{l}\text { Core, section, } \\
\text { interval }(\mathrm{cm})\end{array}$ & $\begin{array}{l}\text { Depth } \\
\text { (mbsf) }\end{array}$ & $\begin{array}{c}\delta^{18} \mathrm{O} \\
(\%, \mathrm{VSMOW})\end{array}$ & $\begin{array}{c}\delta \mathrm{D} \\
(\% \circ, \text { VSMOW) }\end{array}$ \\
\hline \multicolumn{4}{|l|}{ 339-U1388A- } \\
\hline $1 \mathrm{H}-2,126-131$ & 2.81 & 0.78 & 6.47 \\
\hline \multicolumn{4}{|l|}{ 339-U1388B- } \\
\hline $6 X-1,145-150$ & 46.5 & 1.31 & 9.19 \\
\hline $9 X-1,123-128$ & 73.78 & 1.40 & 8.69 \\
\hline $10 X-1,146-151$ & 83.6 & 1.20 & 8.86 \\
\hline $12 X-4,145-150$ & 107.3 & 1.32 & 8.21 \\
\hline $13 X-6,145-150$ & 118.56 & 1.32 & 7.44 \\
\hline $14 X-5,145-150$ & 127.9 & 1.20 & 7.87 \\
\hline $15 X-5,145-150$ & 137.4 & 1.33 & 8.19 \\
\hline $16 X-5,145-150$ & 148.5 & 1.25 & 8.40 \\
\hline $17 X-1,145-150$ & 150.6 & 1.09 & 7.55 \\
\hline $18 X-1,145-150$ & 160.1 & 1.31 & 7.62 \\
\hline $19 X-6,125-130$ & 177 & 1.41 & 8.09 \\
\hline $20 X-5,122-127$ & 185.07 & 1.06 & 7.38 \\
\hline $23 X-3,140-145$ & 211 & 1.22 & 7.43 \\
\hline
\end{tabular}

VSMOW = Vienna standard mean ocean water. 